\title{
Management of crop water under drought: a review
}

\author{
Gernot Bodner • Alireza Nakhforoosh • Hans-Peter Kaul
}

Accepted: 12 January 2015 / Published online: 4 February 2015

(C) INRA and Springer-Verlag France 2015

\begin{abstract}
Drought is a predominant cause of low yields worldwide. There is an urgent need for more water efficient cropping systems facing large water consumption of irrigated agriculture and high unproductive losses via runoff and evaporation. Identification of yield-limiting constraints in the plant-soil-atmosphere continuum are the key to improved management of plant water stress. Crop ecology provides a systematic approach for this purpose integrating soil hydrology and plant physiology into the context of crop production. We review main climate, soil and plant properties and processes that determine yield in different water-limited environments. From this analysis, management measures for cropping systems under specific drought conditions are derived. Major findings from literature analysis are as follows. (1) Unproductive water losses such as evaporation and runoff increase from continental in-season rainfall climates to storage-dependent winter rainfall climates. Highest losses occur under tropical residual moisture regimes with short intense rainy season. (2) Sites with a climatic dry season require adaptation via phenology and water saving to ensure stable yields. Intermittent droughts can be buffered via the root system, which is still largely underutilised for better stress resistance. (3) At short-term better management options such as mulching and date of seeding allow to adjust cropping systems to site constraints. Adapted cultivars can improve the synchronisation between crop water demand and soil supply. At long term, soil hydraulic and plant physiological constraints can be overcome by changing tillage systems and breeding new varieties with higher stress resistance. (4) Interactions between plant and soil, particularly in the rhizosphere, are a way towards better crop water supply. Targeted management of such plant-soil interactions is still at infancy.
\end{abstract}

G. Bodner $(\bowtie) \cdot$ A. Nakhforoosh $\cdot$ H.-P. Kaul

Department of Crop Sciences, Division of Agronomy, University of

Natural Resources and Life Sciences BOKU Vienna, Konrad

Lorenzstrasse 24, 3430 Tulln an der Donau, Austria

e-mail: gernot.bodner@boku.ac.at
We conclude that understanding site-specific stress hydrology is imperative to select the most efficient measures to mitigate stress. Major progress in future can be expected from crop ecology focussing on the management of complex plant (root)-soil interactions.

Keywords Water stress $\cdot$ Drought resistance Plant-soil interactions - Crop ecology - Root system - Water management

Contents

1. Introduction

2. Subsystems of water flow through the soil-plantatmosphere continuum

2.1 Climate subsystem

2.2 Soil subsystem

2.3 Plant subsystem

2.3.1 Plant properties and processes

2.3.2 Plant resistance to drought

2.4 Subsystem interactions and feedbacks

3. Efficiency of management measures in different hydrological regimes

3.1. A framework for efficient agricultural water use

3.2 Management measures

3.2.1 Soil-related measures

3.2.2 Plant-related measures

4. Conclusions

References

\section{Introduction}

Water scarcity is considered a key threat for the twenty-first century (UNESCO 2012). FAO defines drylands as areas 
where water shortage constrains the length of the growing season below 179 days (FAO 2000); this includes regions classified climatically as arid, semi-arid and dry subhumid. On average, $40 \%$ of the world's land surface are drylands, ranging from $89 \%$ in Oceania to $24 \%$ in Europe. Cultivated land makes up $25 \%$ of total dryland area, decreasing from $47 \%$ in dry subhumid to $0.6 \%$ in hyper-arid regions. Currently, $36 \%$ of the world population is living in regions where water is a limited resource (Safriel et al. 2005). Agriculture is by large the dominant user of fresh water, except for Europe (22\%) and North America (38 \%), accounting for up to $90 \%$ of total water consumption in some regions (FAO 2004b; Hoekstra and Mekonnen 2012). When projecting the current trend of global annual water usage, it will rise to 6.9 trillion cubic metres by 2030 , being $40 \%$ more than can be provided by available water supplies (Gilbert 2010). Sposito (2013) highlighted that both land conversion for crop cultivation as well as water use for croplands are approaching their planetary limits. Therefore, he pointed to the need for new approaches to enhance water productivity by making use of plant-soil interactions.

Crop ecology studies the environmental properties and processes in the soil-plant-atmosphere continuum (SPAC) that determine the productivity of a cropping system, and how the use of available growth factors can be optimised (e.g. Swaminathan 2006; Connor et al. 2011). In the particular context of water management, crop ecology links the analysis of (1) the hydrological situation driven by climate and soil and (2) the physiological response of the plant in order to provide management strategies for optimum water supply to and efficient use by the crop.

Cropping systems are ecosystems with strong anthropogenic forcing. There are two main distinctions between a cropping system and a natural ecosystem. First, the variable of interest is clearly focussed on yield in a cropping system, while in a natural ecosystem, particularly in a stress environment, survival and reproductive success could actually contradict maximum biomass productivity. This has strong implications as easily exemplified in the context of drought resistance: A range of resistance mechanisms (e.g. small leaf surface, membrane stability) were described from natural vegetation where they allow survival and reproduction under harsh drought stress. Although highly effective, they are irrelevant for a water-efficient cropping system because of their incompatibility with high yields. Crop production requires a minimum site productivity, while survival mechanisms of xerophytic vegetation confer superior growth mostly under stress beyond the limit of rainfed agriculture (Blum 2005). Second, the key interest of crop ecology is to understand which properties and processes in the natural system can be most efficiently manipulated for a better performance of crops within the given environmental constraints (e.g. climate, soil texture). Contrary to an ecological approach to natural ecosystems, here, system components are conceived as changeable by human activity. However, crop ecology is still situated in the general field of ecology: The cropping system is not a technical environment without natural constraints, but an ecosystem that requires profound understanding of its physical, chemical, and biological functioning to allow sustainable productivity.

Larcher (1994) provides data of net primary productivity (NPP) of different ecosystems. Cropping systems $\left(0.65 \mathrm{~kg} \mathrm{~m}^{-2} \mathrm{a}^{-1}\right)$ are in the range of sclerophyll savanna vegetation $\left(0.7-0.9 \mathrm{~kg} \mathrm{~m}^{-2} \mathrm{a}^{-1}\right)$. There is a tight relation of NPP and leaf area index where both cropping systems and savanna vegetation have similar values $\left(4 \mathrm{~m}^{2} \mathrm{~m}^{-2}\right)$. This suggests that, in many environments, agricultural productivity is not primarily limited by natural boundaries, but by an inefficient use of available growth factors such as light, water, and nutrients. Rockström et al. (2007) give an example how yield levels in semi-arid sub-Saharan Africa could be doubled by simply reducing the current level of high runoff and evaporation losses. This points to the key importance of detailed ecological understanding of cropping systems to obtain an optimum use of available growth factors.

With an overall focus on high crop productivity in waterlimited ecosystems, the key questions from a crop ecological point of view can be stated as follows: How much improvement in crop water use is feasible, and what is the most efficient management change to achieve it within the site-specific environmental constraints? The principal objective of this review is to establish a relation between drought regime and efficient crop water management measures. Tardieu (2012) stated that any trait can confer drought resistance to a crop; it is just a matter of designing the right drought scenario. It is therefore imperative to understand the specific ecology of drought in a region to design an efficient cropping system. The second objective of this review is to identify areas of plant water use that are still poorly understood by crop sciences and therefore underutilised in cropping system management. In this context, we put an emphasis on dynamic plant-soil interactions, which special regard on the root zone (Fig. 1), and discuss challenges how to bridge the gap between scientific advances at small scales of observation to the overall cropping system.

With this work, we intend to promote the integration of soil hydrology and plant ecophysiology into an agronomic framework that strives for measures to increase crop productivity in water-limited environments and to reveal the key role of root research as a still largely unexploited field with high potential to achieve more resource efficient production systems.

\section{Subsystems of water flow through the soil-plant- atmosphere continuum}

This study deals with green water dynamics in agro-ecosystems. Green water is defined as rainfall stored in the soil and 


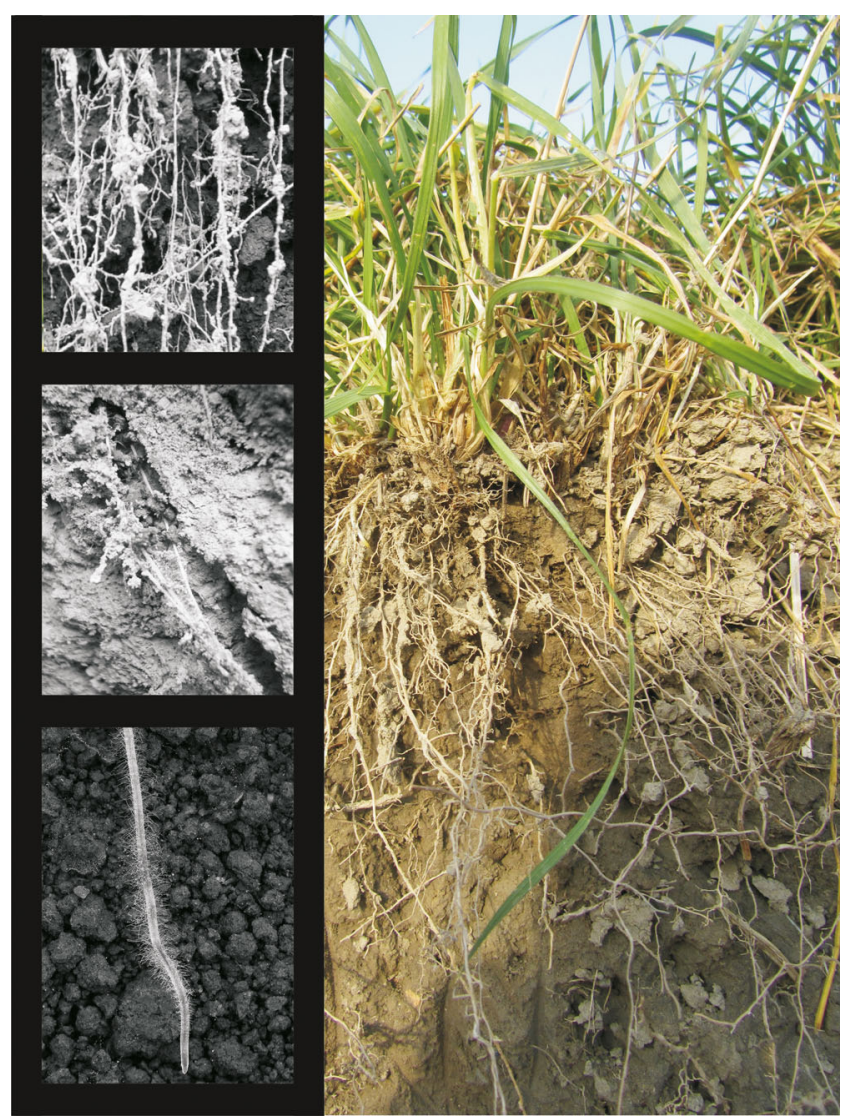

Fig. 1 The root zone as dynamic interface between plant and soil plays a key role in crop water supply. Many processes are still poorly understood, and therefore, development of new agronomic measures for root zone management is a strategic challenge to mitigate water stress in cropping systems directly used and evaporated by non-irrigated agriculture, pastures and forests, while blue water is equivalent to fresh water from surface and groundwater bodies (FAO 2003). We neither consider the groundwater subsystem, with possible inputs to the root zone via capillary rise, nor additional water supply via irrigation. Figure 2 gives an overview of the three subsystems that determine the water relations in the soil-plant-atmosphere continuum (SPAC) and their main properties.

\subsection{Climate subsystem}

The climate is the main driver that shapes all other subsystems in the SPAC. In the context of crop management, it is important to distinguish between drylands and drought. Drylands are regions within the climatic categories of dry sub-humid to hyper-arid where generally rainfall is less than evapotranspiration (FAO 2004a). Contrary to dry climate, drought is defined as a more or less short period of abnormally dry weather where the lack of precipitation causes serious hydrological imbalance (World Meteorological Organization 1992). While cropping systems are generally better adapted to regular seasonal stress periods in dry climates (e.g. coincidence of growing and rainy season, fallow year for water storage), intermittent drought constitutes an unpredictable risk of production loss for rainfed systems (Serraj et al. 2003). Mishra and Singh (2010) pointed to the positive correlation between dry climatic conditions (low annual rainfall) and drought (high inter-annual variability). Thus, with higher climatic dryness also the risk of abnormal drought stress periods increases. Global change is expected to further increase weather
Fig. 2 Subsystems of the SPAC, their key properties and processes determining water relations in an agro-ecosystem. Crop management can target subsystem properties (e.g. soil humus content), processes between subsystems (e.g. reduce evaporation), as well as feedback loops (e.g. root-induced soil structure stabilisation)

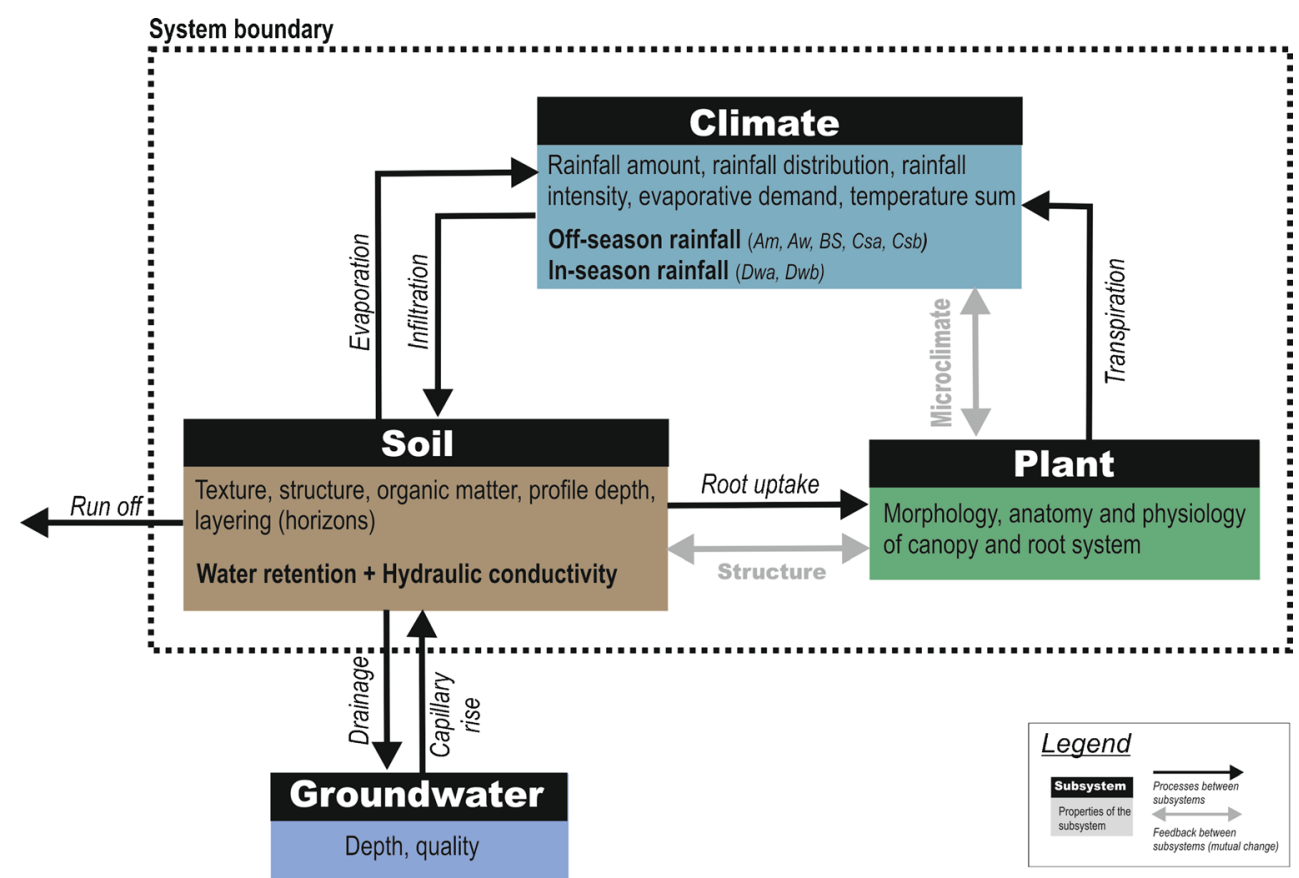


extremes and thereby climatic uncertainty (Lehner et al. 2006; Sheffield and Wood 2008).

For crop production, drought impact depends on three main characteristics being severity, length and timing of drought (Dracup et al. 1980). These characteristics are incorporated into the delineation of CIMMYT mega-environments underlying their drought resistance breeding programmes. They coarsely distinguish between early season, late season and continuous drought (residual moisture) regions, which require specific traits for stress adaptation (van Ginkel et al. 1998). With increasing length and severity of the stress period, soil storage and crop resistance determine the suitability of a site for rainfed crop production. Thus, all measures enhancing the buffer capacity of the soil subsystem against rainfall deficit and the plasticity of the plant subsystem to respond to water stress are of key importance for dry rainfed cropping systems. The relation between rainfall supply and soil storage capacity is the most important characteristic for a stress environment (Fig. 3). From the point of view of crop water management, the related ecohydrological differentiation between off-season rainfall systems with dominant plant water supply from stored soil water vs. in-season rainfall systems with main rain water input during the crop growing period is of fundamental importance to derive adapted water management and breeding strategies (Rodriguez-Iturbe et al. 2001).

\subsection{Soil subsystem}

Most primary factors of soil formation (climate, parent material, landscape relief, time) and resulting basic soil properties with relevance to soil water supply, such as texture and profile depth, are beyond the influence of management. Still, the secondary structuring of the soil fabric involves dynamic biotic and abiotic processes that respond sensitively to management.

At the field scale, the key soil water flow processes are captured by the water balance. Each component of the water balance can be analysed in terms of underlying primary (unchangeable) and secondary (manageable) soil properties. The first process in the field water cycle is rainfall infiltration. Hillel (1980) gives five factors controlling infiltrability, i.e. time from the onset of rain, initial water content, soil hydraulic conductivity, soil surface conditions (porous vs. crusted) and impeding layers in the soil profile. Management-driven soil properties conditioning infiltrability are macroporosity and pore continuity (e.g. Shaver et al. 2002; Lipiec et al. 2006), plant and mulch coverage (e.g. Stern et al. 1991; Bodner et al. 2008), stability of surface aggregate structure (e.g. Barthes and Roose 2002; Lado et al. 2004) and surface roughness (e.g. Darboux and Huang 2005; Lampurlanés and CanteroMartínez 2006). Runoff generation upon rainfall intensity exceeding soil infiltrability implies that surface soil is at or near saturation. Therefore, high drainage capacity via enhanced
Fig. 3 Interrelation of climate and soil subsystems for plant water supply in a rainfed cropping system. In supply-driven ecosystems, plant water supply depends on in-season rainfall, while crop performance in storagedriven systems is strongly linked to soil retention of rainwater fallen before the time of maximum crop demand

inter-macroaggregate porosity is a central target of soil management at erosion prone sites. This implies management systems that supply and conserve the relevant biological agents (roots, earthworms) underlying the formation and stabilisation of these coarse structural elements (Hangen et al. 2002; Capowiez et al. 2009).

Once infiltrated into the soil, water transport (deep percolation, flow to roots and to soil surface) occurs mainly under unsaturated conditions. A main target of agricultural management is to ensure a high volume of stored soil water available for plant uptake. Commonly, an important role in water storage has been attributed to soil organic matter (Hudson 1994). Loveland and Webb (2003), however, reported that soils with higher organic matter had lower bulk density, which decreased plant available water while increasing air filled porosity. Rawls et al. (2003) demonstrated that the organic matter effect on water availability is texture dependent. In most coarsely textured soils of their investigation, plant available water increased with organic matter content, while in finer textured soils, an increase in water content at field capacity was only found at very high organic matter levels. On a smaller scale, Carminati et al. $(2010,2011)$ recently demonstrated a distinct organic carbon effect in the rhizosphere via mucilage increasing water availability around roots. Plant water availability, however, is not only a function of soil storage capacity but also of soil profile depth. While soil genesis (age, weathering intensity, relief) results in a distinct profile depth, plant root growth essentially determines the effective profile depth to be considered for plant water use. Kell (2011) pointed to the unexploited potential of breeding for deeper rooted crops to substantially improve resource uptake efficiency in deep rooted cropping systems. Deeper root systems can be achieved either by cultivar selection (Wasson et al. 2014), tillage system (Pietola 2005) or crop stand establishment (Sharratt and McWilliams 2005).

A process tightly related to soil water storage is seepage water loss by drainage below the root zone towards the groundwater. Together with runoff, drainage from low storage soils can account for 40-50\% of total losses of incoming rainfall (Wallace 2000). Beyond pedogenetic constraints (texture, profile depth), crop management can mitigate high drainage losses by increasing organic carbon supply and optimising soil conditions for root growth.

Soil evaporation is a dominant loss component in many agro-ecosystems, accounting for up to $35 \%$ of total water losses (Wallace 2000; Liu et al. 2002) and between 30 and 


\section{High supply}

Sufficient rainfall amount

Favourable distribution

Intermediate evaporative demand
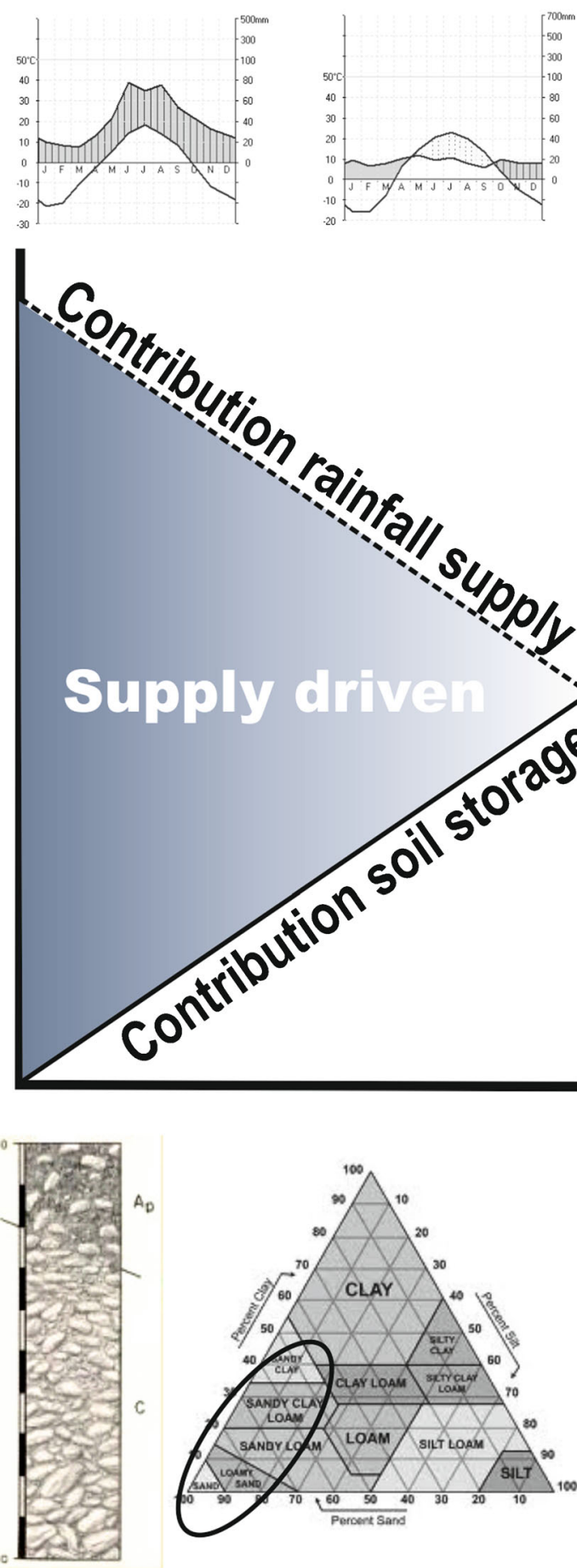

Shallow profile

Sand dominated texture

High stone content

\section{Low supply}

Insufficient rainfall amount Unfavourable distribution

High evaporative demand

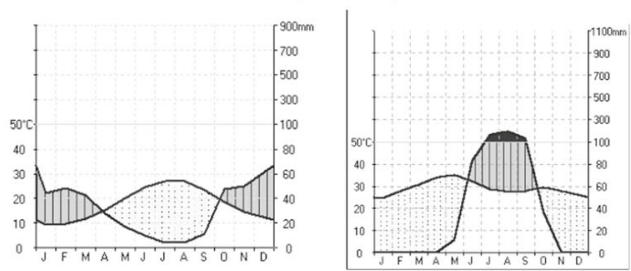

\section{Low storage capacity}
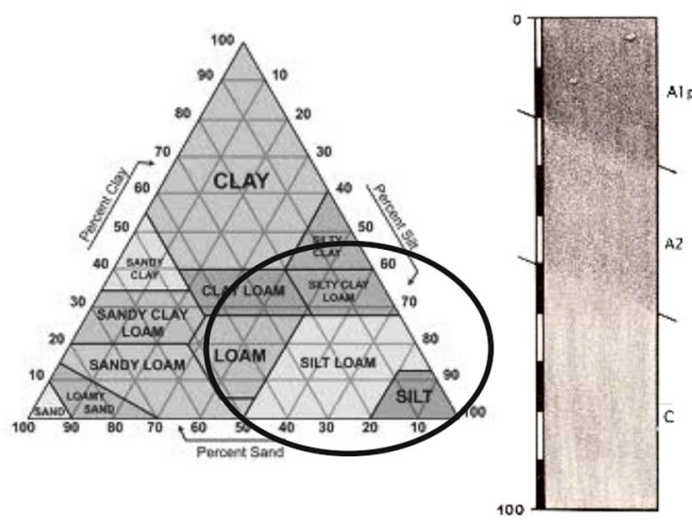

Deep profile

Silt dominated texture

High organic carbon 
$60 \%$ of total evapotranspiration (Siddique et al. 1990a; Debaeke and Aboudrare 2004). The amount of evaporation losses depends on climate (evaporative demand) and soil conditions (surface wetness, soil hydraulic conductivity; Hillel 1980; Gregory et al. 2000). Soil cover (crops, mulch) alter the radiation balance at the soil surface, thereby reducing evaporation. However, agricultural crops provide soil surface cover only during a relatively short time of the year, leaving a bare soil surface for up to 8 months (Allen et al. 1998). Depending on early vigour and stand density, there are also substantial evaporation losses during early growth stages until crops achieve full coverage (Eastham et al. 1999; Richards et al. 2002; Passioura 2002). Additionally drought stress results in sparse canopies further increasing evaporation losses during the growing season (Allen 1990). Beside canopy effect, plants with intensive root density near surface compete with evaporation for water in the upper 15-20 cm soil layer (Allen et al. 1998; Rodriguez-Iturbe et al. 1999; Bodner et al. 2007).

The importance of the individual loss terms in the overall field water cycle depends on the interplay between climate (rainfall supply vs. evaporative demand), landscape (relief), soil (storage capacity) and vegetation (timing of cropping season). Figure 4 shows the approximate timing and extent of mayor loss terms for three different drought scenarios characteristic for main regions of dryland agriculture.

Supply-driven conditions are typically found in semi-arid continental climates of the temperate zone where growth potential is mainly dependent on incoming rainfall during the vegetation period. Rainfall distribution ranges from evenly

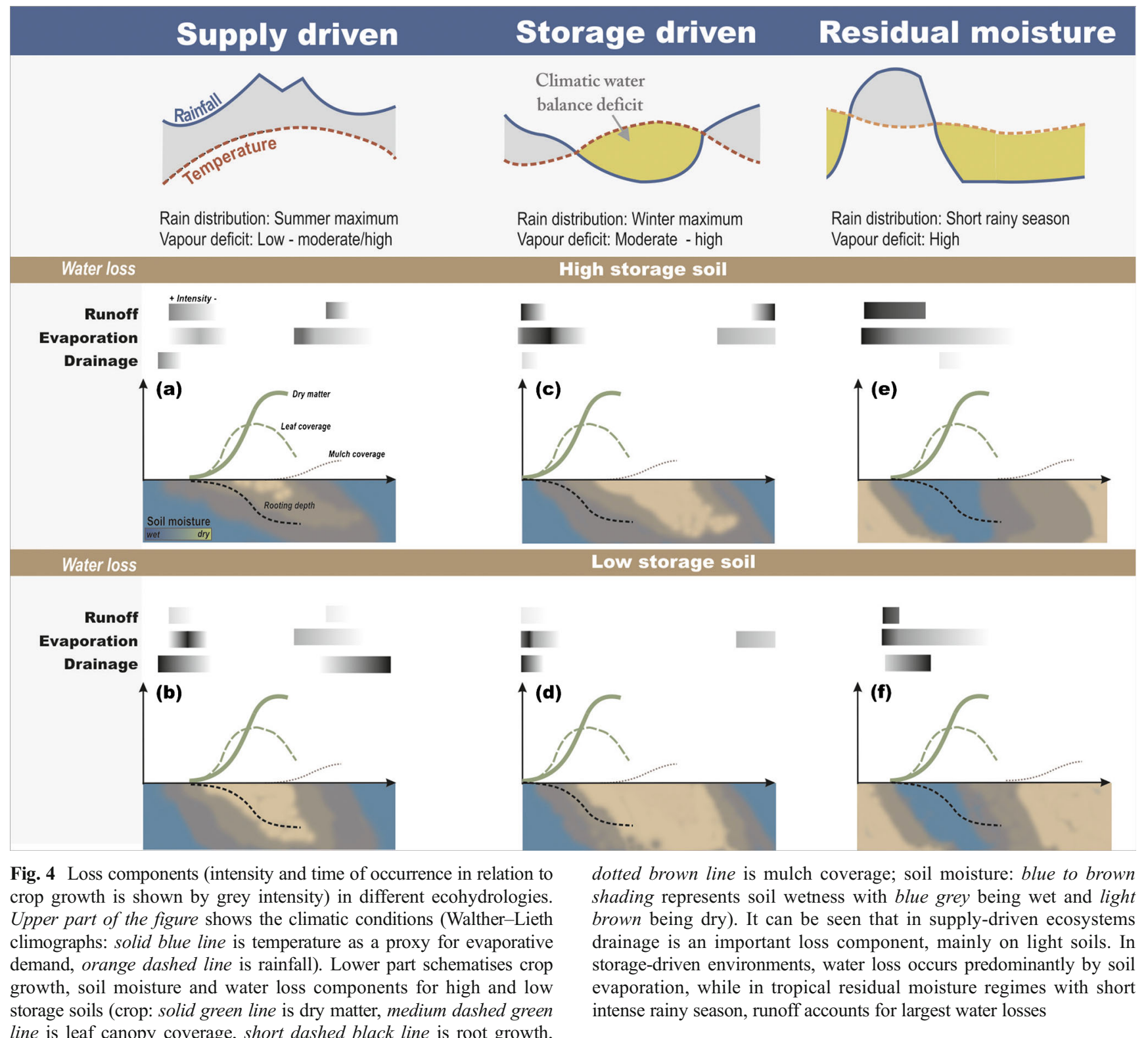


distributed (Dfa according to Köppen classification) to summer maxima (Dwa), while evaporative demand shows strong seasonality with moderate to high values in summer and low values in winter. The cropping season is frequently constraint by low temperatures in winter. Dependence on incoming rainfall is further enforced at sites with low soil storage capacity.

In storage-driven environments, crop growth depends on soil moisture supplied by rainfall previous to the cropping season. Dependence of growth potential on stored water increases with (i) shortening of the rainy season and (ii) overlapping of the cropping period with the dry season. Mediterranean ecosystems are storage-driven winter rain climates with water shortage increasing towards the late (generative) stage of crop growth when rainfall is largely missing and evaporative demand approaches a summer peak (Csa, Csb and Dsa climates). In the framework of CIMMYT target environments for drought stress breeding, this type of environment corresponds to mega-environment ME4A (van Ginkel et al. 1998).

Tropical and subtropical dry climates are characterised by a sharp separation of rainy and dry seasons with high temperatures and evaporative demand over the whole year (Aw and BS climates). After the rainy season, crop growth exclusively depends on residual moisture that was stored in soil during the rainy period. The dry season in tropical and subtropical environments thereby constitutes an extreme case of water storage dependence of crops. Within the CIMMYT framework, this type of situation is classified as mega-environment ME4C with continuous drought following monsoon.

The main advantage of supply-driven systems is the coincidence of crop water use and rainfall supply. This implies that the soil surface is frequently covered by vegetation during the summer peak rainfalls, thereby reducing runoff. Main losses are due to evaporation in case of early harvested crops such as cereals, rapeseed or legumes with subsequently bare soil during the wet and warm summer to early autumn (Fig. 4a). Low storage soils are prone to high drainage losses during the vegetation free period with low evaporation in late autumn and spring, particularly upon snow melting after winter (Fig. 4b).

In storage-driven winter rainfall ecosystems, evaporation is the dominant loss component (Fig. 4c). As rainfall gradually decreases towards summer, the soil surface is still frequently rewetted at times of incomplete crop coverage and increasing evaporative demand. Soils with high storage capacity together with small rainfall events on dry soil restrict infiltration depth. Thereby, only the soil surface is rewetted and water is prone to evaporation. After the end of the crop cycle at the onset of the summer dry period, evaporation decreases due to intense surface drying until the onset of winter rain. Although drainage is a relevant loss component for low storage soils (Fig. 4d), it is smaller than in temperate climates due to the strong depletion of profile moisture during the dry summer season and higher evaporative demand during the rainy winter season (Asseng et al. 2000). Runoff losses are mainly a function of geomorphology and land use (Yang et al. 2003). However, lack of plant cover after the summer season can result in high runoff losses in case of intense rainfall on a bare soil surfaces at the onset of rainy season.

Such high rainfall intensities are even more typically found in tropical and subtropical residual moisture hydrologies with short rainy season (e.g. monsoon climate; Colin et al. 2010), contributing to global peak soil degradation rates due to erosion in Asia (Scherr and Yadav 1996). Thereby, runoff due to insufficient soil infiltrability is a main loss component in tropical and subtropical residual moisture ecosystems (Fig. 4 e, f). In addition, high evaporation losses until complete crop cover are due to high temperatures and evaporative demand over the whole year. Evaporation then decreases rapidly with the onset of the dry season upon intense drying of surface soil layers. In residual moisture agro-ecosystems, crops grown during the rainy season can seriously suffer from intermittent drought, which builds up quickly due to the high evaporative demand. When terminal growth stages extend to the dry season or a second post-rainy season cropping cycle is included, crop performance depends mostly on water stored in the soil. Such conditions therefore hardly allow any crop production on low storage soil without supplementary irrigation. Under tropical and subtropical residual moisture conditions, therefore, water losses during the rainy season, i.e. runoff for low infiltrability soils and deep drainage for low storage soils, are detrimental for growth and yield formation due to the high climatic water demand and the unfavorable rainfall distribution.

\subsection{Plant subsystem}

The plant subsystem is a particularly complex part of the SPAC due to its morphological plasticity and physiological reactivity. There are numerous comprehensive reviews on plant-water relations (e.g. Slayter 1967; Lösch 1995; Kramer and Boyer 1995; Kirkham 2005; Jones et al. 2008; Nobel 2009; Passioura 2010; Asbjornsen et al. 2011). Here, we only give a short overview of main properties and processes as a basis to understand the relevant traits in crop stress response that might be targeted by management under different hydrological conditions.

\subsubsection{Plant properties and processes}

Water transport between two points in the SPAC is described by (e.g. Maseda and Fernández 2006)

$F_{\mathrm{H}}=-k_{\mathrm{H}(\Psi)} \Delta \Psi_{\mathrm{W}}$

where $F_{\mathrm{H}}$ is volumetric flow per unit time, the proportionality factor is hydraulic conductance $k_{\mathrm{H}}$, and $\Delta \Psi_{\mathrm{W}}$ is the difference 
in water potential driving the flow. Thus, transpiration flow is determined by the water potential drop between rooted soil and air as well as a series of biological valves with variable conductance/resistance. These resistances lead to the main plant properties involved in its adaptation to water shortage.

Several electrical analogue models (Kirkham 2005) have been developed to study how plants regulate gas exchange while avoiding hydraulic failure (Sperry et al. 1998; Tuzet et al. 2003). The components of resistance/conductance constitute the hydraulic architecture of plants, i.e. the structural properties regulating water flow. The first resistance to transpiration is soil hydraulic conductivity that determines water transport velocity between bulk soil and the root surface. The classical model of Gardner (1960) reveals how plants with high root density reduce the inter-root water transport distance and thereby facilitate radial water flow to the root surface. While root length densities between 0.5 and $1.0 \mathrm{~cm} \mathrm{~cm}^{-3}$ are considered sufficient to meet plant demand in moist soil (de Willigen et al. 2000), high root surface area density is required to overcome the increasing hydraulic resistance in drying soil. Drying soil induces increased assimilate allocation to the root and modified carbon investment inside the root system to increase the uptake surface (root/shoot ratio, specific root length, root tissue density; e.g. Huang and Fry 1998; Ryser 2006; Lynch 2013), and it causes direct growth towards moist layers (hydrotropism; Eapen et al. 2005) while sustaining root elongation by osmotic adjustment (Westgate and Boyer 1985; Hsiao and Xu 2000). Root hairs and mycorrhiza contribute to further increase the uptake surface and also penetrate fine pores inaccessible to root axes (Allen 2007; Brown et al. 2012). Furthermore the accumulation of organic compounds, i.e. mucilage, around roots changes rhizosphere hydraulic properties thereby enhancing water availability (Carminati et al. 2011). Hydraulic resistance between root surface and rhizosphere soil is highly dynamic involving variable hydraulic behaviour of dry and wet mucilage as well as root shrinkage and air gap formation that are functionally related to avoid water loss from roots - which, contrary to leaves, do not have a protective cuticle - into dry soil (Carminati et al. 2009).

Once water has moved towards the root surface, flow towards the xylem has to overcome root radial resistance. Steudle (2000) presented a composite transport model that accounts for the distribution of radial water flow between the low resistance apoplastic and the high resistance symplastic and transcellular pathways. Root age and water stress increase apoplastic barriers, thereby reducing the contribution of the passive apoplastic (hydraulic) and enhancing the active cell-to-cell (osmotic) pathways. Beside substances blocking the apoplastic pathway, i.e. suberin lamellae and Casparian band, anatomical differences such as root cortex thickness and structure determine root radial resistance (Steudle and Peterson 1998; Rieger and Litvin 1999). An important regulatory element of root radial resistance with short- term response to water stress are aquaporins, i.e. specialised water channel proteins in cell membranes that significantly reduce the resistance of the cell-to-cell pathway (Lavot and Maurel 2002; Maurel et al. 2008).

In the mature root system and at a certain distance from the tip, xylem vessels acting as transport pipes (Tron et al. 2012) for axial flow towards the stem exert only minor resistance (Doussan et al. 1998). Water transport in the stem xylem has long been studied in relation to the cohesion-tension theory (Tyree 1997). Long distance water transport in the xylem is vulnerable to cavitation and embolism, which increase the resistance to flow (Tyree and Sperry 1989). Species differences in cavitation vulnerability may be related to the degree of stomata control, i.e. iso- versus anisohydric species (Tardieu and Simonneau 1998), differences in xylem structure (Sperry 2003; Choat et al. 2003) and xylem embolism repair mechanisms (Zwieniecki and Holbrook 2009).

Transpiration of water at the leaf implies a phase change from the liquid to gas phase, which takes place in the substomatal cavities of the leaf. There are two important resistances in series, i.e. stomata and boundary layer resistance. Stomata resistance underlies a complex regulatory pathway involving hormone-mediated feed forward and hydraulic feedback mechanisms driven by various environmental stimuli (e.g. Zeiger et al. 1987; Schulze 1994; Tardieu and Davies 1993; Dodd 2013). Boundary layer resistance controls diffusive vapour flux from stomata to the surrounding atmosphere. The thickness of the air boundary layer depends on single leaf size and morphology, microclimate within the crop canopy and wind speed (Schuepp 1993).

Sperry (2004) resumed his findings on the evolution of overall plant hydraulic architecture stating that maximising gas exchange means operating at the edge of dysfunction. Ontologically leaf area/root area ratio constitutes the fundamental whole plant morphological adaptation to equilibrate demand and supply, while on shorter time scales, the dynamic root to leaf level resistances regulate maximisation of $\mathrm{CO}_{2}$ intake without risking complete hydraulic failure (Sperry et al. 2002; Maseda and Fernández 2006).

Figure 5 gives an overview of the temporal sequence of major physiological and morphological effects of water stress, which are frequently monitored in stress response studies.

Physiological effects of water shortage are mostly shortterm responses, while morphological changes provide adaptation at a longer, ontological time scale (Maseda and Fernández 2006). An immediate effect of water shortage is the reduction of turgor pressure resulting in a proportional decrease in cell expansive growth dependent on concomitant changes in cellwall extensibility (Lockhart 1965; Cosgrove 1993). Onset and extent of stomata closure and stomata limitation to $\mathrm{CO}_{2}$ assimilation under stress depend on the safety margin of species: Isohydric plants (e.g. maize, pea, lupine) operate at high safety margins with tight stomata control of leaf water potential, 


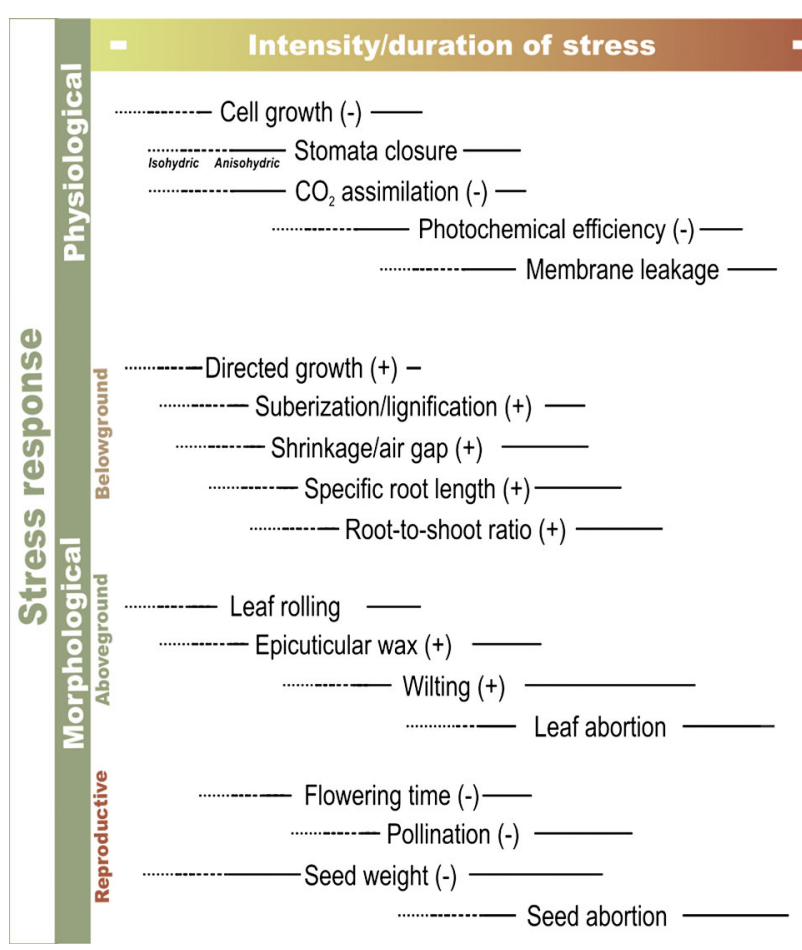

Fig. 5 Physiological and morphological responses to increasing stress intensity/duration ( - shows downregulation/damage, + indicates upregulation; sources: Hsiao, 1973; Chavez, 1991; Hsiao and Xu, 2000; Flexas and Medrano, 2002; Farooq et al., 2009b). Physiological ensures rapid (minutes-days) stress response to avoid damage of plant metabolism. Morphological change allows medium- (weeks) to longterm (ontological) adaptation

often mediated by preventive closure via chemical root signals (Davies and Zhang 1991; Comstock 2002). In anisohydric plants (e.g. wheat, barley, sunflower, soybean), leaf water potential fluctuates significantly with soil water potential and evaporative demand, and stomata only provide a coarse control (Tardieu and Simonneau 1998). Isohydric behaviour can be considered a conservative strategy (high safety at lower $\mathrm{CO}_{2}$ assimilation potential), while anisohydric behaviour implies a growth maximisation strategy at high risk of hydraulic failure (xylem embolism). Although there are different views, most authors consider stomatal limitation of photosynthesis as early drought response, while photochemical limitations (RuBP regeneration, ATP synthesis) only occur at higher stress levels (Flexas and Medrano 2002; Chaves et al. 2003). Prolonged and/or intense water deficit finally decreases cell membrane stability leading to irreversible damage. Electrolyte leakage under osmotically induced stress can be used as an easy method to evaluate differences in membrane stability (e.g. Blum and Ebercon 1981; Tripathy et al. 2000; Bajji et al. 2002).

Water shortage also induces several changes in plant morphology, which act at a longer time scale (weeks to ontology). Compared to physiological studies, morphological studies often do not monitor exactly the stress level (leaf water potential, relative water content) experienced by the plant at the onset of a given response. Furthermore, morphological responses generally imply longer time scales with more variable stress intensity cumulating over parts of the plant phenological development. Therefore, the relation between stress intensity and morphological response is more difficult to determine. For the root zone, it is particularly challenging to establish a clear hierarchy among responses according to stress severity. An increase in root/shoot ratio was frequently observed in stressed plants (e.g. Siddique et al. 1990b; Karcher et al. 2008). In addition, maximum rooting depth constitutes a key morphological adaptation during plant evolution as revealed by the global relation between precipitation and mean rooting depth (Schenk and Jackson 2002). Increase in specific root length under water shortage expresses a change in carbon allocation to fine axes to better exploit soil water resources (Huang and Fry 1998; Ryser 2006).

Changes in leaf surface are functionally related to minimisation of the evaporating surface. Leaf rolling is a transient morphological expression of reduced turgor (e.g. O’Toole and Cruz 1980; Kadioglu et al. 2012). Epicuticular waxes on the leaf surface minimise non-stomatal transpiration and enhance photoprotection (Shepherd and Wynne Griffiths 2006; Samuels et al. 2008). Waxy layers synthetisation can occur within a few days as short time stress response (Premachandra et al. 1991). At increasing stress levels, wilting leads to accelerated senescence of older leaves and leaf abortion, often related to remobilisation of carbohydrates and nutrients to younger tissues or generative sinks (Munné-Bosch and Alegre 2004). The model of Maseda and Fernández (2006) predicts that maintenance of transpiration flow in anisohydric plants requires adjustments under prolonged stress via down-regulation of their water demand by reducing leaf area. Leaf water potential maintaining isohydric species, instead, are expected to keep more of their leaf area (or keep it longer) than anisohydric ones. The need to reduce leaf area by anisohydric species, however, may be lessened if the extra carbon they gain via their leaf-level response allows root access to additional water resources.

Flowering is the most vulnerable stage for drought injury (Farooq et al. 2012). Shortening of flowering time (e.g. Worland 1996; Campos et al. 2004), inhibited pollination or seed abortion leading to reduced kernel number per ear/pod (e.g. Herrero and Johnson 1981; Ekanayake et al. 1989; Gan et al. 2004), as well as low single grain weight due to bad grain filling significantly reduce the sink capacity of grains and impair overall crop yield (e.g. Bolaños and Edmeades 1993; Blum 1998; Gooding et al. 2003).

\subsubsection{Plant resistance to drought}

The single properties and processes characterising plant water relations described above are the fundaments for a 
comprehensive understanding of drought resistance in agricultural crops. The classical scheme of Levitt reveals the main drought resistance strategies in natural vegetation communities (Levitt 1980). Figure 6 resumes Levitt's scheme with a contextualisation for agricultural crop production.

Drought resistance in natural vegetation is an evolution towards ensuring of reproductive success. In agricultural species, success is tightly bound to productivity, i.e. maximisation of biomass and/or grain quantity. This implies that adequate strategies of drought resistance differ.

Blum $(2005,2009)$ demonstrated that yield compatible drought resistance strategies for agricultural species avoid tissue dehydration, particularly by effective use of water, while drought tolerance in a strict sense, i.e. physiological functioning under low tissue water potential, is less relevant due to the immediate reduction of growth when turgor pressure decreases. Yield improvement by drought resistance mechanisms depends strongly on the drought regime (van Ginkel et al. 1998; Blum 2011; Tardieu 2012) Phenological adaptation (drought escape) by early maturity, e.g. might cost vegetation time in early drought environments, while being effective in summer-dry regions. Dehydration avoidance by "water saving" might result in suboptimal use of available water, while in other situations, a "conservative" water use may save water for grain filling and yield formation (Mori et al. 2011). Figure 7 shows the potential role of different stress resistance strategies under the three distinctive stress regimes described in Section 3.2 (cf. Fig. 4).

Crop growth rate integrates the basic physiological, i.e. net assimilation rate (NAR) and morphological, i.e. leaf area index (LAI) characteristics constituting a distinct cumulative growth pattern. Climate, i.e. rainfall vs. evaporative demand; soil, i.e. storage capacity; and rooting, i.e. depth and penetration rate, commonly determine plant water availability during the cropping period.
Fig. 7 Stress response and expected growth impact under different ecohydrologies. Upper part of the figure shows climatic conditions (Walther-Lieth climographs: solid blue line is rainfall, short dashed orange line is temperature as a proxy for evaporative demand). Lower part of the figure shows related soil moisture (blue-brown area) and crop performance (lines) for different drought resistance strategies. Solid line (light green for dry matter growth, dark green for crop growth rate) represents a standard crop; short dashed line shows the expected shift for a drought resistant crop at the respective resistance strategy; for water spending, two rooting strategies and corresponding aboveground response are considered (short dashed for quick root depth penetration, dashed-dotted for high rooting depth). Soil water availability is represented by blue-brown shading (blue for wet and light brown for dry soil). Stress levels are given by horizontal bars (bar length for duration, bar colour for intensity with white showing no stress and black showing high stress). Stress is lowest in supply-driven regimes $(\mathbf{a}-\mathbf{c})$. Highest stress occurs in tropical/subtropical residual moisture regimes $(\mathbf{g}-\mathbf{i})$ where water saving is required to avoid high generative stress (h). When stored subsoil water is available, deep rooting effectively alleviates stress, particularly under summer dry storagedriven moisture regimes (f)

Supply-driven semi-arid continental climates in the temperate zone have a favourable rainfall distribution with high percentage of precipitation during the vegetation period. Intermittent periods of water stress can occur during spring (early drought) and summer (terminal drought; e.g. Łabędzki 2007; Potop and Soukup 2009; Potop et al. 2009; Potop et al. 2010). Compared to Mediterranean and tropical/subtropical dry climates, stress is mostly of short duration and intermediate severity only. Figure $7 \mathrm{a}-\mathrm{c}$ shows the role of the three main drought response strategies (escape, avoidance via water saving and avoidance via water spending; cf. Fig. 6) under supply-driven continental conditions for rainfed crops with early summer harvest such as cereals, rapeseed and pea. Crops with longer vegetation time such as sugar beet, maize, sunflower and potato growing until autumn will be discussed shortly afterwards.

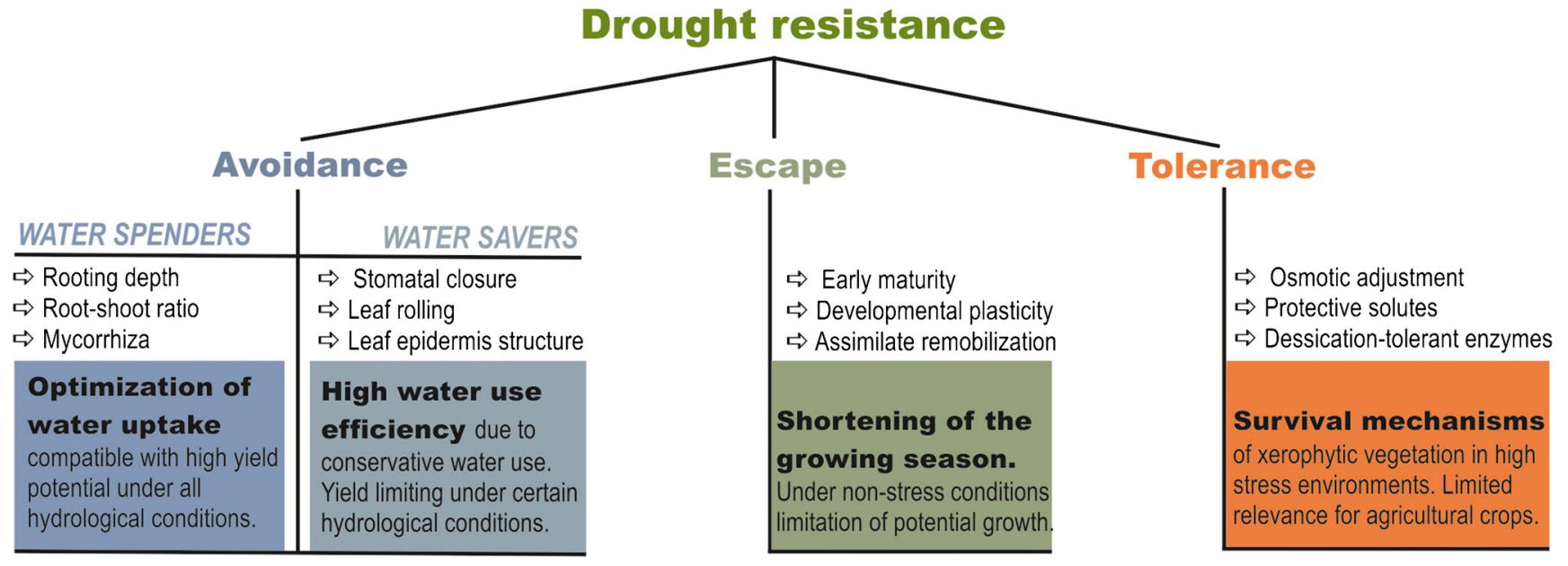

Fig. 6 Drought resistance according to Levitt (1980). Different resistance strategies, examples for corresponding adaptive traits and their potential use/ limitation for agricultural crops. Drought avoidance via efficient water uptake is most compatible with high crop yields 


\section{Supply driven}

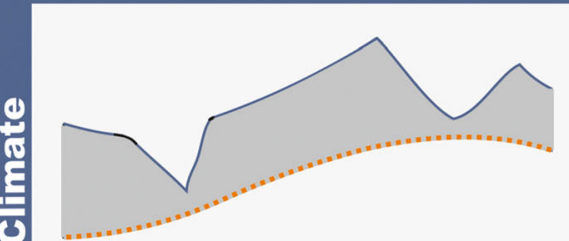

Timing: Spring drought + early summer drought Severity: Low-intermediate

\section{Storage driven}

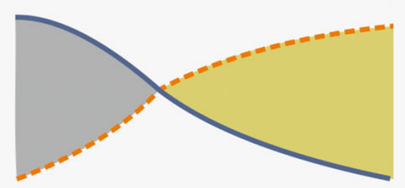

Timing: Summer drought

Severity:lintermediate - high

\section{Residual moisture}

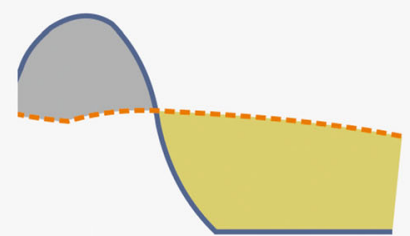

Timing: After rainy season

Severity: High

\section{Drought escape}
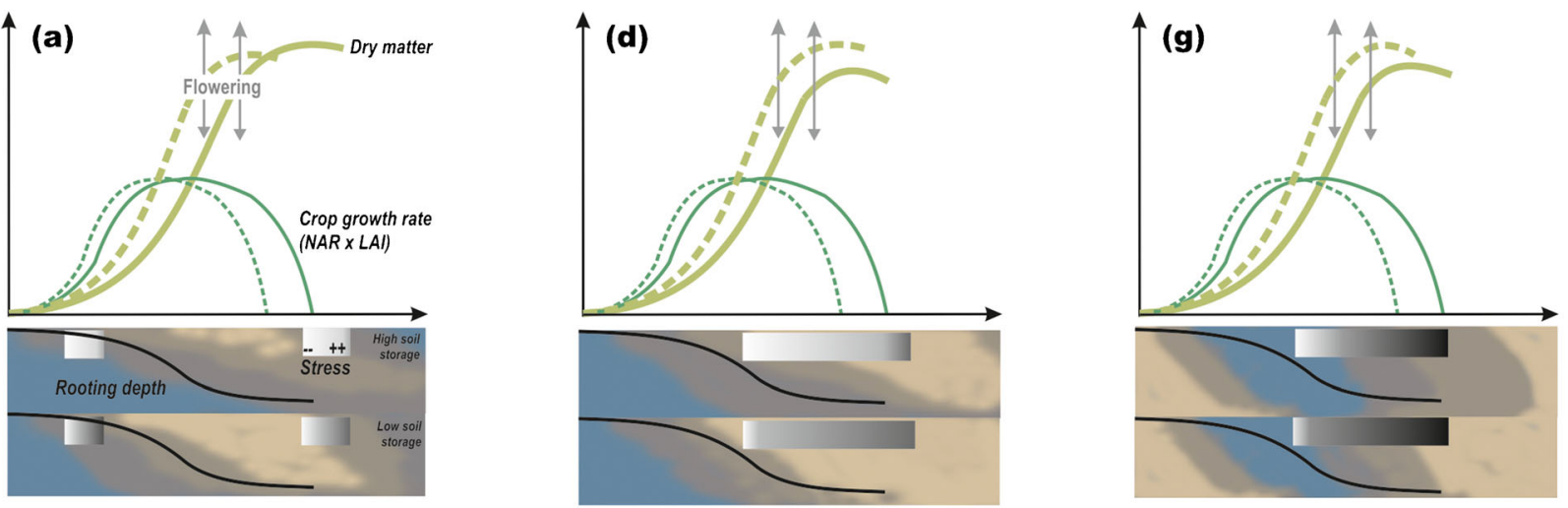

\section{Water saving}
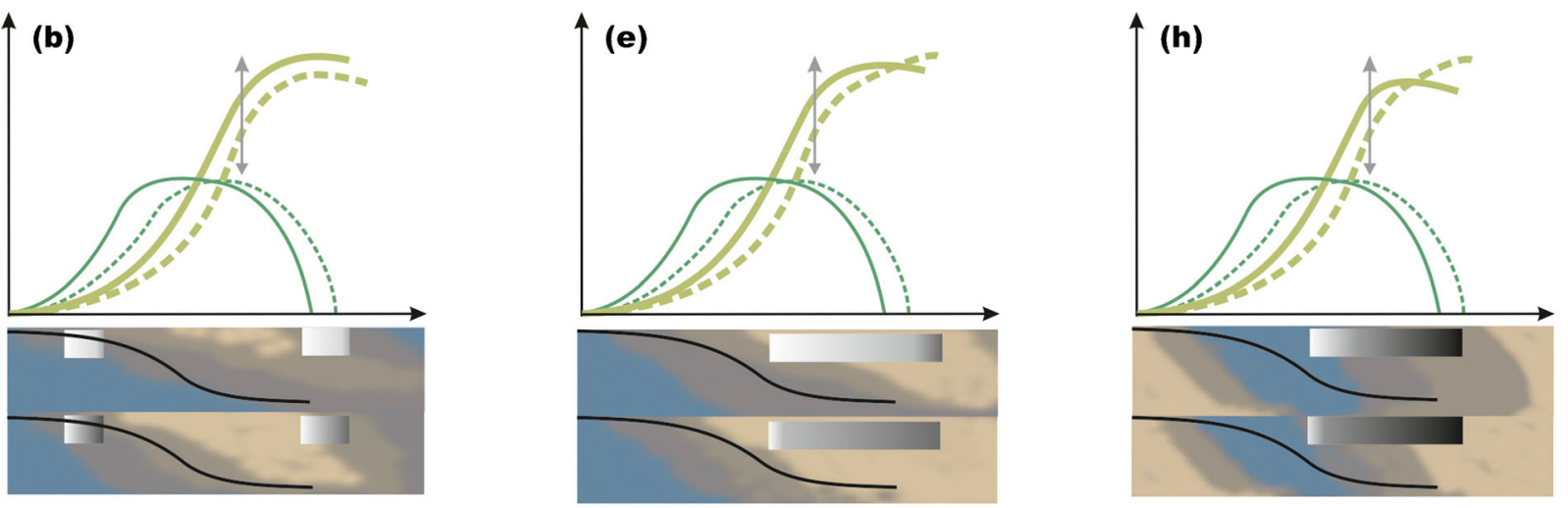

\section{Water spending}
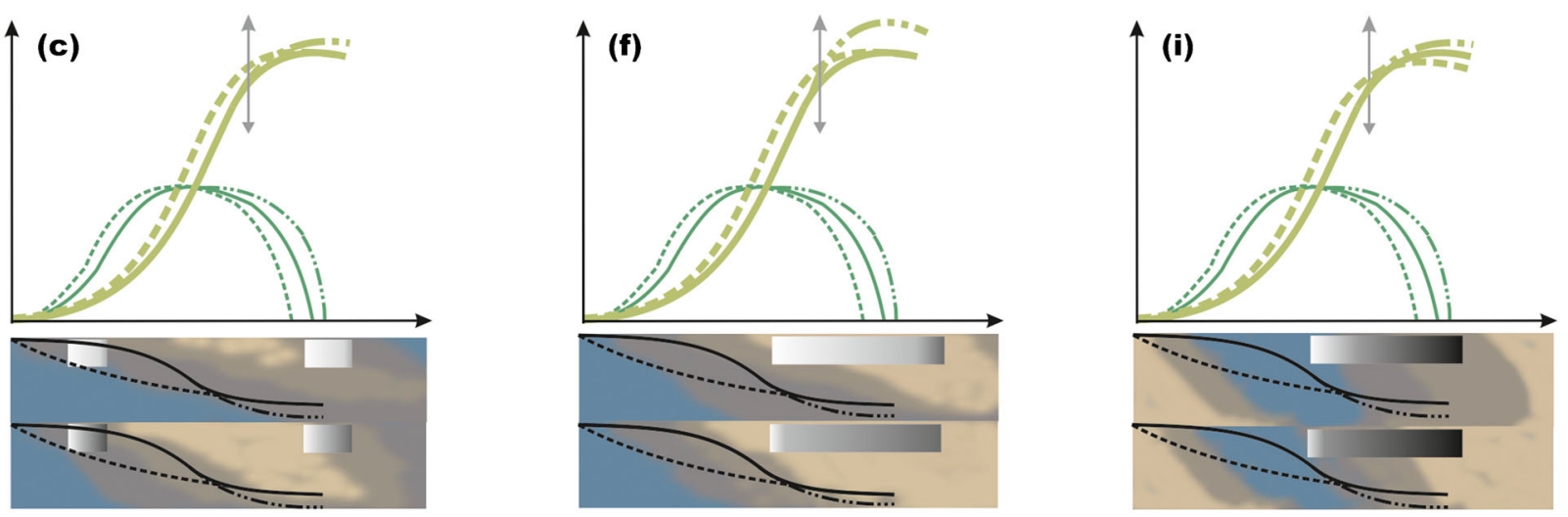
High early vigour, a trait related to drought escape (Fig. 7a), implies a high crop growth rate. The advantage of earliness in a supply-driven climate with summer peak rainfall, however, is limited to drought prone low storage soils where intermittent periods of early summer rainfall shortage quickly result in plant stress. Generally, there is a high probability of sufficient supply during grain filling. Thus, earliness could even imply the risks of lower yield potential due to shortening of assimilation period. Still, climate change predictions of more frequent generative drought under currently supply-driven conditions suggest that also for these environments cultivars might require a shift to earlier maturity as an adaptive strategy (e.g. Gouache et al. 2012).

A main difference between cultivars released for waterlimited vs. non-limited sites is harvest index (Hay 1995). Dwarf cultivars have an optimised stature to maintain high radiation use, improve generative sink strength and continued assimilation by high flag leaf area duration (Araus et al. 2002). Reduction of leaf layers in dwarf cultivars is an effective way of water saving (Fig. 7b), compatible with high yield as light interception is not compromised (Miralles and Slafer 1997). With optimised leaf area, sensitive stomata response to water shortage could provide additional water saving due to higher intrinsic water-use efficiency (Condon et al. 2002). However, in temperate summer-rainfall climates, the role of water saving during vegetative growth is minor because of less frequent generative stress. Although coarse textured or shallow soils have higher probability of terminal drought, for these sites, water saving is constrained by their limited water storage capacity. For cereals, early drought can seriously impair yield because yield components (number of tillers/spikes, spiklets per spike) are preformed during vegetative development stages (e.g. Aspinall et al. 1964; Rawson and Macpherson 2000). Conservative water use combined with early stress might imply lower uptake during these stages, resulting in excessive reduction of yield components, low generative sink strength and thereby lower final yield. Reviewing carbon isotope discrimination studies, Condon et al. (2002) demonstrated that water saving via tight stomata control negatively affected yield in case of supply-driven environments due to higher amount of water remaining in the soil after maturity and higher evaporation losses because of lower crop growth rate.

Water spending (Fig. 7c) implies effective use of water mediated by adapted root systems, reduced non-stomata and evaporation losses and osmotic adjustment (Blum 2009). Optimisation of root water uptake can be achieved by (i) fast root depth penetration, (ii) high maximum rooting depth and (iii) increased rooting density. Rooting strategies of plants range from explorative patterns with a high rooted soil volume, e.g. via high maximum rooting depth to exploitative patterns with an intense extraction, e.g. via high fine root density (Fitter 1987; Bodner et al. 2013). Increasing importance of subsoil moisture for crop performance implies an advantage of strongly explorative root systems (Kirkegaard et al. 2007; Wasson et al. 2012). Particularly spring sown cereals may profit from quick root depth penetration to avoid early drought, making better use of post-winter water resources in deeper soil layers (Palta et al. 2011). Sustained growth during periods of early season water deficit furthermore enhances quick canopy coverage, thereby reducing soil evaporation and saving stored soil water for crop transpiration. The importance of subsoil water use via deep rooting to sustain generative growth is comparatively small in case of supply-driven summer rainfall climates. It depends on the proportion of available water in upper layers, supplied by inseason rainfall, to water from winter rainfall having percolated to lower soil layers. Lower infiltration depth of the in-season rainfall in high storage soils requires strong exploitative capacity of root systems to optimise water use and reduce evaporation (Guswa 2010). Resuming, in supply-driven ecosystems generative stress mainly occurs in low storage soils. Flowering time and plant stature, a drought escape and water-saving mechanism, respectively, have already been largely optimised by breeding. Additional avoidance of intermittent early season drought could be expected from quick root penetration as well as sustained water exploitation capacity from drying soil by dense rooting systems. The projected changes in rainfall distribution with more frequent terminal stress, however, will also increase the importance of subsoil water exploration. Under current climate conditions, crops with long vegetation period profit from better buffering of short-term water shortage during summer via additional subsoil water uptake. This capacity of species/cultivars is most effective in high storage soils and after sufficient winter rain to refill deep layers. It is particularly important for crops with deep root systems such as sugar beet (Ober et al. 2005), while maize has been adapted to summer drought by less susceptible flowering biology with reduced anthesis-to-silking interval (Campos et al. 2004). Still, also for maize and sunflower, improved root water and nitrogen uptake capacity has been related to improved yields under stress via the phenomenon of delayed leave senescence or stay green (Trachsel et al. 2009; Hammer et al. 2009; Lisanti et al. 2013).

Crop growth and yield formation increasingly depend on subsoil moisture under summer-dry storage-driven and tropical/subtropical residual moisture ecohydrologies. Beside the unfavourable distribution of rainfall supply, high potential water losses (cf. Section 3.2) and a higher evaporative demand compared to temperate climates are the reasons for more difficult crop water management. Typical rainfed crops in summer dry storage-driven hydrologies are cereals such as Triticum aestivum L., Triticum turgidum ssp. durum L., Hordeum vulgare L., Sorghum bicolor Moench, legumes such as Vicia faba L., Cicer arietinum L., Lens culinaris Medik., as well as other species such as Helianthus annuus L. and 
Gossypium hirsutum L. In tropical/subtropical residual moisture climates common rainfed crops are S. bicolor Moench., Pennisetum glaucum (L.) R. Br., Zea mays L., G. hirsutum L., Oryza sativa L., Saccharum officinarum L., Sesamum indicum L., Vigna unguiculata (L.) Walp, and Arachis hypogaea $\mathrm{L}$.

In storage-driven winter rain climates, the rainfed cropping season is limited by summer drought. Drought escape (Fig. 7d) adapts crop phenology to the seasonal water availability to avoid severe terminal stress during grain filling (e.g. Thomson et al. 1997; Francia et al. 2011). High early vigour furthermore provides quick canopy coverage, reducing evaporation as a principal loss component in storage-driven ecosystems (Turner 2004; Slafer et al. 2005; cf. Fig. 4). Water saving (Fig. 7e) strives to an optimisation of water use over the whole vegetation period, conserving water during early stages, with better supply from stored winter rainfall and incoming spring precipitation, for the dryer and most sensitive later growth stages (flowering, grain filling). At the same time, the extent of conservative water use should not risk to leave unexploited water in the subsoil after harvest. Water saving has been approached via root adaptation, e.g. reducing seminal root axial conductance (Richards and Passioura 1989) as well as leaf adaptation, e.g. via high intrinsic water-use efficiency (Condon et al. 2002). While some authors reported improved yields from conservative water use (e.g. Mori and Inagaki 2012), disadvantages are increased evaporation losses (Condon et al. 2002) as well as reduced assimilation potential in years with better water supply (Blum 2009). Lower productivity of water-saving genotypes is a result of reduced stomata conductance, while it could be avoided if high intrinsic water-use efficiency is achieved by enhanced photosynthetic capacity (Udayakumar et al. 1998; Gilbert et al. 2011). Successful water saving strongly depends on water storage capacity and is therefore less effective in low storage soils compared to the phenological adaptation via drought escape.

Water spending refers to an effective root water uptake optimising the use of available resources for crop supply. Effective water spending (Fig. 7f) of available soil moisture is the key to exploit the site-specific growth potential in environments depending on stored soil water. Kirkegaard et al. (2007) demonstrated the high efficiency of subsoil water use for yield production in wheat. Effective uptake depends mainly on root traits. Several studies demonstrated that rooting depth is the most important variable for optimum subsoil water use to avoid drought (Hamblin and Tennant 1987; Hund et al. 2009a; Wasson et al. 2012). Waines and Edhaie (2007) showed that modern wheat cultivars have a small root system compared to landraces that might be insufficient for optimum water uptake. In case of lower subsoil water availability, as a result of lower storage capacity or reduced infiltration depth of winter rain, rooting depth is less effective while rooting density can improve a quick exploitation of water resources that otherwise get lost by evaporation or drainage.

Tropical and subtropical residual moisture environments are most demanding for rainfed crop production due to unfavourable rainfall distribution, high evaporative demand and high potential of unproductive water losses. Compared to Mediterranean environments with gradual development of drought towards summer, here, the dry season follows closely the rainy period. Furthermore, intermittent drought during the rainy season can build up quickly due to the high evaporative demand. Under these conditions, most crops experience some degree of terminal stress during grain filling. Drought escape (Fig. $7 \mathrm{~g}$ ) can limit the intensity of stress due to higher early vigour reducing evaporation losses and better matching of flowering and early grain filling with times of sufficient water availability (Van Oosterom et al. 1996; Serraj et al. 2003; Clavel et al. 2005).

Taking into account the quick and intense onset of postrainy season stress, water saving (Fig. 7h) by a balanced vegetative use is imperative to save sufficient soil moisture for grain filling (Kholová et al. 2010; Zaman-Allah et al. 2011). Among crops with $\mathrm{C}_{4}$ photosynthesis having a generally high water-use efficiency (Brown 1999), pearl millet is most drought resistant, which was related to a constitutively low water use and highest water-use efficiency under severe drought (Singh and Singh 1995; Zegada-Lizarazu and Iijima 2005). Here, also the whole crop rotation has to be considered. When including a second dry season crop, termed Rabi crop in the Indian subcontinent from the Arabic word for spring, following the main rainy season crops, termed Kharif crops from the Arabic word for autumn, it depends almost exclusively on stored moisture. In this case, water allocation has to be planned for the whole rotation with maximum water storage during the rainy season and water saving of the rain season crop to avoid detrimental profile depletion levels for the subsequent crop.

High capacity of water spending (Fig. 7i) is of obvious importance when growth during part of the crop cycle exclusively depends on stored soil water. For intermittent drought during the rainy season, deep rooting allows sustained transpiration by better subsoil water use. Comparative studies of maize, sorghum and millet (Muchow 1989; Singh and Singh 1995; Farré and Faci 2006) demonstrated that sorghum with highest subsoil water uptake out-yielded maize and millet at intermediate drought severity, while millet was superior under severe drought due to its efficient water saving. Concerning root traits, we suggest that sustaining the high transpiration demand under severe drought and insufficient subsoil water availability in tropical and subtropical conditions, traits related to high exploitation capacity such as rooting density, fine rooting and mycorrhization are of increasing importance (Kashiwagi et al. 2006). Vadez et al. (2007) reported that extensive studies on root distribution and transpiration under 
drought at ICRISAT, India, did not show a clear relation between root morphology and functioning, i.e. water uptake. In a modelling study, Preti et al. (2010) found superficial root allocation to be optimum in clay-textured soils and under large evaporation to precipitation ratio. This scenario would correspond for example to heavy tropical Vertisols where potentially high residual water content in dry soil requires high exploitation efficiency. In addition, plants growing on low storage soils in severely dry, pulse rainfall environments follow an exploitative rooting strategy: Here, dense and shallow root systems with large lateral extension provide optimum rainfall capture (Schwinning and Ehleringer 2001). Besides rooting density, also osmotic adjustment is crucial to sustain water extraction from dry soil (Sharp and Davies 1985; Blum 2005; Aroca and Ruiz-Lozano 2012). Finally, we notice that the role of dehydration tolerance becomes more important for severe drought environments. Traits such as cell membrane stability (e.g. Blum and Ebercon 1981) and remobilisation of stem carbohydrates towards grain sinks (e.g. Muchow 1989; Blum 1998) are essential for successful crop growth.

Table 1 resumes the efficiency of different drought resistance strategies according to the hydrological regimes. We recall the distinction between drought and a climatic dry season with drought being an unusual deviation from climatic normality. Frequently species/cultivars are adapted to a given dry climate, and therefore, certain improvement strategies have been largely exploited. Still, crop adaptation to the high variability of stress intensity between years and to intermittent drought is challenging. Inter-annual variability of stress requires strategies to reconcile growth potential and stress resistance. Intermittent drought is most risky for hot tropical environments where stress may build up quickly even during the rainy season in case of abnormally dry years leading to complete crop failure (Serraj et al. 2003).

Table 1 Efficiency of drought resistance strategies for crop growth under different hydrological regimes

\begin{tabular}{llll}
\hline & Supply driven $^{\mathrm{a}}$ & Storage driven & Residual moisture \\
\hline Drought escape $^{\mathrm{b}}$ & + & ++ & ++ \\
Water saving & - & + & +++ \\
Water spending & +++ & ++ & + \\
\hline
\end{tabular}

Efficiency decreases from high (+++) to no effect (-)

${ }^{\text {a }}$ Suppy driven refers to environments with in season rainfall and intermittent dry periods; storage driven refers to winter rainfall climates with increasing stress towards grain filling; residual moisture refers to the continuously dry post-monsoon season of tropical/subtropical environments (details cf. Fig. 4 and related text)

${ }^{b}$ Drought escape refers to crops with adapted phenology, e.g. early maturity; water saving refers to tight stomata control of water consumption; water spending refers to efficient root water uptake (details cf. Fig. 7 and related text)
Under supply-driven conditions of continental climates, crop growth potential is generally high. Both early vegetative and late generative droughts might occur as yield limiting phenomena. In this climate, drought avoidance by sustained uptake, i.e. water spending, is feasible and most compatible with the high yield potential. Increasing root uptake capacity allows buffering efficiently short duration and moderate water stress. In summer-rainfall climates with low terminal stress frequency, the advantage from water saving and drought escape is small. Furthermore, cultivars have been adapted in earliness, i.e. drought escape, and harvest index, i.e. water saving during vegetative growth. Further change of these traits without negative trade-off for potential yield is restricted. Root traits on the contrary are hardly exploited and compatible with high assimilation potential. Under storage-driven environments with gradually increasing stress towards maturity, drought escape is effective to adapt phenology to the variable local conditions of water availability and thereby limit stress at flowering and grain filling. Water saving can also contribute to avoid terminal drought. However, the annual variability in rainfall amount implies that winter rainfall climates experience both years with low and high stress intensity. Here, conservative water use may limit yield potential during better years. Drought avoidance by increased subsoil water exploration, e.g. via high rooting depth, should be preferred in case of high storage soils. Crops growing on residual moisture in the post-monsoon dry season of tropical and subtropical environments experience continuous stress. Therefore, water saving is essential to ensure sufficient water for the whole growing cycle, particularly for grain filling. Furthermore, dehydration tolerance to overcome severe drought events is of increasing importance, mainly for crops grown during the post-rainy season. Water spending via efficient uptake- with soil conditions determining if explorative or exploitative root traits are preferred-is still important to overcome intermittent drought previous to the prolonged water shortage of the dry season.

\subsection{Subsystem interactions and feedbacks}

After having described the main properties and processes determining water dynamics in the climate, soil and plant subsystems, we will now discuss some relevant interactions between subsystems. Ehrenfeld et al. (2005) differentiated between interaction and feedback, where the first refers to a cause-effect process, while the latter requires that the result of a process changes the cause itself. However, he noticed that most research only demonstrate cause-effect relations, which might be part of feedback processes without proving them, mainly due to restricted time of the respective studies.

We will focus here on interactions that can be influenced by management. In accordance with Sposito (2013), we consider that managing complex plant-soil interaction is an unexploited field to allow sustainable intensification of crop production, 
taking into account the constraints to other ways for increasing food production such as land conversion and blue water use.

A first type of subsystem interactions with relevance to management are between climate and soil. Beside texture, structure is fundamental for the hydraulic behaviour of soils. Soil structure is a highly dynamic property varying over space and time (Schwen et al. 2011; Bodner et al. 2013). An important climate-soil interaction can be found between rainfall intensity and infiltrability. This interaction determines if water infiltrates into the soil or is lost by surface runoff. Infiltrability can be impaired by high rainfall intensity via aggregate disruption and surface sealing (e.g. Lado et al. 2004). This climate-soil interaction points to the importance of managing soil surface properties to reduce runoff losses (Pikul and Zuzel 1994). Evaporation underlies a similar climate-soil interaction with important management implications. Postharvest stubble tillage is intended to create a coarse surface soil structure disrupting pore continuity and reducing unsaturated hydraulic conductivity of medium to fine textured soils. Thereby, rainfall storage between two crops should be increased by lowering water losses from unplanted soil. However, high rainfall frequency and wetting-drying result in soil settlement and reestablishment of pore continuity via capillarity driven aggregate coalescence in these types of soils (Leij et al. 2002). Thus, evaporation itself conditions evaporability because of a wetting-drying induced change in soil surface structure (Or et al. 2013).

A second type of important subsystem interactions occurs between plant and soil. Here, feedback processes in a strict sense can be found. Plant-soil interactions with relevance to crop production under water limiting conditions are (i) mulch/ canopy coverage-surface soil interactions, (ii) plant residuesoil organic matter interactions and (iii) root-soil interactions. Interactions between plant and soil surface structure are of key importance in relation to runoff and evaporation control. Plant-soil surface structure interactions are proper feedback process: Plant canopies and/or residues from previous crops reduce runoff and evaporation and thereby enhance further plant growth due to better water availability. Plant effects on surface soil structure are related to the protective canopy effect against aggregate slaking (Zuazo and Pleguezuelo 2008), root/mycorrhiza enmeshment of (macro)aggregates (Gyssels et al. 2005; Kohler-Milleret et al. 2013), more active soil macrofauna (Facelli and Pickett 1991; Lavelle et al. 2006), enhanced microbial activity in shaded soil due to less extreme temperatures and reduced ultraviolet radiation (Hatfield and Pruegar 1996; Zogg et al. 1997; Ballaré et al. 2011) and lower coalescence due to less drying of soil under canopy/mulch coverage (Mulumba and Lal 2008).

Many agricultural management measures target the interaction between plant residues and soil organic matter. The importance of plant residue turnover for soil aggregation at different scales has been extensively studied (e.g. Tisdall and
Oades 1982; Six et al. 2004; Bronick and Lal 2005). The concomitant change in plant water availability has been reviewed for different soil textures by Rawls et al. (2003). Beside post-harvest crop residues, there is a continuous carbon input during plant growth via rhizodeposition (Nguyen 2003). This continuous input is an essential feedback component in the plant-soil system: Besides enhancing soil aggregation (Traoré et al. 2000), it lowers soil mechanical resistance for root penetration (Bengough et al. 2011) and improves rhizosphere water storage (Carminati and Vetterlein 2012).

Plant scientists and modellers studied root-soil interactions, as a third type of plant-soil structure interactions, mainly looking on the dynamics of root growth and architecture driven by a static soil environment (e.g. Hodge et al. 2009; Leitner et al. 2010). However, it is evident that roots themselves micro-engineer their environment optimising conditions for growth and uptake processes (Young and Crawford 2004; Gregory 2006). "Biodrilling" has been suggested as targeted soil conditioning via plant roots to improve crop growth (Yunusa and Newton 2003; Williams and Weil 2004). Still, there continues to be a challenging gap between qualitative evidence, quantification and targeted management (Gregory et al. 2013).

Finally, there is an important domain of manageable subsystem interactions between plant and (micro)climate. The microclimate within a crop stand essentially determines the amount of vapour transfer via the leaf boundary layer resistance and the overall water potential gradient driving the flux through the SPAC (Jones 1992; Monteith 1995). Depending on canopy architecture, several meteorological variables such as radiation, $\mathrm{CO}_{2}$ concentration, temperature, humidity and wind speed differ within a crop stand from the surrounding atmosphere. This interaction influences photosynthesis as well as transpiration via modified radiation and $\mathrm{CO}_{2}$ supply and water demand (e.g. Baldocchi et al. 1985). Jones (2009) demonstrated that a large boundary layer resistance, e.g. due to low wind speed or a dense canopy, results in an incomplete coupling between plant and atmosphere. As assimilation is less dependent on the atmospheric coupling compared to transpiration the instantaneous water-use efficiency within the crop canopy increases. Another plant-microclimate feedback is dew formation, which constitutes a significant water input in arid ecosystems (Agam and Berliner 2006; Konrad et al. 2014). Both feedback mechanisms increase water-use efficiency of close crop canopies and are relevant processes in managing crop water supply.

\section{Efficiency of management measures in different hydrological regimes}

Management of water-limited cropping systems requires a precise knowledge of those subsystem properties and 
processes that are responsible for a sub-optimum water use. The fundamental dependence of water dynamics on hydrological site conditions implies that agricultural interventions have to be adapted to the specificity of the drought environment. After defining a general framework to analyse the efficiency of agricultural water use, we will review the role of different management measures to increase productivity in different drought environments, which have been defined above in relation to soil and plant subsystem properties and processes (cf. Figs. 4 and 7).

\subsection{A framework for efficient agricultural water use}

Several authors have suggested conceptual models to analyse water-use efficiency in agriculture (e.g. Passioura 1977; Gregory 2004; Debaeke and Aboudrare 2004; Hsiao et al. 2007; Moore et al. 2011). Passioura (1977) presented the following classical field scale approach to analyse yield formation in water limiting agro-ecosystems:

Yield $=\mathrm{WU}^{*} \mathrm{WUE} * \mathrm{HI}$

where WU is water uptake (equal transpiration), WUE is water-use efficiency and $\mathrm{HI}$ is harvest index. However, using the common definition of WUE, i.e. WUE $=B / T$ with $B$ being biomass and $T$ transpiration, Blum (2009) pointed to the problem that WU and WUE are not mutually independent terms. Thereby, Eq. 2 reduces to the basic relation of

Yield $=B^{*} \mathrm{HI}$

Passioura (2006b) specified that strategies for crop improvement in water-limited ecosystems have to provide high capacity of water uptake, efficient gas exchange, i.e. instantaneous WUE, and high harvest index. Here, water uptake and WUE refer to different scales, i.e. whole plant vs. stomata, and can be considered as independent.

Blum (2009) suggested using the equation of de Wit (1958) as cornerstone for analysing the biomass-water use relation:

$B=\frac{m T}{E T_{0}}$

where $B$ again is biomass, $m$ is a crop constant and $T$ transpiration. $E T_{0}$ is used for standardisation when comparing sites or seasons with different evaporative demand. The crop constant $m$ is equal to the slope of a linear relation between biomass and transpiration, i.e. transpiration efficiency. Steduto et al. (2007) among others demonstrated that transpiration efficiency is a rather conservative parameter owing to the low variability in basic biochemical efficiency of photosynthesis. Essential differences exist between $\mathrm{C}_{3}$ and $\mathrm{C}_{4}$ crops and during the reproductive stage due to the different metabolic costs of storage organs, with carbohydrates $<$ protein $<$ oil. Equation 4 therefore suggests that the two main sources of variable efficiency in the biomass-water use relation are the amount of water transpired $(T)$ and the meteorological conditions, i.e. evaporative demand $\left(E T_{0}\right)$ during the growing season.

The relations given so far target the crop in a strict sense, being intended to guide breeding efforts. Gregory (2004) extended the focus to the overall cropping system. He defined water-use efficiency as

$\mathrm{WUE}=\frac{B}{T}\left(\frac{1}{\frac{E+R+D}{T}}\right)$

where $B / T$ refers to the transpiration efficiency of the crop, while the second term focuses on soil management efficiency based on a field water balance. The ratio $(0-1)$ between productive plant water use $(T)$ and water loss components, i.e. $E$ for evaporation, $R$ for runoff, and $D$ for deep drainage, thereby relates the physiological efficiency of the crop to the field scale. Combining the field scale Eq. 5 with the two crop scale Eqs. 3 and 4, we obtain the following relation for yield production in a water-limited cropping system.

Yield $=\mathrm{HI} \cdot \sum_{i} \frac{m_{i} T_{i}}{E T_{0 i}} \cdot\left(\frac{1}{\frac{E_{i}+R_{i}+D_{i}}{T_{i}}}\right)$

This equation satisfies the crop ecological requirement to consider plant physiology $(m, T, \mathrm{HI})$, soil $(E, R, D)$ and climate $\left(E T_{0}\right)$ within a single analytical framework that targets crop yield formation. HI is dimensionless, $m$ is in grams per square metre and $E T_{0}, T, E, R$ and $D$ are all in millimetre. For proper analysis, Eq. 6 should be applied separately for the vegetative and generative stages mainly because of the differentiation in $m$ between these two stages. The index $i(i=1$ to $n$ ) refers to the number of stages to be distinguished, e.g. in case of separate analysis of vegetative and generative stage, $i$ is 2 and the transpiration dependent biomass of the respective stages is summed.

\subsection{Management measures}

Figure 8 gives an overview of soil and plant management measures to improve productivity of water-limited cropping systems and highlights which subsystem processes or 
Fig. 8 Short- and long-term management measures and their effects on water-use efficiency and drought stress resistance. Short-term measures adapt the cropping system to site conditions, while long-term measure strive to improve environmental constraints of a site. Arrows indicate concomitant and/or successive effects of a given practice on other measures

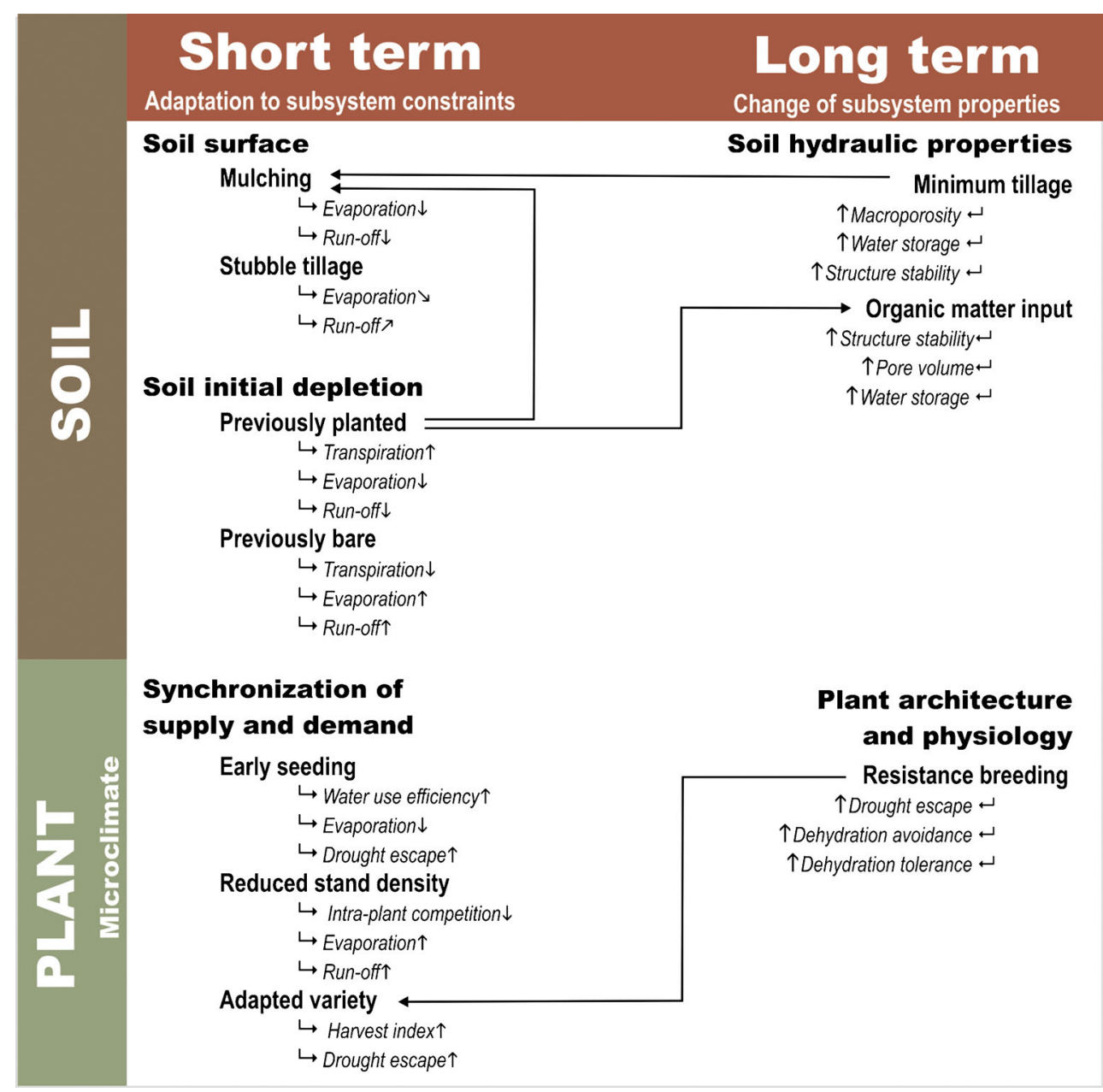

properties are targeted. It is useful to differentiate between measures acting at a short time scale and those acting at a longer time scale. Short-term measures strive to change a yield limiting subsystem process, leading to an improved agricultural practice with immediate impact for the given cropping season. Long-term measures on the contrary imply deeper and more complex changes to overcome constraints within subsystem properties. Time scale, cost and effective yield improvement commonly decide on the likelihood of adaptation of any measure to farmer's practices. It should be recorded that higher yield is the main agricultural target, while other stakeholders might also judge the efficiency of management change via a reduced agricultural water consumption without changes in yield level.

\subsection{Soil-related measures}

The soil subsystem is mainly influenced by the tillage system, which has both short- and long-term impacts. A second important management impact on soil processes and properties is crop rotation. Short term effects of soil management target the soil surface and the initial soil water depletion at the onset of main cropping season. Long-term effects comprise a number of changes in soil hydraulic properties.

\subsection{Short-term measures}

\subsubsection{Mulching}

Tillage systems modify soil surface properties by different degree of soil coverage. Soil coverage can be achieved by crop residues (mulching), a living canopy cover (cover cropping, relay intercropping) or non-crop mulch material (plastic foil, geo-textile). Soil coverage is intended to reduce runoff and evaporation from bare soil surfaces. The respective importance of these two loss terms in different climates was discussed in Section 3.2 and resumed in Fig. 4. For supplydriven conditions, Kálmar et al. (2013) studied post-harvest mulching on a chernozem soil in central Hungary with annual rainfall of $580 \mathrm{~mm}$ and mean temperature of $10{ }^{\circ} \mathrm{C}$. They measured $8-11 \%$ higher soil water content in $0-65 \mathrm{~cm}$ soil depth for undisturbed mulch covered soil with 55-65\% coverage compared to a conventionally tilled soil without mulch cover. This indicated reduced evaporation losses during 
summer months. A similar result was reported by Sinkevičienè et al. (2009), while Raza et al. (2013) did not find significant mulch related differences in near surface soil moisture. The data of Kálmar et al. (2013) on different degrees of coverage clearly indicate that evaporation reduction requires a minimum coverage of $>50 \%$. Compared to other reports, this is still a comparatively low percentage (e.g. Unger et al. 1991; Mitchell et al. 2012).

Also under Mediterranean conditions, surface coverage is an important water conservation practice. Mrabet et al. (2003) reported $10 \%$ higher water storage over summer when soil was covered by a mulch layer compared to no coverage. Lampurlanés and Cantero-Martínez (2006) demonstrated that higher water content under no-tillage compared to conventional tillage in a Mediterranean climate was attributed exclusively to the higher residue cover. Furthermore, Verhulst et al. (2011), comparing no-tillage and conventional tillage with and without residues in an experiment in Mexican highlands, confirmed that higher soil water content was generally found under residue covered treatments, particularly during dry periods. According to Bennie et al. (2001), evaporation reduction by residues is effective during the first 10 days after surface wetting and requires a minimum of $80 \%$ shading. The high effect during the energy limited first stage of evaporation decreases during the flux limited second stage and diffusion limited third stages of evaporation (Steiner 1994). Long-term moisture conservation during prolonged dry periods is less feasible (Yunusa et al. 1994).

In a tropical residual moisture regime, Zaongo et al. (1997) reported a $28 \%$ decrease in evaporation by mulch coverage. A similar value was measured by Eberbach et al. (2011). Ramakrishna et al. (2006) found up to $22 \%$ higher soil water content in a mulched soil profile. A comprehensive modelling study of Jalota and Arora (2002) confirmed that mulching was highly effective to reduce evaporation, which was the dominant water loss component in the simulated dry tropical environment.

Concerning runoff losses, the protective effect of surface residues is largely documented. Runoff decreases exponentially with increasing surface cover. According to the USDA, minimum tillage is defined as having a least $30 \%$ ground cover and no-tillage $50 \%$ cover, respectively (Rust and Williams s.a.). Following the relation given by Zuazo and Pleguezuelo (2008), expected average runoff reduction would be 75 and $90 \%$, respectively. Klik and Eitzinger (2010) estimated a $36 \%$ reduction in runoff losses by no-tillage compared to conventional tillage for the erosion sensitive semiarid hilly region of Eastern Austria. At a Mediterranean site in South East Spain, Gómez et al. (2004) reported a 66 \% reduction of runoff by grass cover compared to a bare soil surface. Cogle et al. (2002) measured $64 \%$ reduction in runoff by rice straw amendment compared to an uncovered soil during a 5year experiment in the semi-arid tropics in India. Comparison between runoff reports, however, is difficult due to large variability in experimental conditions.
The overall hydrological role of mulching is resumed in Box 1. In spite of a general positive hydrological impact of mulching in all water-limited environments, implementation can conflict with other residue uses (particularly animal feeding in the context of small-holder farmers; Erenstein 2002) as well as phytosanitary considerations (e.g. Sturz et al. 1997).

\begin{abstract}
Box 1: Mulching and water management
Mulching is highly effective to prevent evaporation and runoff, being the dominant loss components in most dryland ecosystems. Concerning evaporation, surface covers provide an effective buffer for dry spells during rainy periods with high evaporative demand (e.g. temperate climate summer, tropical rainy season). The effect is highest after surface wetting and decreases with time due to drying of the soil surface. A main challenge is the relatively high residue cover required for an effective control. Surface cover effects on runoff are high even at lower coverage. The reduction in runoff is mainly a function of site specific vulnerability, which is particularly high on steep slopes during concentrated rainy seasons in semi-arid tropics and for plantations (e.g. olives, citrus, vineyards) with large area of bare soil surface as frequently found in Mediterranean cropping systems.
\end{abstract}

\subsubsection{Stubble tillage}

A common measure to reduce post-harvest evaporation losses is stubble tillage. It is a measure applied during the fallow period between consecutive crops, while surface cover by mulch can potentially protect the soil surface during the whole year. As reported above, evaporation during prolonged dry periods is low and also other losses (runoff, drainage) are negligible during dry seasons in storage-driven and residual moisture ecosystems. Thus, stubble tillage for water conservation is mainly effective in supply-driven summer-rainfall agro-ecosystems. Several recent studies, however, questioned the water-saving potential of stubble tillage (Pekrun et al. 2011; Kálmar et al. 2013). Also early studies from semi-arid summer rainfall sites in the US Great Plains, resumed by Unger et al. (1991), reported lower water storage during the fallow period, higher evaporation as well as increased runoff from stubble tilled compared to residue covered soils. Therefore, evidence is growing that stubble tillage as a traditional management measure before summer fallow in semi-arid supply-driven ecosystems is ineffective for soil water and rainfall conservation.

\subsubsection{Initial depletion}

Bare soil fallowing is a traditional measure for soil recovery. In water-limited ecosystems, it is mainly intended to replenish soil water storage before the subsequent main crop. Depending on the extent of drought and rainfall distribution, fallowing might extend from short duration of unplanted soil between two consecutive crops to a whole non-cropped vegetation period.

In supply-driven cropping systems, there was traditionally a fallow period between harvest in early summer and the 
subsequent crop seeded in late autumn or after winter. Although there were early advocates of permanent plant cover (e.g. Sekera 1943), only recently cover crops have been promoted as an alternative to bare soil fallowing. They avoid nutrient losses and soil erosion, provide additional organic input to the soil and improve its physical, chemical and biological quality (MacRae and Mehuys 1985; Meyer et al. 1999; Schutter and Dick 2002; Vidal and López 2005; Liu et al. 2005). Introduction of an additional crop, however, was considered to reduce water storage compared to an otherwise bare soil, resulting in higher depletion at planting of the subsequent main crop (Mitchell et al. 1999; Nielsen and Vigil 2005; Islam et al. 2006). On the contrary, Bodner et al. (2007) reported only low differences in evapotranspiration between a cover cropped and a bare soil under semi-arid, supply-driven conditions in East Austria. In a related simulation study, Bodner et al. (2010) showed that there were hardly any differences in spring profile water storage and no significant relation between cover crop water consumption and yield of a subsequent maize crop. These different findings are mainly related to the duration and climatic conditions during cover crop growth. Those studies reporting significant soil water depletion were conducted in locations with higher temperature during cover crop growth (Central Great Plains; Nielsen and Vigil 2005) and/or predominant winter rainfalls (California; Mitchell et al. 1999; Islam et al. 2006). On the contrary, in the semi-arid continental climates of Central and Eastern Europe, the main growing period of cover crops is autumn until crops are terminated by frost before winter. Due to the low evaporative demand during their growing period, they show high water-use efficiency and low water consumption (Bodner et al. 2007). Thereafter, winter rainfall is generally sufficient to refill water storage.

There are also reports of cover cropping during the rainy season in dry Mediterranean and tropical climates where the yield risk of soil water depletion is higher due to storage dependence of the subsequent crop. The comprehensive study of Islam et al. (2006) showed a substantial reduction in soil water recharge by winter rainfall with cover crops. In addition, Ward et al. (2012) found reduced soil water storage induced by a cover crop. However, both studies indicated that early killing of cover crops reduced their water consumption while maintaining hydrological advantages like reduced evaporation, higher rainfall infiltration and lower runoff. In semiarid tropics where the rainy season is mostly used for cash crop growth, cover cropping is hardly feasible. In more subhumid conditions, however, legume cover crops, often established within relay intercropping system, could offer possibilities to alleviate $\mathrm{N}$-fertilizer constraints and improve soil fertility. Bayala et al. (2012) studied conservation agriculture in semi-arid tropics and showed that cover crops were found at sites with rainfall higher than $600 \mathrm{~mm}$, while positive yield effects were reported when rainfall exceeded $800 \mathrm{~mm}$.
In dry Mediterranean regions, traditional farming systems were often based on biennial crop rotations including a fallow year between main crops (Ryan 2011). Due to increasing land pressure, fallows have decreased and extensive studies have been conducted for improved rotations including feed legumes. Comparing barley following fallow or legumes such as vetch and lathyrus as well as barley mono-cropping, Jones and Sigh (2000) showed highest overall growth potential in the barley-legume systems. Pala et al. (2007) compared several improved biennial rotations with wheat as main crop in terms of yield and water-use efficiency. Highest availability of stored soil moisture after fallow resulted in best wheat yields. Still, also vetch and lentil conserved sufficient water for relatively high wheat yield and resulted in highest water-use efficiency on a system basis. Inefficient rainfall storage during fallowing, due to high evaporation losses and weed growth, has therefore led to improved crop rotations in several Mediterranean cropping regions (Farahani et al. 1998).

In semi-arid tropical and subtropical regions, the main cropping season largely coincides with the rainy season. Still. some crops, e.g. chickpea, wheat, pearl millet, mustard, are also grown in the post-rainy season relaying most exclusively on residual soil moisture (Serraj et al. 2003). Rao et al. (2011) provided evidence that cropping system intensification from a single crop following fallow to double cropping is feasible on soils with high storage capacity in semi-arid tropics by better timing of rainy- and post-rainy-season crops. Water-saving practices such as mulching in the rainy season crop improves water storage for the subsequent dry-season crop (Sandhu et al. 1992; Humphreys et al. 2005). Intensification increases water-use efficiency by better using stored soil water and substantially reducing runoff and evaporation losses during the early rainy season.

A resume of management effect on the initial soil water depletion is given in Box 2 .

Box 2: Crop rotation: water storage vs. water depletion

Traditional cropping systems in dry environments frequently include prolonged periods of uncovered soil to enhance water storage. In all hydrological situations, higher productivity and more efficient soil water use beyond traditional cropping systems is feasible. Prolonged bare soil increases unproductive water losses, which otherwise could be redistributed to transpiration in an intensified crop rotation. However, increasing overall system biomass productivity still could imply lower yield of the main cash crop. This is most evident when substituting a fallow year by a biennial rotation under dry Mediterranean conditions. On the contrary, cover crops in temperate supply-driven environments are of low risk for depleting water storage due to low evaporative demand during their autumn growing season. In tropical/subtropical residual moisture environments, the amount of water conserved in soil between rainy- and dry-season crops is limited. Still, enhanced higher water-use efficiency of rainy season crops and timely sowing can optimise the availability of stored moisture to dry season crops. 


\subsection{Long-term measures}

Long-term soil management measures focus on improvement of soil water storage capacity. Storage capacity is strongly influenced by texture and profile depth, which are natural site constraints. However, two important soil properties related to water storage are essentially influenced by plant-soil interactions in the cropping system (cf. Section 3.4), i.e. soil structure and soil organic matter. Tillage and management of organic matter are key areas of agricultural practices, which both essentially condition soil hydraulic properties.

\subsubsection{Tillage systems}

There is an extensive literature on tillage influences on soil hydraulic properties. Comprehensive reviews have been presented by Green et al. (2003), Strudley et al. (2008) and Anderson (2011). A main effect of reduced tillage systems on water flow processes is related to residue cover, which has already been discussed above. Concerning soil properties, different intensity of mechanical disturbance changes the soil pore size distribution and pore geometry.

Several long-term tillage experiments have been conducted under temperate climate conditions. Azooz et al. (1996; Canada) reported higher storage pores $<7.5 \mathrm{~mm}$ diameter in no-tillage compared to conventional tillage, while the volume of pores $>150 \mathrm{~mm}$ diameter decreased. These differences were stronger in a sandy loam compared to a silty loam soil. Kay and VandenBygaart (2002) reviewed results from tillage experiments in Canada and confirmed the general trend of decreasing macropore and increasing storage pore volume in conservation tillage systems. Tebrügge and Düring (1999; Germany) found smaller total porosity and macropore volume in a long-term no-tillage systems on a silty clay loam soil, while pores $<10 \mathrm{~mm}$ were slightly higher under no tillage. Differences in total porosity and macroporosity were highly transient and reduced significantly after winter. Lipiec et al. (2006; Poland) found a more distinct peak in a bimodal pore size distribution of a silt loam soil at $1 \mathrm{~mm}$ pore radius for notillage, while the peak at $110 \mathrm{~mm}$ was more pronounced in the conventional tillage treatment. The higher macroporosity of conventional tillage increased the steady state infiltration rates.

There seem to be no substantial differences in tillage induced pore trends in other climates. Pagliai et al. (1995) analysed pore size distribution and pore geometry under different tillage systems in a silt loam and clay soil in Italy. Treatment differences were higher in the silt loam soil compared to the clay soil with higher storage pore and reduced macropore volume in no tillage. Macropore geometry in conventional tillage showed lower pore connectivity compared to no-tillage systems where macropores were predominantly of biological origin. Bescansa et al. (2006) and Fernández-Ugalde et al. (2009) reported the same trend for a clay loam and a silt loam soil, respectively, in a semi-arid climate in Spain, leading to better crop performance in the reduced tillage systems during dry years. South America is among the leading continents in reduced tillage (Derpsch 1998). Ferreras et al. (2000) and Sasal et al. (2006) found higher volume of larger pores in a loam and silt loam soils in the Argentina pampas under conventional tillage, while fine pores $<20 \mathrm{~mm}$ were slightly higher in the no-tillage system. Sasal et al. (2006) confirmed the different pore geometry of macropores between tillage systems, underlining the important role of biopores in no tillage.

Under tropical conditions, Osunbitan et al. (2005) reported lower total porosity and macropore volume under reduced tillage in a loamy sand in southwestern Nigeria. Water retention was higher in the no-tillage system at lower pressure heads $(<$ $-500 \mathrm{hPa}$ ). In spite of lower macroporosity, no tillage had highest saturated hydraulic conductivity. This reveals the importance of continuous large biopores that might have been higher in no tillage. Also in the study of Bhattacharyya et al. (2006) in a sandy clay loam soil in India, pore volume $<7.5 \mu \mathrm{m}$ was increased in no tillage, while pores $>150 \mu \mathrm{m}$ in diameter had higher volume in the conventional tillage system. Also in their study, no tillage had significantly higher saturated hydraulic conductivity. Kumar et al. (2012) reported that long-term no tillage not only increased the proportion of micropores $(<10 \mu \mathrm{m})$ but also of large macropores $(>1000 \mu \mathrm{m})$, which decisively influence saturated hydraulic conductivity.

While similar pore size distribution trends are found in most tillage trials, for saturated hydraulic conductivity some studies reported decreasing values with reduced tillage intensity, while others reported higher saturated conductivity. This is explained by the high spatial variability of large continuous macropores. In no tillage, these pores are biologically formed structures such as root channels and earthworm casts (Wuest 2001; Palm et al. 2010; Pagenkemper et al. 2013; Bodner et al. 2014). We assume that the number of biopores is not always sufficient to counterbalance the overall lower macropore volume in notillage soils. Some studies reported the reduction of differences between tillage treatments with time after soil disturbance. Particularly for tillage experiments, it is of high importance to assess temporal dynamics of the system to capture the overall management impact (e.g. Mappa et al. 1986; Kay 1990; Tebrügge and Düring 1999; Schwen et al. 2011). The key tillage effects on soil hydraulic properties are highlighted in Box 3.

Box 3: Tillage system effects on soil hydraulic properties

There is a general trend of reduced tillage to increase water storage by higher volume of fine storage pores, while total porosity and macropore volume are reduced. This trend is similar in all hydrological regimes and for variable soil textures. Tillage effects change over time, particularly in the macropore range. Macropore-dependent hydraulic properties such as saturated hydraulic conductivity, therefore, do not show a unique trend in tillage experiments. Differences between tillage systems thus cannot be fully captured without taking into account temporal variability. 


\subsubsection{Organic matter input}

The key influence of vegetation on soil hydraulic properties is largely recognised. It is a result of the soil structure-organic matter interaction. In spite of this, targeted plant based management of soil hydrology is still at its infancy. This is mainly due to the complex and dynamic, biologically mediated processes driving the feedback between plant and soil (Angers and Caron 1998). There are two main approaches to manage soil hydraulic properties: The first is organic fertilization using, e.g. crop residues, green manure, slurry and farmyard manure. The second is crop rotation. A special case of the latter is "biodrilling" as targeted soil priming by plant roots (Cresswell and Kirkegaard 1995).

Haynes and Naidu (1998) give an overview of soil physical effects of organic manure addition. Higher total porosity and soil water retention over a wide range of pressure heads indicate that enhanced soil structuring upon organic fertilization resulted in both higher inter-aggregate macroporosity as well as higher volume of intra-aggregate storage pores. At low pressure heads around PWP, the increased specific surface area of soil amended with organic matter retains more water in the soil. As a consequence, hydraulic properties and processes such as air filled porosity and infiltration are improved. Organic input underlies decomposition. Temporal changes of soil aggregation are therefore linked to the turnover of organic carbon (De Gryze et al. 2006). Recent studies, however, indicated that not the chemical recalcitrance of organic residues per se, but the interaction between soil mineral particles and organic matter itself (i.e. aggregation) largely determines the mean residence time of organic substances in the soil (Schmidt et al. 2011). This is in agreement with Rawls et al. (2004) who showed that organic matter effects on soil hydraulic properties decrease with increasing initial carbon content of the soil. This fact points to the saturation of mineral surfaces, which cannot bind to further organic substances, and therefore also the hydraulically relevant process of aggregation is at steady-state equilibrium. This saturation process, however, seems most relevant for organo-mineral complexes at the microaggregate level. Evaluation of long-term fertilization trials by Blair et al. (2006a,b) showed that the increase in aggregate mean weight diameter, i.e. a higher amount of large aggregates, and related unsaturated hydraulic conductivity were most strongly influenced by the labile fraction of organic carbon. The central functional role of labile organic carbon would also explain that reduction in total organic carbon concentrations in temperate soil often did not have marked effects on soil properties (Loveland and Webb 2003), while on the contrary, substantial changes are frequently reported from fertilization trials. Stabilisation of these easily decomposable substances is linked to their physical protection from microbial degradation within aggregates as stated by the porosity exclusion principle (Dexter 1988), which in turn explains their sensitive response to management such as tillage induced turnover upon mechanical aggregate disruption.

For temperate climates, Miller et al. (2002) found significantly higher water retention and hydraulic conductivity in a clay loam soil with $17 \mathrm{~g} \mathrm{~kg}^{-1}$ total organic carbon (TOC) in a semi-arid continental climate of the Canadian Great Plains due to addition of cattle manure. Also in the above-cited studies of Blair et al. (2006a,b) with $20 \mathrm{~g} \mathrm{~kg}^{-1}$ TOC at the German site and $14 \mathrm{~g} \mathrm{~kg}^{-1}$ at the English site, organic fertilizer input improved hydraulic properties via better soil aggregation.

Experiments conducted in Mediterranean climates also found a significant improvement of soil hydraulic properties by organic matter amendment. Pagliai et al. (2004) reported a strong increase in macropores $>500 \mu \mathrm{m}$ with more elongated continuous pore channels by addition of manure and compost on a silt loam Haplic Calcisol with $12 \mathrm{~g} \mathrm{~kg}^{-1}$ TOC. The effect was most evident upon mineralisation of the organic amendments, indicating the interaction with an enhanced soil biological activity. Shirani et al. (2002) showed a strong increase in soil organic matter on an arid silty clay loam with $5 \mathrm{~g} \mathrm{~kg}^{-1}$ TOC in Iran by addition of farmyard manure, resulting in improved aggregation, lower bulk density, higher saturated hydraulic conductivity and nearly double dry matter yield of irrigated corn.

Benbi et al. (1998) and Bhattacharyya et al. (2007) studied change in soil physical properties due to organic matter addition under dry tropical conditions in India. In both cases, farmyard manure addition to soils with loamy sand and silty clay loam texture and low initial organic carbon of 2 and $7 \mathrm{~g} \mathrm{~kg}^{-1}$ TOC, respectively, enhanced aggregation, resulting in higher saturated hydraulic conductivity.

Soils in dry climates have frequently low organic matter content. Thus, addition of organic matter responds to a limiting property of these soils and can be expected to substantially improve soil physical quality. The change of hydraulic properties goes along with improved soil aggregation. Labile and particulate organic carbon fractions are responsive to management such as organic fertilization and tillage, enhance soil microbial activity and influence directly and indirectly aggregation (Bronick and Lal 2005).

There are several studies on the effect of crop rotation on soil hydraulic properties, although the direct effect of crops has been studied in less detail compared to the effects of tillage and fertilization. The important influence of crops on soil hydraulic properties is most clearly revealed when comparison relates to land use change. Generally, soil structure is more developed and more stable in forest and grassland soils compared to cropland, resulting in higher total porosity, water retention and infiltration (e.g. Francis and Kemp 1990; Schwärzel et al. 2011; Kodešová et al. 2011; Gajić 2013). This is mainly due to the higher organic carbon in forest and grassland soils. Plant roots are a key factor influencing soil hydraulic properties in different crop sequences. Their 
qualitative role for soil structure and hydrology is well known from the hierarchical models of aggregation and porosity (Tisdall and Oades 1982; Elliott and Coleman 1988) as well as from field soil surveys showing a crumby, loose and macroporous structure in densely rooted soils (e.g. Rampazzo and Mentler 2001). Our focus here is on cropland. We will first address the role of crop rotation in general; then, we specifically discuss the concept of root induced biodrilling.

For crop rotation experiments in temperate climates, Dexter et al. (2001) found higher water retention and hydraulic conductivity in a loamy sand soil in Poland when including a cover crop such as mustard or clover/grass mixtures in the crop rotation. Carof et al. (2007) showed that under no-tillage cover crops enhanced pore continuity in a silt loam in northern France, while Bodner et al. (2008) found that cover crops stabilised effective pore properties over winter on a silt loam soil in semi-arid Eastern Austria. Villamil et al. (2006) studied the effect of inclusion of rye, vetch and vetch/rye mixture as cover crops in a corn-soybean notillage rotation on a silt loam soil in Illinois, USA, with a continental summer rainfall climate. Cover crops increased organic carbon, aggregate stability and water holding capacity, while reducing bulk density and penetration resistance. Głąb et al. (2013) compared long-term effects of different crop rotations, i.e. sugar beet-spring triticale-faba bean-winter triticale; spring triticale-winter triticale-oat; winter triticalespring triticale, on soil hydraulic properties for a loam soil in southern Poland. They found significant change in water retention properties by crops, with triticale enhancing plant available water. However, the crop effect was not stable over time and no long-term crop rotation effects could be demonstrated. McVay et al. (2006) reported effects of tillage and crop rotation from five trials in a continental climate in Kansas, USA, all having silt loam soils. Changes were found only in the upper soil layer from 0 to $5 \mathrm{~cm}$. Crop rotations with cereals increased soil organic carbon, but compared to tillage intensity did not have a significant effect on water holding capacity.

Blair et al. (2006c) evaluated a long-term crop rotation experiment on two clay-rich Vertisols under semi-arid conditions in Australia. More frequent inclusion of forage legumes (Medicago sativa L.) in the rotation enhanced aggregate mean weight diameter and hydraulic conductivity due to higher soil organic carbon. In addition, Armstrong et al. (1999) found higher hydraulic conductivity and enhanced macroporosity in a clay soil in Australia under legumes compared to sorghum. Miglierina et al. (2000) reported enhanced water holding capacity from a long-term rotation trial on a sandy loam in semi-arid Argentina when including a vetch as legume component in a wheat-based cropping system. Masri and Ryan (2006) found higher organic matter, aggregation stability and infiltration due to legumes such as $M$. sativa $\mathrm{L}$. and $V$. faba L. in a durum wheat based cropping system compared to traditional wheat-fallow and continuous wheat rotations on a clay soil in Syria with a dry Mediterranean climate.

Also under tropical conditions, improved water retention and transmission properties in legume-based rotations were reported by Bhattacharyya et al. (2006). Effects in the sandy clay loam site, however, were mainly evident in the no-tillage system. Chenkual and Acharya (1990) compared rice-wheat and maize-wheat rotations on a silt clay soil in India. Maize enhanced hydraulic conductivity and profile water storage compared to rice, which they related to different soil drying.

We notice here that, in a meta-study of Hathaway-Jenkins et al. (2011), no differences were found between conventional and organic farming systems. Similar to other management measures, also crop rotation studies reveal the importance of the time scale of changes (Głab et al. 2013). A transient crop impact can be overlaid by several environmental factors such as wet-dry and freeze-thaw cycles or raindrop impact that commonly shape soil hydraulic properties (Logsdon et al. 1993; Bodner et al. 2013).

A main causal factor for the observed changes in hydraulic properties reported by several crop rotation studies were changes in soil organic carbon. Much less attention was put on the direct role of plant root traits for hydraulic properties. Still, there is an increasing interest on capturing the impact of different root systems on soil physical properties to eventually allow their targeted management. In more recent times, this work was pioneered by Cresswell and Kirkegaard (1995) who established the concept of primer plants to biologically improve soil porosity for subsequent plant growth. Although their early experiments with canola for biodrilling hardened subsoil in Australian did not show significant impact, several follow-up studies have been done, which were resumed by Yunusa and Newton (2003). Generally, we can identify two targets of root-induced soil priming: Remediation of natural or management induced physical constraints such as subsoil compaction, and improvement of soil structure related pore properties with relevance for cropping systems, i.e. water transmission and storage pores.

Stirzaker et al. (1996) reported improved barley root penetration through a compacted soil layer via biopore channels created weather artificially or by ryegrass and lucerne. Nuttall et al. (2008) considered that primer plants with a highly branched root systems, e.g. Lotus corniculatus L. or Hedysarum coronarium L., leave a biopore mosaic that allows better subsoil water extraction of a subsequent wheat crop compared to a less branched and coarser biopore geometry after lucerne. Williams and Weil (2004) showed the positive effect of radish cover crop roots penetrating a compacted layer and creating growth paths for a subsequent soybean. Among different cover crops, radish had higher potential to penetrate through dense compacted layers compared to rapeseed and rye (Chen and Weil 2010). Perkons et al. (2014) measured higher root length density of main crops such as wheat, barley and 
rapeseed in deep soil following a taproot species compared to a fibrous rooted pre-crop and related this to enhanced largesized biopores. Stirzaker et al. (1996) mentioned the problem of root-soil contact for roots growing in large biopores. White and Kirkegaard (2010) studied this problem in detail, showing that wheat roots growing in biopores interacted with surrounding soil by root hairs, while roots growing in cracks had reduced root hair formation. Athmann et al. (2013) showed that plants growing in biopores establish contact to soil either by growing along the pore wall (barley) or via lateral roots (rapeseed). The capacity of primer plants to alleviate soil compaction depends strongly on the degree of compaction. In case of intermediate compaction levels, tap-rooted crops with strong root mechanical resistance against buckling (Clark and Barraclough 1999) and perennial forage legumes (Lesturgez et al. 2004) can be sufficiently effective. In case of strong compaction or naturally hardset horizons, woody species (Yunusa et al. 2002; Bartens et al. 2008) would be required to effectively improve penetrability of these layer for subsequent crops.

Beyond biopore creation in dense layers, roots can be targeted as a natural management tool for soil structural porosity to enhance water holding capacity as well as saturated hydraulic conductivity. Although there is an increasing knowledge on root-soil structure interactions (cf. Section 2.4), which has substantially advanced due to modern 3D-imaging methods, there is still a significant gap between process analysis at the single root scale and upscaling to the cropping system. Some findings in crop rotation studies (e.g. Dexter et al. 2001), however, clearly suggest that roots are directly involved in the improvement of hydraulic behaviour at the field scale. Rasse et al. (2000) showed the higher macroporosity and saturated hydraulic conductivity as a result of alfalfa root penetration and enhanced wet-dry cycles in the rhizosphere. Bodner et al. (2014) provided evidence for the impact of cover crop roots on the soil pore size distribution. They revealed that root growth influenced different pore size classes and that root systems dominated by coarse, e.g. legume, and fine, e.g. brassica, root axes had distinct impact on hydraulic properties. The authors suggested mechanisms at the root-soil interface underlying their macroscopic observations. There is still need for further field scale studies that provide quantitative relations between root traits, soil structure and hydraulic properties and their effects on a subsequent crop. A resume of the role of organic matter and plant roots on soil hydrology is given in Box 4.

Box 4: Organic matter and plant roots: biological effects on soil hydrology

Organic fertilization and crop species influence soil hydrology. Although these effects are weaker compared to tillage, clear crop effects are found for lighter soils and by inclusion of legumes in the crop rotation. Crop effects are strongest in no-tillage systems, while soil mechanical disturbance overlays the crop influence on hydraulic properties. Organic substances themselves influence water storage. Their main function is via soil structure and structural porosity. Crop rotation effects, e.g. cover crops vs. fallow, are often related to different levels of organic matter input. In addition differences in root system properties and their turnover dynamics are relevant factors for hydraulic properties, pore stabilisation and improved subsoil exploration by subsequent crops.

\subsubsection{Plant-related measures}

Roughly, we can distinguish between crop stand management and measures related to breeding. Stand management provides short term adaptation by optimising seeding date and stand density. Besides classical field experiments, today SPAC models provide efficient tools for in silico experiments to optimise site specific cropping system design and adaptation (e.g. Messina et al. 2006; Chenu et al. 2011; Jeuffroy et al. 2014). Breeding is an immediate option when referring to the choice among existing cultivars differing in drought resistance. A long-term adaptation could be expected from ongoing breeding research. This distinction is certainly somewhat arbitrary as also existing cultivars are a result of previous research and breeding work. Therefore, we distinguish between morphological adaptation, e.g. via plant height and harvest index, and phenological adaptation, e.g. via earliness, as the predominant selection strategy of past breeding efforts, on the one hand, and change of secondary physiological traits, on the other hand, that is still largely at the stage of research.

\subsection{Short term measures}

\subsubsection{Early sowing}

Under dry conditions, optimisation of seeding time is a key measure to match plant demand with water availability. This measure interacts with earliness as breeding trait to escape dry periods. Here, we will just refer to the hydrological impact of changed seeding time, while other related issues, e.g. phytosanitary aspects or frost damage risk, are not discussed. There can be three main reasons for early sowing in dry environments: (i) seasonal variation in evaporative demand improves water-use efficiency of early (winter) sown crops/ cultivars because part of their growth takes place under lower water potential gradients to the atmosphere (cf. $E T_{0}$ in Eq. 6; e.g. Brown et al. 1989); (ii) early seeding shifts sensitive stages such as flowering and grain filling to periods of better water availability (e.g. Herrero and Johnson 1981); and (iii) deeper rooting of early sown crops improves avoidance of early droughts (Barraclough and Leigh 1984; Brown et al. 1989; Incerti and O'Leary 1990).

Ehlers and Goss (2003) reported higher yield of early sown winter wheat and winter barley on a light soil in the 
continental semi-arid climate of Eastern Germany. Particularly on drought prone low storage soils, earlier sowing results in better water availability at flowering and grain filling (Boese 2010). Schwarte et al. (2006) showed an optimum curve for seeding date of triticale in continental semi-arid Iowa, USA, requiring $533{ }^{\circ} \mathrm{C}$ days before winter to obtain highest yield potential. Kirkland and Johnson (2000) tested alternative seeding dates, i.e. fall and April, compared to traditional May sowing for rapeseed at a continental site of the Canadian prairie where hot dry weather frequently affects flowering. The earlier sowing date provided on average $38 \%$ yield advantage due to better flowering and grain filling. Berzsenyi and Lap (2005) and Berzsenyi and Dang (2008) studied the effect of sowing date on maize yield in the semi-arid temperate climate of Eastern Hungary. Early sowing reduced yield stability, while late sowing resulted in lower yield potential. In years with favourable spring conditions, early sowing produced highest yields. Generally, a trend towards earlier sowing can be expected considering long-term climatic shifts (Cutforth et al. 1999; Lavalle et al. 2009).

Turner (2004) reviewed measures for sustainable crop production under drought in Mediterranean climates. He attributed half of yield improvement over the last decades to agronomic measures, mainly advanced sowing time and fertilization both leading to higher early vigour and better match of water availability with crop demand. Eastham et al. (1999) showed that early sowing of wheat and lupine significantly enhanced overall water use and reduced the energydepended first stage soil evaporation due to better soil coverage. Mahdi et al. (1998) determined a yield loss of $5 \%$ per week for durum wheat when sowing was delayed after first of November in Syria. However, sowing too early resulted in suboptimum stand establishment due to the lack of moisture for homogeneous germination and emergence. In addition, Latiri et al. (2010) reported better wheat yield in Tunisia with early sowing for years with no stress at germination. GomezMacpherson and Richards (1995) investigated yield effects of sowing date at three Australian sites. Early sowing increased biomass but not yield, suggesting that there was higher competition for assimilates between vegetative and generative sinks. Particularly under dry conditions, grain yield is often sink limited (Duggan et al. 2000; del Moral et al. 2003) and depends strongly on a high number of kernels per spike and kernel weight per spike (Denčić et al. 2000). Higher vegetative biomass may impair the optimum formation of these yield components in summer-dry climates. For faba bean under dry Mediterranean conditions of Australia, Loss et al. (1997) on the contrary showed that early sowing improved water use during grain filling. Early sown plants escaped drought and increased number of pods per square metre and seed weight (Adisarwanto and Knight 1997).

Under dry tropical and subtropical conditions, it is particularly important to match water availability with crop demand to complete most phenological stages before onset of the dry season. Both field experiments and modelling studies showed that rainfed rice production is mostly influenced by drought escape via appropriate seeding date and/or earliness of cultivars (Fukai et al. 1998). Sial et al. (2008) compared yield components and yield of wheat mutant lines in response to seeding time in Pakistan. A shorter and more stress prone grain filling period decreased yield around $50 \%$ for later sowing dates. Dzotsi et al. (2003) used a simulation model to study optimum sowing date of maize in Southern Togo during the main and secondary rainy season. In both cases, early sowing improved yield. Additionally, very early cultivars were required during the shorter secondary rainy season. Box 5 resumes the role of sowing date for crop water management.

Box 5: Early sowing: synchronisation of supply and demand

Optimisation of sowing date is a main requirement for crop management in dry regions. Changes in traditional sowing dates often came along with changes in crop rotations and new cultivars. Early sowing dates are most important in climates with a distinct dry season to escape terminal drought, while they are less effective in case of intermittent drought. Under temperate continental climates, sowing date has a rather broad optimum, while drastic yield effects are reported from climates with distinct dry season. Increasing yield by early sowing requires appropriate conditions for optimum stand establishment and early vigour. Other management measures like deeper sowing and seed priming may be required in case of risk for dry conditions at early sowing dates.

\subsubsection{Reduced stand density}

Reducing stand density aims to a reduction of intra-specific competition and enhanced water availability to the single plant. Particularly, water availability for the post-flowering period should be improved to optimise yield formation under conditions of limited in-season rainfall. While early sowing is an agronomic measure of drought escape, reduced stand density is related to water saving. The main disadvantage related to lower stand density is an increase in evaporation losses and possibly also higher runoff, particularly for wide-row crops. The effect on yield is complex and involves modified radiation use, changes in source-sink relations and assimilate translocation. Particularly, cereals have high plasticity in yield formation with mutual compensation between yield components. Ehlers and Goss (2003) still noted a rule that generally applies: the drier the situation, the lower the optimum stand density. Beside lower stand density, i.e. less plants per square metre, also changes in plant spacing for a given density is discussed here as it also aims to reduce intra-plant competition.

For the semi-arid region of Eastern Germany with frequent moisture deficit during grain filling, Waloszczyk (1991) reported higher yield stability for lower stand density of winter 
wheat with 300 plants $\mathrm{m}^{-2}$ at a relatively high average yield level of $8.1 \mathrm{Mg} \mathrm{ha}^{-1}$. This was mainly due to higher harvest index and probably depletion of moisture by more straw biomass in denser stands. Under dry continental conditions in Montana, USA, at an average yield level of $3.3 \mathrm{Mg} \mathrm{ha}^{-1}$, Chen et al. (2008) found an optimum seeding density of spring wheat at 215 seeds $\mathrm{m}^{-2}$ with highest kernel weight and high number of kernels per spike. Particularly, under drier conditions, higher seeding rates resulted in the loss of all secondary tillers. McKenzie et al. (2005) investigated different seeding rates of spring barley under semi-arid continental conditions of Southern Alberta, Canada. Yield with an average level of $4.4 \mathrm{Mg} \mathrm{ha}^{-1}$ slightly increased with higher seeding rate from 150 to 350 seeds $\mathrm{m}^{-2}$, while kernel weight and protein content decreased. In a similar climate in Saskatchewan, Tompkins et al. (1991) found that narrow row spacing and higher seeding density improved yield, preanthesis water use and overall water-use efficiency. For row crops, Sárvári (2005) found that optimum plant density of maize in semi-arid Eastern Hungary was strongly dependent on the cultivar and varied between 6.5 and 9.0 plants $\mathrm{m}^{-2}$. Above optimum densities reduced yield and yield stability. For sugar beet, Ehlers and Goss (2003) reported that seeding densities in semi-arid and humid regions of Germany were similar. They explained this by reduced leaf re-growth during the later season due to water shortage thereby reducing assimilate competition between leaf and beet.

For a summer-dry climate of Inland Pacific Northwest, USA, Schillinger (2005) found no differences in yield of spring wheat, barley and oat due to varied seeding rate at an average yield level of $2 \mathrm{Mg} \mathrm{ha}^{-1}$. Arduini et al. (2006) found highest yield in durum wheat at highest density with levels of 200,250 , and 400 seeds $\mathrm{m}^{-2}$ in Italy at a yield level of about $6 \mathrm{Mg} \mathrm{ha}^{-1}$. Higher seeding density increased post-heading assimilate translocation from vegetative parts to grain. When increasing seeding density from 225 to 340 seeds $\mathrm{m}^{-2}$, Fang et al. (2010) measured increased grain yield of winter wheat in a terminal drought environment in China during wetter years with average yield level of $6 \mathrm{Mg} \mathrm{ha}^{-1}$, while in drier years with average yield level of $3.5 \mathrm{Mg} \mathrm{ha}^{-1}$, the contrary trend was observed. Soil water content was lower under high seeding density and post-heading dry matter accumulation and assimilate translocation increased. Kleemann and Gill (2010) investigated the effect of increased row spacing of spring wheat in Australia from 18 to $54 \mathrm{~cm}$ in order to conserve soil moisture for grain filling. However, they did not find higher post-flowering water use for larger row spacing to avoid significant yield decrease from 2.9 to $2.3 \mathrm{Mg} \mathrm{ha}^{-1}$ due to reduced radiation interception. Overall, WUE was lower in treatments with wider row spacing. Barbieri et al. (2012) found a higher yield of maize when reducing row spacing from 70 to $35 \mathrm{~cm}$. Narrower rows increased early season evapotranspiration and overall water-use efficiency. Similar results were reported by
Sharratt and McWilliams (2005) from Michigan, USA, who also found more even root distribution and significantly higher radiation interception of narrow spaced maize. Also for faba bean, Silim and Saxena (1993) reported improved radiation and water use, higher dry matter and yield leading to overall higher water-use efficiency with narrow row spacing and higher seeding rate in a dry Mediterranean climate in Syria.

Simmonds and Williams (1989) observed that higher seeding density in groundnut in India slightly decreased evaporation, while increasing transpiration mainly during the vegetative stage. Dense stands enhanced water extraction from deep soil layers. Buah and Mwinkaara (2009) compared the yield at different densities of sorghum in the Guinea Savanna zone at average yield levels of $2 \mathrm{Mg} \mathrm{ha}^{-1}$. There was no significant yield difference between densities of 5 and 13 plants $\mathrm{m}^{-2}$. Huda (1988) on the contrary reported a higher sorghum yield when increasing plant density from 2 to 16 plants $\mathrm{m}^{-2}$ in India. Pearl millet is a frequently cropped tillering tall cereal under dry tropical conditions. Generally, it is planted at low density to reduce the risk of crop failure via staggered development of main stem and tiller panicles. De Rouw (2004), however, showed that an intermediate plant density of $1 \mathrm{hill} \mathrm{m}^{-2}$ with three plants per hill increased the frequency of higher yields in the Sahel. The overall role of stand density under different hydrological conditions is resumed in Box 6.

\begin{abstract}
Box 6: Stand density and water saving
Yield is most responsive to lower stand density when water saving for improved grain filling is effectively obtained. Therefore, yield effects are strongly dependent on site conditions. At lower stress levels in temperate and some Mediterranean sites, higher densities often provide a yield advantage, particularly for crops that cannot compensate low seeding density via increased fertile tillers or branches when water supply is sufficient. At sites with intense water stress and very low yield level, similar yields are obtained over a range of seeding densities, indicating that changes in inter-plant competition do not determine significantly yield. It appears that under intermediate terminal stress levels, water saving by lower stand density is most effective to optimise yield. The increase in soil evaporation by lower density and/or wider row spacing depends on rainfall frequency and is higher for an intermittent drought pattern compared to a prolonged dry period. Beside evaporation, reduced radiation interception by sparse stands might limit growth and increase weed competition with crop plants.
\end{abstract}

\subsubsection{Breeding in the past—phenology and partitioning}

Breeding has contributed to increase yields in dry regions with an average of $0.2 \%$ per year. However, progress was less compared to high yielding environments with $2.9 \%$ per year (Trethowan et al. 2002). Reynolds et al. (2007) estimated that a $2 \%$ yield increase per year of wheat is required to meet rising global food demand. 
For small grain cereals, Slafer and Araus (2007) pointed to semi-dwarfism as a major change in cereals that led to improved yield in stressful environments. They considered that breeding has led to an optimum stature of cultivars, and therefore, selection for plant height provides few possibilities for future improvement. Further reduction of plant height on the contrary would lead to poor radiation use efficiency. The contribution of harvest index to yield improvement was documented in several retrospective studies. Shearman et al. (2005) found a linear correlation of yield and harvest index for wheat in the UK until 1983. Thereafter, yield increase was related with higher preanthesis growth rate and soluble carbohydrates in the stem together with higher grain number per square meter, i.e. higher sink strength. Aisawi (2012) found harvest index to explain yield increase of $0.59 \%$ per year in a CIMMYT germplasm collection between 1966 and 1990. Thereafter, increase was associated with the length of grain filling period. A similar result was found by Sadras and Lawson (2011) for Australia. Harvest index increased linearly for cultivars released between 1958 and 2007. Yield gains after the 1980s were associated with higher crop growth rate due to better radiation use efficiency, possibly related to increased stomata conductance and/or greener leaves. Furthermore, enhanced carbon translocation has substantially contributed to better grain filling. Araus et al. (2008) resumed from retrospective studies that there was low change in total biomass, while mainly optimisation of partitioning assimilates provided steady yield increase in small grain cereals. For Mediterranean environments, Álvaro et al. (2008) and Isidro et al. (2011) also found a breeding trend to earlier heading in Spanish and Italian durum wheat cultivars.

Maize also had higher historical yield increase in well watered compared to stress environments (Campos et al. 2004). Under stress, yield gains were mainly associated to shortening of the anthesis-silking interval (ASI) and longer green leaf area duration, commonly known as "stay green". In a retrospective study on temperate maize cultivars released in Canada between 1950 and 1980, Tollenaar and Wu (1999) found enhanced resource capture under stress by higher leaf longevity, more active roots and better assimilate translocation to grains. Tollenaar and Lee (2002), therefore, concluded that main yield gains in maize were not due to higher yield potential or heterosis per se, but were mainly based on better stress tolerance. Campos et al. (2006) tested traits related to yield progress in the US Corn Belt for Pioneer cultivars released between 1953 and 2001 and found shorter ASI to best explain better performance under water stress. Tokatlidis and Koutroubas (2004) showed that better stress resistance in modern cultivars is related to the high planting densities required for high yields. In a US study, also Duvick (2005) revealed that yield potential per plant has not increased between 1934 and 2004. Newer hybrids yielded more than older ones because of higher ability to withstand the stress associated with higher plant density. Using a model to explain historic yield trends in US maize, Hammer et al. (2009) found changes in root architecture associated with higher water uptake to be the main reason for better abiotic stress resistance. For tropical maize, Bolaños and Edmeades (1996) found ASI to be the most relevant breeding trait for better drought resistance. Furthermore Monneveux et al. (2006), testing two CIMMYT populations, confirmed that ASI and generally improved partitioning of assimilates to the ear after flowering had highest impact for better yield under tropical dry conditions.

For tropical and subtropical dry regions, sorghum and pearl millet are important crops aligned to longer breeding programs. As average yield level in Africa and Asia is still low (600-900 $\mathrm{kg} \mathrm{ha}^{-1}$ ), breeding as well as improved management provide huge potential for yield increase. Furthermore, there is high diversity of available germplasm (e.g. Ali et al. 2008). Yield potential has substantially increased with the introduction of hybrids. Rai et al. (1999) and Yadav et al. (2012) mentioned higher harvest index and earliness as key traits for improved drought resistance of pearl millet cultivars from routine breeding programs, while for sorghum, in addition to earliness, also stay green types have contributed to better yield in dry environments (Reddy et al. 2009). Box 7 resumes achievements of past crop improvement and points to the need for new approaches.

Box 7: Crop improvement for drought resistance at a crossroad?

Crop improvement has achieved substantial yield advances of existing cultivars for dry environments, although to a lower extent than for nonstress environments. Species with long tradition in breeding like small grain cereals have been optimised over several decades. Substantial yield gain has resulted from improved stature, i.e. mainly harvest index, and adaptation of phenology to escape post-flowering drought. However, breeding progress from selection for these traditional traits has slowed down. In maize, successful selection traits were shorter ASI and stay green, with improved rooting leading to better drought avoidance. Crops with more recent breeding history and low yields in dry regions such as pearl millet and sorghum still offer potential for improvement based on traditional morphological and phenological adaptation. The necessity of new approaches for crops with long breeding history, better knowledge of drought resistance mechanisms and new screening tools increasingly popularise integration of secondary traits in breeding research.

\subsubsection{Breeding for the future-long-term measures}

Long-term measures at the plant level strive to overcome current physiological limitations to growth and yield production under drought. Introduction of $\mathrm{C}_{4}$ photosynthesis into $\mathrm{C}_{3}$ plants is still an ultimate aim among some plant physiologists (e.g. Leegood 2002). However, there seem to be several opportunities for improved growth under water shortage that are 
more likely to disseminate from research to practical breeding (e.g. Reynolds and Tuberosa 2008; Reynolds et al. 2009; Lopes et al. 2011). Cattivelli et al. (2008) considered three approaches as decisive for future breeding: physiology, molecular genetics and molecular biology. For crop ecology, the focus is on exploiting biodiversity in physiological traits at the plant level, which are involved in regulating water flow through the SPAC. We will give some examples how physiological mechanisms of stress resistance that were introduced in Section 2.2 have been used in a breeding context. The integration of physiological traits into breeding is mainly dependent on efficient screening methods. There is an increasing number of promising tools that could facilitate crop improvement via better physiological characterisation (e.g. Nakhforoosh et al. 2013).

\subsubsection{Breeding for dehydration avoidance}

Dehydration avoidance can be achieved by water saving and water spending. Water saving due to higher intrinsic water-use efficiency has been popularised in breeding research with the introduction of carbon isotope discrimination (CID) as an easily measurable parameter in the mid-1980s (Farquhar and Richards 1984). CID has been assessed for various crops such as $\mathrm{C}_{3}$ cereals (Araus et al. 2002), maize (Gresset et al. 2014), soybean (Gitz et al. 2005), sorghum (Henderson et al. 1998), faba bean (Link et al. 2007) and others. CID is an indicator of conservative water use and related to earliness. It is therefore an important breeding trait for environments with terminal drought (Condon et al. 2004; Monneveux et al. 2005). Higher intrinsic water-use efficiency can be related to both reduced stomata conductance and higher photosynthetic capacity. The latter would combine water saving with high yield potential, but is considered to be less variable in plants beyond different photosynthetic pathways. Leaf chlorophyll concentration (Rao et al. 2001; Sheshshayee et al. 2006) and specific leaf area (Rao et al. 1995; Richards 2000), however, are proxies for selection of genotypes with high intrinsic water-use efficiency mediated by superior photosynthetic capacity.

Measurement of leaf temperature has been used as a screening trait for sustained plant water supply (Blum et al. 1982) instead of direct measurement of stomata conductance. In their original work, Blum et al. (1982) used leaf temperature to screen for superior drought resistance of wheat. Mori et al. (2011) used infrared thermography to analyse differences in root water uptake associated with a water-saving behaviour of wheat in a Mediterranean climate. Hirayama et al. (2006) showed the strong negative correlation of leaf temperature with transpiration and photosynthesis in upland rice. Liu et al. (2011) demonstrated the relation between leaf temperature and drought tolerance for maize. Jones et al. (2002) studied stomata closure in grapevine by infrared thermography.
Since the 1990s spectral reflectance measurement has been increasingly used as screening approach for the tolerance of various stresses (Carter 1993; Peñuelas and Filella 1998). For example, Winterhalter et al. (2011) estimated canopy water mass of tropical maize hybrids based on spectral reflectance and showed that it can be used as a high throughput tool to discriminate between groups with different drought resistance. Gutierrez et al. (2010) gives an overview of the relation of spectral indices such as NDVI, NDWI and WI to plant water status measured by relative water content and/or leaf water potential in different wheat genotypes. Araus and Cairns (2014) reviewed currently available spectral technology and their use for field phenotyping. Beside plant water status, reflectance indices are also used to predict other plant properties, such as biomass growth and yield (e.g. Aparicio et al. 2000; Ma et al. 2001) and nutritional status of crops (e.g. Filella et al. 1995; Graeff and Claupein 2003; Xue et al. 2004).

Water spending by improved uptake has been shown to be an essential trait for better drought resistance, particularly for intermittent stress. Efficient uptake of water addresses the root system as essential breeding target (Vadez et al. 2007). Still, there are only few examples where root traits have been targeted in breeding programs. Systematic breeding efforts for root system properties have been done mainly for rice (Price et al. 2002; Kato et al. 2006; Farooq et al. 2009a) and chickpea (Kashiwagi et al. 2005; Gaur et al. 2008). For wheat, physiological and root research studies evidence the significant contribution of roots to higher drought resistance (e.g. Sanguineti et al. 2007; Manschadi et al. 2008; Palta et al. 2011). Wasson et al. (2012) give an overview of selection strategies for root improvement of wheat in Australia. The lack of breeding activities on roots is mainly related to the measurement problem, as there are few fast and cheap screening methods. Existing high throughput approaches are mostly indirect (e.g. Středa et al. 2012) or ex situ (e.g. Hund et al. 2009b). Still, roots are promising targets as (i) they are less exploited compared to aboveground traits, (ii) most root traits are compatible with high yield potential and (iii) there is considerable diversity (Trethowan and Mujeeb-Kazi 2008; Lopes and Reynolds 2010; Nakhforoosh et al. 2014). Recently, there is an increasing effort to establish high throughput root phenotyping platforms to advance in targeted root breeding (Nagel et al. 2012).

\subsubsection{Breeding for dehydration tolerance}

Dehydration tolerance is a relevant trait for environments with intense water stress such as tropical semi-arid and arid regions. Here, we emphasise on osmotic adjustment and cell membrane stability as two widely used approaches to improve dehydration tolerance in crops that have been used in breeding research. Osmotic adjustment is a key response of plants to maintain cell turgorescence under conditions of reduced water 
availability. By lowering osmotic potential, they increase the water potential gradient to soil and thereby maintain water uptake and expansive growth for longer time. Furthermore, osmotic adjustment enhances root elongation in dry soil. An overview of measurement methods for osmotic adjustment is given by Babu et al. (1999). Blum (2005) considered osmotic adjustment to be a main breeding target for stress resistance due to its compatibility with high yield potential. A different opinion on the role of osmotic adjustment has been expressed by Munns (1988) and Serraj and Sinclair (2002) considering that, beyond the beneficial maintenance of root growth, osmotic adjustment is only effective as survival mechanism under severe drought, i.e. under stress intensities beyond the feasibility of rainfed crop production. Turner et al. (2007) did not find better yield of chickpea under terminal drought due to osmotic adjustment. Sánchez et al. (1998) found that osmotic adjustment partially explained turgor maintenance in pea cultivars under drought leading to higher yield. Jongdee et al. (2002) could not find a direct relation between variation in osmotic adjustment among rice genotypes and their yield performance under drought. Chimenti et al. (2002), on the contrary, reported that sunflower cultivars with higher capacity of osmotic adjustment had better yield under drought. For wheat, Fischer et al. (2005) found a positive relation between osmotic adjustment and yield for the highest stress level they tested.

Another approach associated with severe drought conditions is cell membrane stability (Blum and Ebercon 1981). It can be readily assessed by electrolyte leakage (e.g. Bajji et al. 2002) and is related to the concentration of compatible solutes like proline (e.g. Valentovic et al. 2006). Singh et al. (1992) found a correlation of yield of wheat genotypes under dry field conditions and their differences in cell membrane stability under PEG-induced stress. Akbarian et al. (2011) measured proline among other physiological traits in triticale under tropical terminal drought conditions in India and reported significantly lower yield losses with higher proline concentration. Studies on membrane stability were frequently done under osmotically induced stress (e.g. Lauriano et al. 2000) and using young plants (e.g. Zlatev et al. 2006). While they revealed important mechanisms and solutes underlying increased membrane stability, a direct relation between these indicators and yield of drought stressed rainfed crops in the field has to be taken with care. Particularly for dehydration tolerance traits, a clear definition of the targeted stress environment is of key importance to evaluate their potential use for crop improvement. Box 8 highlights the potential of secondary traits for future breeding advance.

\section{Box 8: Secondary traits for drought resistance breeding}

Breeding research for secondary physiological traits has shown potential for better stress resistance in water-limited environments. A bottleneck is high throughout phenotyping, which has been successfully resolved only for some traits of potential interest. Mainly drought avoidance via the root system still suffers from a lack of screening methods. A challenge for the inclusion of new physiological traits to crop improvement is to ensure their compatibility with high yield potential. While yield constitutes a universal target trait for all environments, physiological parameters require a precise understanding of the drought environment to estimate their potential role for better crop performance. Therefore, experimental design is particularly critical and extrapolation of results from artificial laboratory conditions, such as shock stress and small juvenile plants to the field has to be taken with care.

An overall estimate of the efficiency of all reviewed management measures for crop water supply under different climatic conditions is given in Fig. 9.

Among agronomic measures tillage system, influencing both surface mulch cover and soil porosity, together with optimised seeding dates to match water supply and demand, are considered most effective. While tillage-induced effects on soil hydraulic properties are similar under all climates, the water-saving potential of mulch depends on the importance of evaporation losses with highest efficiency under storage driven Mediterranean conditions. Stubble tillage is relevant to reduce post-harvest evaporation mainly when some relevant amount of rainfall occurs during the fallow period. However, the overall efficiency is limited. Managing initial water depletion via crop rotation measures, e.g. cover cropping vs. fallow, biennial rotations vs. fallow years or well balanced wet and dry season crops, is of increasing importance the more a crop depends on stored soil water. Therefore, the initial depletion level is crucial for dry season crops in tropical and subtropical residual moisture regimes. The importance of organic matter input for better soil water storage increases with decreasing soil organic matter content. Compared to strong changes in soil porosity from mechanical interventions via tillage, biologically mediated measures are more complex. Still, they are a key for sustaining soil physical quality and therefore integral part of any conservation tillage system.

Timely sowing is most important in climates where crop growth partially or largely coincides with a dry season. The yield increasing effect of optimised sowing dates is very consistent. Yield improvement via reduced stand density on the contrary can be nullified by morphological plasticity of crops and risk of suboptimum light use.

Breeding for adapted phenology and optimum assimilate partitioning underlies much of yield improvements in waterlimited environments. Among new target traits for future breeding, we consider an effective root water uptake as a key for success with importance for most dry ecosystems. Crops grown under high intensity and continuous drought conditions, such as during post-monsoon dry season in residual moisture environments, can profit from water saving providing a balanced water use between vegetative and generative phase. Owing to the prolonged stress periods, they also need sufficient dehydration tolerance to sustain their metabolic functioning for yield formation and avoid crop failure. 
Fig. 9 Efficiency of agronomic and breeding measures under different drought regimes. Stress increases from supply driven to residual moisture regimes. Dark colours indicate high efficiency, while light colours show low efficiency in a given drought regime. The size of bars furthermore indicates which measures are expected to be most effective

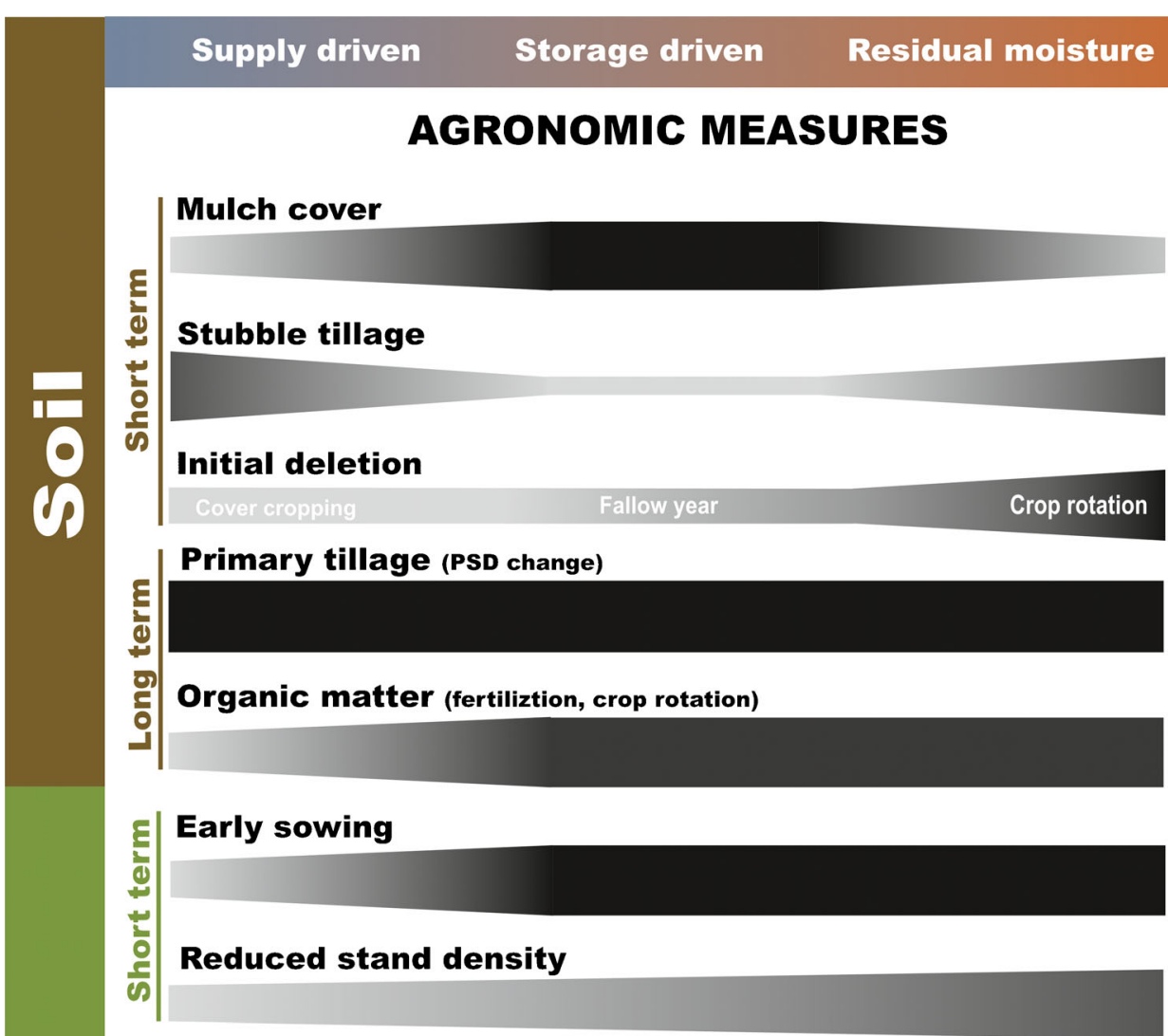

BREEDING MEASURES
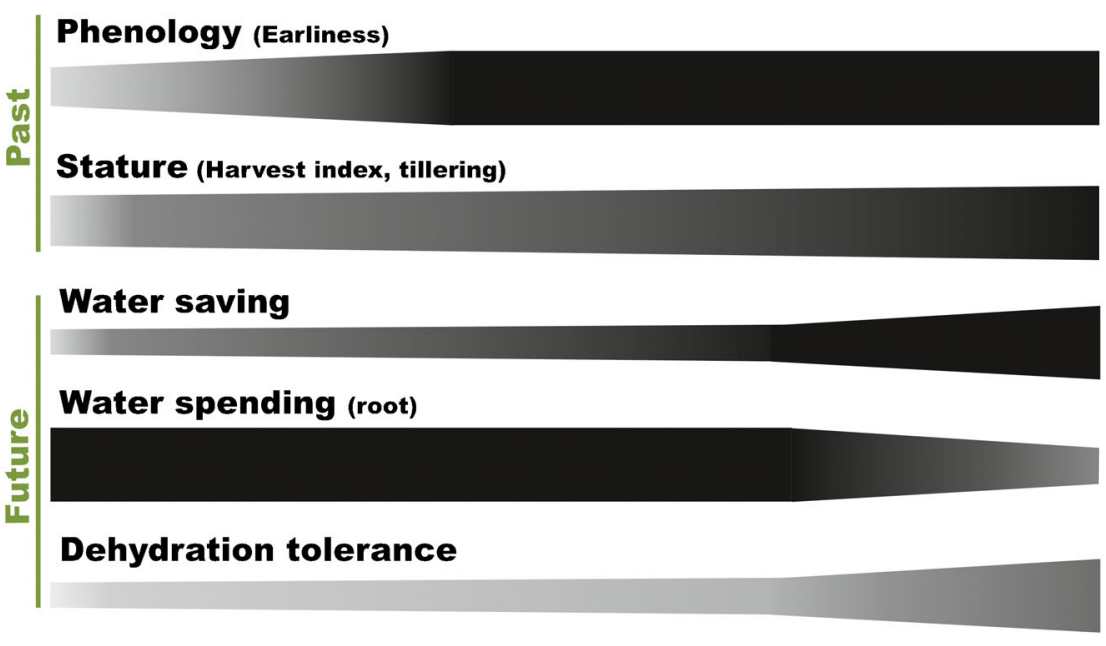

\section{Conclusions}

This work has identified challenges and options for an efficient crop production in water-limited ecosystems. Our analysis provides an ecological approach to agricultural water management: We consider that a cropping system can be most efficiently improved when measures are based on a precise identification of the main yield limiting constraints in the climate, soil and plant subsystems. Crop ecology thereby integrates ecohydrological and ecophysiological knowledge into cropping system diagnosis. Given the global limits of further cropland extension and blue water use to increase food production, attention should be directed towards soil-plant feedback processes to sustain the FAO strategy of sustainable crop production intensification via higher resource use efficiency. 
From our review of approaches to improve crop production under limited green water availability, we conclude that we can expect most progress when focussing on these feedback processes. This is particularly valid when considering the possible contribution of science to meet future challenges in agricultural production. Classical measures of cropping system adaptation to the prevailing stress environment such as sowing time and density today are rather a question of extension than science: They have to be adjusted to the local hydrological conditions and to the existing socio-economic reality of farmers practices. The challenge lies mainly in the diversity of environments interacting with management. This can be addressed efficiently using SPAC models for cropping system design. Therefore, we claim that it is just a question of time that traditional approaches to improve dryland cropping systems are approaching their limits. Climate-soil-plant feedback processes on the contrary are still a hardly exploited field with potentially high relevance for cropping systems. Feedbacks are a scientific challenge: They involve complex physiological signalling/response cascades in the plant and dynamic biologically mediated physico-chemical reactions in the soil. Although a lot of feedback mechanisms with potential interest for crop production are well known, e.g. rootssoil structure, and knowledge is quickly increasing with new non-destructive 3D imaging tools such as X-ray micro-tomography, we are still far from understanding their real importance for crop yield beyond hypothetical claims and knowing how to manage them effectively at the field scale. In this area, it is indeed still a scientific and not an extension task to develop effective agricultural measures.

There is another important reason why feedback mechanisms are promising to better cope with water stress beyond the mere fact of being a more recent discovery compared to traditional measures. Recalling the distinction we initially introduced between dry climate and drought, we notice that most traditional measures target adaptation to a dry climate. The real challenge, however, is to cope with drought, i.e. the unpredictable deviation from normality. Using Levitt's terminology drought stress induces strain, i.e. a physical or chemical reaction of the stressed organism. Crop production requires a high degree of "elastic strain" within any of the manageable subsystems, i.e. soil and plant, to buffer potential damage, i.e. yield loss. Buffering is one of the main functions of soil. While soil buffers a lack of rainfall supply via storage capacity, plants - with a tightly bound storage capacity - respond to a shortage of soil supply by a complex hydraulic regulation system with isohydric vs. anisohydric behaviour as the extremes. We have to translate these mechanisms of resistance and resilience to extreme events from the natural ecosystem to the specificity of cropping systems: Crop scientists have to detect manageable and yield effective mechanisms from the pedological and physiological resistance and resilience to better withstand the uncertainty of drought.
Several empirical studies demonstrate that there is a huge loss of efficiency between water arrival at the field by rainfall or irrigation and uptake by the plant. Runoff, drainage, evaporation and unused water after harvest all seriously limit potential yield. In each of the processes in this chain of (in)efficiencies, the plant root is closely involved. Still, is an abysmal gap between the commonplace of the root being the organ of plant water supply and our capacity to manage the "hidden half". This has to do with something each plant breeder fears: genotype by environment interaction. The plant root is extremely variable with high epistasis, multiple gene control of traits and only few constitutive characters. Root systems cannot be understood without their interaction with the surrounding soil; their research and understanding is the domain par excellence for crop ecology. Both sides of root-soil interaction are relevant for crop production: soil conditioning by roots, and root conditioning by soil. Existing results suggest that there is a margin for targeted soil management by making use of root system diversity. On the other hand, soil as a given growth environment for roots largely influences the root system phenotype. For cropping system management, it is imperative to understand site hydrology to derive a suitable root system ideotype. Similar to aboveground genotype by environment interaction, adequate models could be used to better understand root trait by soil hydrology interactions and define adequate selection or management strategies.

While resistance and resilience against external forcing provide a useful advantage against unfavourable environmental events such as drought, it potentially limits the impact of management interventions. Several studies demonstrated the transient nature of management induced changes and a certain trend towards equilibration. The question therefore arises if plant-soil feedback mechanisms indeed provide a sufficiently effective way to improved productivity in a seemingly conservative system. This implicitly requires to address the question of variability: having discovered a promising process such as, for example, the capacity of roots to optimise rhizosphere water relations, the essential question for an applied science is if we are just in front of an exciting new scientific discovery of something that plants have optimised, or if there is variability of this process/property due to management, e.g. conventional vs. no tillage, or genotype which could be exploited. Revealing a new fact is just the first step in a long road that might finish in disappointment; well-known examples are some transgenic plants with superior stress resistance that ended at the door of the lab.

Still, from an ecological point of view there are reasons for optimism: As soon as we look beyond the cropping system to other land use in the same environment, it is evident that environment is not the prime constraint for improvement. Several modelling studies confirm the substantial gap between potential site productivity and actual yields. Understanding the biological, physical and chemical potential of ecosystems, 
crop ecology can identify inherent and superable limits of cropping system productivity. Crop ecologists try to capture processes explaining the entire feedback loop: from innovative agronomic measures to enhanced soil fertility towards better yield as final target. This effort will certainly profit from new measurement methods that allow further insight into the ecological functioning of the plant-soil system. Our efforts for better measurement and scientific understanding of processes however should not forget the need for field observation of diversity in agro-ecosystems: There are innumerable management "experiments" from open minded farmers that equally open minded crop scientists could make use of to discover improved practices that invite for a scientific explanation. Both directions, from scientific discovery to management as well as from management to scientific discovery, offer promising and exciting prospects.

\section{References}

Adisarwanto T, Knight R (1997) Effect of sowing date and plant density on yield and yield components in the faba bean. Aust J Agric Res 48: 1161-1168. doi:10.1071/A96050

Agam N, Berliner PR (2006) Dew formation and water vapor adsorption in semi-arid environments - a review. J Arid Environ 65:572-590. doi:10.1016/j.jaridenv.2005.09.004

Aisawi KAB (2012) Physiological processes associated with genetic progress in yield potential of wheat (Triticum aestivum L.). Dissertation, University of Nottingham

Akbarian A, Arzani A, Salehi M, Salehi M (2011) Evaluation of triticale genotypes for terminal drought tolerance using physiological traits. Indian J Agr Sci 81:1110-1115

Ali ML, Rajewski JF, Baenziger PS, Gill KS, Eskridge KM, Dweikat I (2008) Assessment of genetic diversity and relationship among a collection of US sweet sorghum germplasm by SSR markers. Mol Breed 21:497-509. doi:10.1007/s11032-007-9149-z

Allen MF (2007) Mycorrhizal fungi: highways for water and nutrients in arid soils. Vadose Zone J 6:291-297. doi:10.2136/vzj2006.0068

Allen RG, Pereira LS, Raes D, Smith M (1998) Crop evapotranspiration. Guidelines for computing crop water requirements. FAO Irrigation and drainage paper 56. FAO, Rome

Allen SJ (1990) Measurement and estimation of evaporation from soil under sparse barley crops in northern Syria. Agr Forest Meteorol 49: 291-309. doi:10.1016/0168-1923(90)90003-O

Álvaro F, Isidro J, Villegas D, García del Moral LF, Royo C (2008) Breeding effects on grain filling, biomass partitioning, and remobilization in Mediterranean durum wheat. Agron J 100:361-370. doi: 10.2134/agronj2007.0075

Anderson SH (2011) Cropping systems, effect on soil physical properties. Encyclopedia of Agrophysics, 180

Angers DA, Caron J (1998) Plant-induced changes in soil structure: Processes and feedbacks. In: Van Breemen N (ed) Plant-induced soil changes: processes and feedbacks. Springer, The Netherlands, pp $55-72$

Aparicio N, Villegas D, Casadesus J, Araus JL, Royo C (2000) Spectral vegetation indices as nondestructive tools for determining durum wheat yield. Agron J 92:83-91. doi:10.2134/agronj2000.92183x
Araus JL, Cairns JE (2014) Field high-throughput phenotyping: the new crop breeding frontier. Trends Plant Sci 19:52-61. doi:10.1016/j. tplants.2013.09.008

Araus JL, Slafer GA, Reynolds MP, Royo C (2002) Plant breeding and drought in $\mathrm{C}_{3}$ cereals: what should we breed for? Ann Bot 89:925940. doi:10.1093/aob/mcf049

Araus JL, Slafer GA, Royo C, Serret MD (2008) Breeding for yield potential and stress adaptation in cereals. Crit Rev Plant Sci 27: 377-412. doi:10.1080/07352680802467736

Arduini I, Masoni A, Ercoli L, Mariotti M (2006) Grain yield, and dry matter and nitrogen accumulation and remobilization in durum wheat as affected by variety and seeding rate. Eur J Agron 25: 309-318. doi:10.1016/j.eja.2006.06.009

Armstrong RD, Kuskopf BJ, Millar G, Whitbread AM, Standley J (1999) Changes in soil chemical and physical properties following legumes and opportunity cropping on a cracking clay soil. Anim Prod Sci 39: 445-456. doi:10.1071/EA99014

Aroca R, Ruiz-Lozano JM (2012) Regulation of root water uptake under drought stress conditions. In: Aroca R (ed) Plant responses to drought stress. Springer, Berlin Heidelberg, pp 113-127

Asbjornsen H, Goldsmith GR, Alvarado-Barrientos MS, Rebel K, Van Osch FP, Rietkerk M, Chen J, Gotsch S, Tobón C, Geissert DR, Gómez-Tagle A, Vache K, Dawson TE (2011) Ecohydrological advances and applications in plant-water relations research: a review. $\mathrm{J}$ Plant Ecol 4:3-22. doi:10.1093/jpe/rtr005

Aspinall D, Nicholls PB, May LH (1964) The effects of soil moisture stress on the growth of barley. I: vegetative development and grain yield. Crop Pasture Sci 15:729-745

Asseng S, Fillery IRP, Dunin FX, Keating BA, Meinke H (2000) Potential deep drainage under wheat crops in a Mediterranean climate. I: temporal and spatial variability. Crop Pasture Sci 52:45-56. doi:10.1071/AR99187

Athmann M, Kautz T, Pude R, Köpke U (2013) Root growth in biopores - evaluation with in situ endoscopy. Plant Soil 371:179190. doi:10.1007/s11104-013-1673-5

Azooz RH, Arshad MA, Franzluebbers AJ (1996) Pore size distribution and hydraulic conductivity affected by tillage in northwestern Canada. Soil Sci Soc Am J 60:1197-1201. doi:10.2136/sssaj1996. 03615995006000040034x

Babu RC, Pathan MS, Blum A, Nguyen HT (1999) Comparison of measurement methods of osmotic adjustment in rice cultivars. Crop Sci 39:150-158. doi:10.2135/cropsci1999.0011183X003900010024x

Bajji M, Kinet JM, Lutts S (2002) The use of the electrolyte leakage method for assessing cell membrane stability as a water stress tolerance test in durum wheat. Plant Growth Regul 36:61-70. doi:10. 1023/A:1014732714549

Baldocchi DD, Verma SB, Rosenberg NJ, Blad BL, Specht JE (1985) Microclimate-plant architectural interactions: influence of leaf width on the mass and energy exchange of a soybean canopy. Agr Forest Meteorol 35:1-20. doi:10.1016/0168-1923(85)90070-X

Ballaré CL, Caldwell MM, Flint SD, Robinson SA, Bornman JF (2011) Effects of solar ultraviolet radiation on terrestrial ecosystems. Patterns, mechanisms, and interactions with climate change. J Photochem Photobiol Sci 10:226-241. doi:10.1039/C0PP90035D

Barbieri P, Echarte L, Della Maggiora A, Sadras VO, Echeverria H, Andrade FH (2012) Maize evapotranspiration and water-use efficiency in response to row spacing. Agron J 104:939-944. doi:10. 2134/agronj2012.0014

Barraclough PB, Leigh RA (1984) The growth and activity of winter wheat roots in the field: the effect of sowing date and soil type on root growth of high-yielding crops. J Agri Sci 103:59-74

Bartens J, Day SD, Harris JR, Dove JE, Wynn TM (2008) Can urban tree roots improve infiltration through compacted subsoils for stormwater management? J Environ Qual 37:2048-2057. doi:10. 2134/jeq2008.0117 
Barthes B, Roose E (2002) Aggregate stability as an indicator of soil susceptibility to runoff and erosion: validation at several levels. Catena 47:133-149. doi:10.1016/S0341-8162(01)00180-1

Bayala J, Sileshi GW, Coe R, Kalinganire A, Tchoundjeu Z, Sinclair F, Garrity D (2012) Cereal yield response to conservation agriculture practices in drylands of West Africa: a quantitative synthesis. J Arid Environ 78:13-25. doi:10.1016/j.jaridenv.2011.10.011

Benbi DK, Biswas CR, Bawa SS, Kumar K (1998) Influence of farmyard manure, inorganic fertilizers and weed control practices on some soil physical properties in a long-term experiment. Soil Use Manag 14: 52-54. doi:10.1111/j.1475-2743.1998.tb00610.x

Bengough AG, McKenzie BM, Hallett PD, Valentine TA (2011) Root elongation, water stress, and mechanical impedance: a review of limiting stresses and beneficial root tip traits. J Exp Bot 62:59-68. doi: $10.1093 / \mathrm{jxb} / \mathrm{erq} 350$

Bennie ATP, Hensley M (2001) Maximizing precipitation utilization in dryland agriculture in South Africa - a review. J Hydrol 241:124 139. doi:10.1016/S0022-1694(00)00377-2

Berzsenyi Z, Dang QL (2008) Effect of sowing date and N fertilisation on the yield and yield stability of maize (Zea mays L.) hybrids in a longterm experiment. Acta Agron Hung 56:247-264. doi:10.1556/ AAgr.56.2008.3.1

Berzsenyi Z, Lap DQ (2005) Responses of maize (Zea mays L.) hybrids to sowing date, $\mathrm{N}$ fertiliser and plant density in different years. Acta Agron Hung 53:119-131. doi:10.1556/AAgr.53.2005.2.1

Bescansa P, Imaz MJ, Virto I, Enrique A, Hoogmoed WB (2006) Soil water retention as affected by tillage and residue management in semiarid Spain. Soil Till Res 87:19-27. doi:10.1016/j.still.2005.02. 028

Bhattacharyya R, Chandra S, Singh RD, Kundu S, Srivastva AK, Gupta HS (2007) Long-term farmyard manure application effects on properties of a silty clay loam soil under irrigated wheat-soybean rotation. Soil Till Res 94:386-396. doi:10.1016/j.still.2006.08.014

Bhattacharyya R, Prakash V, Kundu S, Gupta HS (2006) Effect of tillage and crop rotations on pore size distribution and soil hydraulic conductivity in sandy clay loam soil of the Indian Himalayas. Soil Till Res 86:129-140. doi:10.1016/j.still.2005.02.018

Blair N, Faulkner RD, Till AR, Crocker GJ (2006a) Long-term management impacts on soil C, $\mathrm{N}$ and physical fertility. Part III: Tamworth crop rotation experiment. Soil Till Res 91:48-56. doi:10.1016/j.still. 2005.11.003

Blair N, Faulkner RD, Till AR, Korschens M, Schulz E (2006b) Longterm management impacts on soil C, $\mathrm{N}$ and physical fertility: part II: bad Lauchstadt static and extreme FYM experiments. Soil Till Res 91:39-47. doi:10.1016/j.still.2005.11.001

Blair N, Faulkner RD, Till AR, Poulton PR (2006c) Long-term management impacts on soil $\mathrm{C}, \mathrm{N}$ and physical fertility. Part I: broadbalk experiment. Soil Till Res 91:30-38. doi:10.1016/j.still.2005.11.002

Blum A (1998) Improving wheat grain filling under stress by stem reserve mobilisation. Euphytica 100:77-83. doi:10.1023/ A: 1018303922482

Blum A (2005) Drought resistance, water-use efficiency, and yield potential - are they compatible, dissonant, or mutually exclusive? Aust J Agr Res 56:1159-1168. doi:10.1071/AR05069

Blum A (2009) Effective use of water (EUW) and not water-use efficiency (WUE) is the target of crop yield improvement under drought stress. Field Crops Res 112:119-123. doi:10.1016/j.fcr.2009.03.009

Blum A (2011) Plant breeding for water-limited environments. Springer, New York

Blum A, Ebercon A (1981) Cell membrane stability as a measure of drought and heat tolerance in wheat. Crop Sci 21:43-47. doi:10. 2135/cropsci1981.0011183X002100010013x

Blum A, Mayer J, Gozlan G (1982) Infrared thermal sensing of plant canopies as a screening technique for dehydration avoidance in wheat. Field Crops Res 5:137-146. doi:10.1016/0378-4290(82) 90014-4
Bodner G, Scholl P, Loiskandl W, Kaul HP (2013) Environmental and management influences on temporal variability of near saturated soil hydraulic properties. Geoderma 204:120-129. doi:10.1016/j. geoderma.2013.04.015

Bodner G, Leitner D, Kaul HP (2014). Coarse and fine root plants affect pore size distributions differently. Plant Soil 380:133-151. doi:10. 1007/s11104-014-2079-8

Bodner G, Loiskandl W, Buchan G, Kaul HP (2008) Natural and management-induced dynamics of hydraulic conductivity along a cover-cropped field slope. Geoderma 146:317-325. doi:10.1016/j. geoderma.2008.06.012

Bodner G, Loiskandl W, Kaul HP (2007) Cover crop evapotranspiration under semi-arid conditions using FAO dual crop coefficient method with water stress compensation. Agr Water Manag 93:85-98. doi: 10.1016/j.agwat.2007.06.010

Bodner G, Meier K, Wohlmuth ML, Kaul HP (2010) Analysis of cover crop effects on soil water dynamics using the simulation model DAISY. In: ALVA (eds.), Proceedings of the Annual Meeting, ISSN 1606-612X, 32-34 (In German, Abstract and figure captions in English)

Boese L (2010) Weizen zuerst säen. dlz-agrar-Magazin, August 2010, $38-42$

Bolaños J, Edmeades GO (1993) Eight cycles of selection for drought tolerance in lowland tropical maize. II: responses in reproductive behavior. Field Crops Res 31:253-268. doi:10.1016/03784290(93)90064-T

Bolaños J, Edmeades GO (1996) The importance of the anthesis-silking interval in breeding for drought tolerance in tropical maize. Field Crops Res 48:65-80. doi:10.1016/0378-4290(96)00036-6

Bronick CJ, Lal R (2005) Soil structure and management: a review. Geoderma 124:3-22. doi:10.1016/j.geoderma.2004.03.005

Brown LK, George TS, Thompson JA, Wright G, Lyon J, Dupuy L, Hubbard SF, White PJ (2012) What are the implications of variation in root hair length on tolerance to phosphorus deficiency in combination with water stress in barley (Hordeum vulgare)? Ann Bot 110: 319-328. doi:10.1093/aob/mes085

Brown RH (1999) Agronomic implications of $\mathrm{C}_{4}$ photosynthesis. In: Sage RF, Monson RK (eds) $\mathrm{C}_{4}$ Plant biology. A volume in physiological ecology. Academic, New York, pp 473-507

Brown SC, Gregory PJ, Cooper PJM, Keatinge JDH (1989) Root and shoot growth and water use of chickpea (Cicer arietinum) grown in dryland conditions: effects of sowing date and genotype. J Agric Sci 113:41-49

Buah SSJ, Mwinkaara S (2009) Response of sorghum to nitrogen fertilizer and plant density in the Guinea Savanna Zone. J Agron 8:124 130. doi:10.3923/ja.2009.124.130

Campos H, Cooper M, Edmeades GO, Loffler C, Schussler JR, Ibanez M (2006) Changes in drought tolerance in maize associated with fifty years of breeding for yield in the US corn belt. Maydica 51:369-381

Campos H, Cooper M, Habben JE, Edmeades GO, Schussler JR (2004) Improving drought tolerance in maize: a view from industry. Field Crops Res 90:19-34. doi:10.1016/j.fcr.2004.07.003

Capowiez Y, Cadoux S, Bouchant P, Ruy S, Roger-Estrade J, Richard G, Boizard H (2009) The effect of tillage type and cropping system on earthworm communities, macroporosity and water infiltration. Soil Till Res 105:209-216. doi:10.1016/j.still.2009.09.002

Carminati A, Moradi AB, Vetterlein D, Vontobel P, Lehmann E, Weller U, Vogel HJ, Oswald SE (2010) Dynamics of soil water content in the rhizosphere. Plant Soil 332:163-176. doi:10.1007/s11104-0100283-8

Carminati A, Schneider CL, Moradi AB, Zarebanadkouki M, Vetterlein D, Vogel HJ, Hildebrandt A, Wellerm U, Schüler L, Oswald SE (2011) How the rhizosphere may favor water availability to roots. Vadose Zone J 10:988-998. doi:10.2136/vzj2010.0113 
Carminati A, Vetterlein D (2012) Plasticity of rhizosphere hydraulic properties as a key for efficient utilization of scarce resources. Ann Bot 112:277-290. doi:10.1093/aob/mcs262

Carminati A, Vetterlein D, Weller U, Vogel HJ, Oswald SE (2009) When roots lose contact. Vadose Zone J 8:805-809. doi:10.2136/vzj2008. 0147

Carof M, De Tourdonnet S, Coquet Y, Hallaire V, Roger-Estrade J (2007) Hydraulic conductivity and porosity under conventional and no-tillage and the effect of three species of cover crop in northern France. Soil Use Manag 23:230-237. doi:10.1111/j. 1475-2743.2007.00085.x

Carter GA (1993) Responses of leaf spectral reflectance to plant stress. Am J Bot 80:239-243

Cattivelli L, Rizza F, Badeck FW, Mazzucotelli E, Mastrangelo AM, Francia E, Maré C, Tondelli A, Stanca AM (2008) Drought tolerance improvement in crop plants: an integrated view from breeding to genomics. Field Crops Res 105:1-14. doi:10.1016/j.fcr.2007.07. 004

Chaves MM, Maroco JP, Pereira JS (2003) Understanding plant responses to drought- from genes to the whole plant. Funct Plant Biol 30:239-264. doi:10.1071/FP02076

Chen C, Neill K, Wichman D, Westcott M (2008) Hard red spring wheat response to row spacing, seeding rate, and nitrogen. Agron J 100: 1296-1302. doi:10.2134/agronj2007.0198

Chen G, Weil RR (2010) Penetration of cover crop roots through compacted soils. Plant Soil 331:31-43. doi:10.1007/s11104-0090223-7

Chenkual V, Acharya CL (1990) Effect of rice-wheat and maize-wheat rotations on soil physical properties including soil water behaviour in an acidic Alfisol. J Indian Soc Soil Sci 38:574-582

Chenu K, Cooper M, Hammer GL, Mathews KL, Dreccer MF, Chapman SC (2011) Environment characterization as an aid to wheat improvement: interpreting genotype-environment interactions by modelling water-deficit patterns in North-Eastern Australia. J Exp Bot 62: 1743-1755. doi:10.1093/jxb/erq459

Chimenti CA, Pearson J, Hall AJ (2002) Osmotic adjustment and yield maintenance under drought in sunflower. Field Crops Res 75:235246. doi:10.1016/S0378-4290(02)00029-1

Choat B, Ball M, Luly J, Holtum J (2003) Pit membrane porosity and water stress-induced cavitation in four co-existing dry rainforest tree species. Plant Physiol 131:41-48. doi:10.1104/pp. 014100

Clark LJ, Barraclough PB (1999) Do dicotyledons generate greater maximum axial root growth pressures than monocotyledons? J Exp Bot 50:1263-1266

Clavel D, Drame NK, Roy-Macauley H, Braconnier S, Laffray D (2005) Analysis of early responses to drought associated with field drought adaptation in four Sahelian groundnut (Arachis hypogaea L.) cultivars. Environ Exp Bot 54:219-230. doi:10.1016/j.envexpbot.2004. 07.008

Cogle AL, Rao KPC, Yule DF, Smith GD, George PJ, Srinivasan ST, Jangawad L (2002) Soil management for Alfisols in the semiarid tropics: erosion, enrichment ratios and runoff. Soil Use Manag 18: 10-17. doi:10.1079/SUM2002094

Colin C, Siani G, Sicre MA, Liu Z (2010) Impact of the East Asian monsoon rainfall changes on the erosion of the Mekong River basin over the past 25,000 yr. Marine Geology 271:84-92. doi:10.1016/j. margeo.2010.01.013

Comstock JP (2002) Hydraulic and chemical signalling in the control of stomatal conductance and transpiration. J Exp Bot 53:195-200

Condon AG, Richards RA, Rebetzke GJ, Farquhar GD (2004) Breeding for high water-use efficiency. J Exp Bot 55:2447-2460. doi:10. 1093/jxb/erh277

Condon AG, Richards RA, Rebetzke GJ, Farquhar GD (2002) Improving intrinsic water-use efficiency and crop yield. Crop Sci 42:122-131. doi:10.2135/cropsci2002.1220
Connor DJ, Loomis RS, Cassman KG (2011) Crop ecology: productivity and management in agricultural systems, 2nd edn. Cambridge University Press, New York

Cosgrove DJ (1993) Wall extensibility: its nature, measurement and relationship to plant cell growth. New Phytol 124:1-23. doi:10.1111/j. 1469-8137.1993.tb03795.x

Cresswell HP, Kirkegaard JA (1995) Subsoil amelioration by plantroots - the process and the evidence. Soil Res 33:221-239. doi:10. 1071/SR9950221

Cutforth HW, McConkey BG, Woodvine RJ, Smith DG, Jefferson PG, Akinremi OO (1999) Climate change in the semiarid prairie of southwestern Saskatchewan: late winter-early spring. Can J Plant Sci 79:343-350. doi:10.4141/P98-137

Darboux F, Huang CH (2005) Does soil surface roughness increase or decrease water and particle transfers? Soil Sci Soc Am J 69:748756. doi:10.2136/sssaj2003.0311

Davies WJ, Zhang J (1991) Root signals and the regulation of growth and development of plants in drying soil. Ann Rev Plant Biol 42:55-76. doi:10.1146/annurev.pp. 42.060191.000415

De Gryze S, Six J, Merckx R (2006) Quantifying water-stable soil aggregate turnover and its implication for soil organic matter dynamics in a model study. Eur J Soil Sci 57:693-707. doi:10.1111/j.1365-2389. 2006.00760.x

De Rouw A (2004) Improving yields and reducing risks in pearl millet farming in the African Sahel. Agric Sys 81:73-93. doi:10.1016/j. agsy.2003.09.002Document

De Willigen P, Nielsen NE, Claassen N, Castrignanò AM (2000) Modelling water nutrient uptake. In: Smit AL, Bengough AG, Engels C, van Noordwijk M, Pellerin S, van de Geijn SC (eds) Root methods - a handbook. Springer, Berlin, pp 511-543

De Wit CT (1958) Transpiration and crop yields. Versl Landbouwk Onderz 64:6

Debaeke P, Aboudrare A (2004) Adaptation of crop management to water-limited environments. Europ J Agron 21:433-446. doi:10. 1016/j.eja.2004.07.006

Del Moral LF, Rharrabti Y, Villegas D, Royo C (2003) Evaluation of grain yield and its components in durum wheat under Mediterranean conditions. Agron J 95:266-274. doi:10.2134/ agronj2003.2660

Denčić S, Kastori R, Kobiljski B, Duggan B (2000) Evaluation of grain yield and its components in wheat cultivars and landraces under near optimal and drought conditions. Euphytica 113:43-52. doi:10.1023/ A: 1003997700865

Derpsch R (1998) Historical review of no-tillage cultivation of crops. In: Benites J, Chuma E, Fowler R, Kienzle J, Molapong K, Manu J, Nyagumbo I, Steiner K, van Veenhuizen R (eds) Proceedings of the international workshop: conservation tillage for sustainable agriculture. FAO, Rome, pp 205-218

Dexter AR (1988) Advances in characterization of soil structure. Soil Till Res 11:199-238. doi:10.1016/0167-1987(88)90002-5

Dexter AR, Czyż EA, Niedzwiecki J, Maćkowiak C (2001) Water retention and hydraulic conductivity of a loamy sand soil as influenced by crop rotation and fertilization. Arch Agron Soil Sci 46:123-133

Dodd IC (2013) Abscisic acid and stomatal closure: a hydraulic conductance conundrum? New Phytol 197:6-8. doi:10.1111/nph. 12052

Doussan C, Verbambre G, Pagè L (1998) Modelling of the hydraulic architecture of root systems: an integrated approach to water absorption - distribution of axial and radial conductances in maize. Ann Bot 81:225-232. doi:10.1006/anbo.1997.0541

Dracup JA, Lee KS, Paulson EG (1980) On the statistical characteristics of drought events. Water Resour Res 16:289-296. doi:10.1029/ WR016i002p00289

Duggan BL, Domitruk DR, Fowler DB (2000) Yield component variation in winter wheat grown under drought stress. Can J Plant Sci 80: 739-745. doi:10.4141/P00-006 
Duvick DN (2005) Genetic progress in yield of United States maize (Zea mays L.). Maydica 50:193-202

Dzotsi K, Agboh-Noameshie A, Struif Bontkes TS, Singh U, Dejean P, Struif Bontkes TE, Wopereis MCS (2003) Using DSSAT to derive optimum combinations of cultivar and sowing date for maize in Southern Togo. In: Struif Bontkes TS, Wopereis MCS (eds) Decision support tools for smallholder agriculture in Sub-Saharan Africa (a practical guide). International Center for Soil Fertility and Agricultural/ACP-EU Technical Centre for Agricultural and Rural, Wageningen, pp 100-113

Eapen D, Barroso ML, Ponce G, Campos ME, Cassab GI (2005) Hydrotropism: root growth responses to water. Trends Plant Sci 10:44-50. doi:10.1016/j.tplants.2004.11.004

Eastham J, Gregory PJ, Williamson DR, Watson GD (1999) The influence of early sowing of wheat and lupin crops on evapotranspiration and evaporation from the soil surface in a Mediterranean climate. Agr Water Manag 42:205-218. doi:10.1016/S0378-3774(99) 00036-0

Eberbach PL, Humphreys E, Kukal SS (2011) The effect of rice straw mulch on evapotranspiration, transpiration and soil evaporation of irrigated wheat in Punjab, India. Agr Water Manag 98:1847-1855. doi:10.1016/j.agwat.2011.07.002

Ehlers W, Goss M (2003) Water dynamics in plant production. CABI Publishing, Wallingford

Ehrenfeld JG, Ravit B, Elgersma K (2005) Feedback in the plant-soil system. Ann Rev Environ Res 30:75-115. doi:10.1146/annurev. energy.30.050504.144212

Ekanayake IJ, De Datta SK, Steponkus PL (1989) Spikelet sterility and flowering response of rice to water stress at anthesis. Ann Bot 63: 257-264

Elliott ET, Coleman DC (1988) Let the soil work for us. Ecol Bull 39:2332

Erenstein O (2002) Crop residue mulching in tropical and semi-tropical countries: an evaluation of residue availability and other technological implications. Soil Till Res 67:115-133. doi:10.1016/S01671987(02)00062-4

Facelli JM, Pickett ST (1991) Plant litter: its dynamics and effects on plant community structure. Bot Rev 57:1-32. doi:10.1007/ BF02858763

Fang Y, Xu BC, Turner NC, Li FM (2010) Grain yield, dry matter accumulation and remobilization, and root respiration in winter wheat as affected by seeding rate and root pruning. Eur J Agron 33:257-266. doi:10.1016/j.eja.2010.07.001

FAO (2000) Land resource potential and constraints at regional and country levels. World Soil Resources Report 90. Rome

FAO (2003) Review of world water resources by country. Water Reports 23, FAO, Rome

FAO (2004a) Carbon sequestration in dryland soils. World Soil Resources Report 102, Rome

FAO (2004b) AQUASTAT Web site www.fao.org/ag/aquastat

Farahani HJ, Peterson GA, Westfall DG (1998) Dryland cropping intensification: a fundamental solution to efficient use of precipitation. Adv Agron 64:225-265

Farooq M, Hussain M, Wahid A, Siddique KHM (2012) Drought stress in plants: an overview. In: Aroca R (ed) Plant responses to drought stress. From morphological to molecular features. Springer, Berlin Heidelberg, pp 1-33

Farooq M, Wahid A, Lee DJ, Ito O, Siddique KHM (2009a) Advances in drought resistance of rice. Crit Rev Plant Sci 28:199-217. doi:10. 1080/07352680902952173

Farooq M, Wahid A, Kobayashi N, Fujita D, Basra SMA (2009b) Plant drought stress: effects, mechanisms and management. Agron Sustain Dev 29:185-212. doi:10.1051/agro:2008021

Farquhar GD, Richards RA (1984) Isotopic composition of plant carbon correlates with water-use efficiency of wheat genotypes. Funct Plant Biol 11:539-552. doi:10.1071/PP9840539
Farré I, Faci JM (2006) Comparative response of maize (Zea mays L.) and sorghum (Sorghum bicolor L. Moench) to deficit irrigation in a Mediterranean environment. Agr Water Manag 83:135-143. doi: 10.1016/j.agwat.2005.11.001

Fernández-Ugalde O, Virto I, Bescansa P, Imaz MJ, Enrique A, Karlen DL (2009) No-tillage improvement of soil physical quality in calcareous, degradation-prone, semiarid soils. Soil Tillage Res 106:29 35. doi:10.1016/j.still.2009.09.012

Ferreras LA, Costa JL, Garcia FO, Pecorari C (2000) Effect of no-tillage on some soil physical properties of a structural degraded Petrocalcic Paleudoll of the southern "Pampa" of Argentina. Soil Till Res 54: 31-39. doi:10.1016/S0167-1987(99)00102-6

Filella I, Serrano L, Serra J, Penuelas J (1995) Evaluating wheat nitrogen status with canopy reflectance indices and discriminant analysis. Crop Sci 35:1400-1405. doi:10.2135/cropsci1995. 0011183X003500050023x

Fischer RA, Sayre KD, Reynolds MP (2005) Osmotic adjustment in wheat in relation to grain yield under water deficit environments. Agron J 97:1062-1071. doi:10.2134/agronj2004.0152

Fitter AH (1987) An architectural approach to the comparative ecology of plant root systems. New Phytol 106:61-77

Flexas J, Medrano H (2002) Drought-inhibition of photosynthesis in $\mathrm{C}_{3}$ plants: stomatal and non-stomatal limitations revisited. Ann Bot 89: 183-189. doi:10.1093/aob/mcf027

Francia E, Tondelli A, Rizza F, Badeck FW, Li Destri Nicosia O, Akar T, Grando S, Al-Yassin A, Benbelkacem A, Thomas WTB, van Eeuwijk F, Romagosa I, Stanca AM, Pecchioni N (2011) Determinants of barley grain yield in a wide range of Mediterranean environments. Field Crops Res 120:169-178. doi: 10.1016/j.fcr.2010.09.010

Francis GS, Kemp RA (1990) Morphological and hydraulic properties of a silt loam soil in New Zealand as affected by cropping history. Soil Use Manag 6:145-151. doi:10.1111/j. 1475-2743.1990.tb00824.x

Fukai S, Sittisuang P, Chanphengsay M (1998) Increasing production of rainfed lowland rice in drought prone environments: a case study in Thailand and Laos. Plant Prod Sci 1:75-82. doi:10.1626/pps.1.75

Gajić B (2013) Physical properties and organic matter of Fluvisols under forest, grassland, and 100 years of conventional tillage. Geoderma 200:114-119. doi:10.1016/j.geoderma.2013.01.018

Gan Y, Angadi SV, Cutforth H, Potts D, Angadi VV, McDonald CL (2004) Canola and mustard response to short periods of temperature and water stress at different developmental stages. Can J Plant Sci 84:697-704. doi:10.4141/P03-109

Gardner WR (1960) Dynamic aspects of water availability to plants. Soil Sci 89:63-73

Gaur PM, Krishnamurthy L, Kashiwagi J (2008) Improving droughtavoidance root traits in chickpea (Cicer arietinum L.) - current status of research at ICRISAT. Plant Prod Sci 11:3-11. doi:10.1626/ pps. 11.3

Gilbert N (2010) How to avert a global water crisis? Nature. doi:10.1038/ news. 2010.490

Gilbert ME, Zwieniecki MA, Holbrook NM (2011) Independent variation in photosynthetic capacity and stomatal conductance leads to differences in intrinsic water use efficiency in 11 soybean genotypes before and during mild drought. J Exp Bot 62:2875-2887. doi:10. 1093/jxb/erq461

Gitz DC III, Liu-Gitz L, Britz SJ, Sullivan JH (2005) Ultraviolet-B effects on stomatal density, water-use efficiency, and stable carbon isotope discrimination in four glasshouse-grown soybean (Glyicine max) cultivars. Environ Exp Bot 53:343-355. doi:10.1016/j.envexpbot. 2004.04.005

Głąb T, Ścigalska B, Łabuz B (2013) Effect of crop rotations with triticale (Triticosecale Wittm.) on soil pore characteristics. Geoderma 202:17. doi:10.1016/j.geoderma.2013.03.002 
Gómez JA, Romero P, Giráldez JV, Fereres E (2004) Experimental assessment of runoff and soil erosion in an olive grove on a Vertic soil in southern Spain as affected by soil management. Soil Use Manag 20:426-431. doi:10.1079/SUM2004275

Gomez-Macpherson H, Richards RA (1995) Effect of sowing time on yield and agronomic characteristics of wheat in south-eastern Australia. Aust J Agr Res 46:1381-1399. doi:10.1071/AR9951381

Gooding MJ, Ellis RH, Shewry PR, Schofield JD (2003) Effects of restricted water availability and increased temperature on the grain filling, drying and quality of winter wheat. J Cereal Sci 37:295309. doi:10.1006/jcrs.2002.0501

Gouache D, Le Bris X, Bogard M, Deudon O, Pagé C, Gate P (2012) Evaluating agronomic adaptation options to increasing heat stress under climate change during wheat grain filling in France. Eur J Agron 39:62-70. doi:10.1016/j.eja.2012.01.009

Graeff S, Claupein W (2003) Quantifying nitrogen status of corn (Zea mays L.) in the field by reflectance measurements. Eur J Agron 19: 611-618. doi:10.1016/S1161-0301(03)00007-8

Green TR, Ahuja LR, Benjamin JG (2003) Advances and challenges in predicting agricultural management effects on soil hydraulic properties. Geoderma 116:3-27. doi:10.1016/S0016-7061(03)00091-0

Gregory PJ (2004) Agronomic approaches to increasing water use efficiency. In: Bacon M (ed) Water use efficiency in plant biology. CRC Press, Boca Raton, pp 142-170

Gregory PJ (2006) Roots, rhizosphere and soil: the route to a better understanding of soil science? Eur J Soil Sci 57:2-12. doi:10.1111/j. 1365-2389.2005.00778.x

Gregory PJ, Bengough AG, George TS, Hallett PD (2013) Rhizosphere engineering by plants: quantifying soil-root interactions. In: Timlin D, Ahuja LR (eds) Enhancing understanding and quantification of soil-root growth interactions. advances in agricultural systems modeling, vol 4., pp 1-30

Gregory PJ, Simmonds LP, Pilbeam CJ (2000) Soil type, climatic regime, and the response of water use efficiency to crop management. Agron J 92:814-820. doi:10.2134/agronj2000.925814x

Gresset S, Westermeier P, Rademacher S, Ouzunova M, Presterl T, Westhoff P, Schön CC (2014) Stable carbon isotope discrimination is under genetic control in the $\mathrm{C}_{4}$ species maize with several genomic regions influencing trait expression. Plant Physiol 164:131143. doi:10.1104/pp. 113.224816

Guswa AJ (2010) Effect of plant-uptake strategy on the water-optimal root depth. Water Resour Res 46:W09601. doi:10.1029/ 2010WR009122

Gutierrez M, Reynolds MP, Klatt AR (2010) Association of water spectral indices with plant and soil water relations in contrasting wheat genotypes. J Exp Bot 61:3291-3303. doi:10.1093/jxb/erq156

Gyssels G, Poesen J, Bochet E, Li Y (2005) Impact of plant roots on the resistance of soils to erosion by water: a review. Prog Phys Geog 29: 189-217. doi:10.1191/0309133305pp443ra

Hamblin AP, Tennant D (1987) Root length density and water uptake in cereals and grain legumes: how well are they correlated. Aust J Agr Res 38:513-527. doi:10.1071/AR9870513

Hammer GL, Dong Z, McLean G, Doherty A, Messina C, Schussler J, Zinselmeier C, Paszkiewicz S, Cooper M (2009) Can changes in canopy and/or root system architecture explain historical maize yield trends in the US corn belt? Crop Sci 49:299-312. doi:10. 2135/cropsci2008.03.0152

Hangen E, Buczko U, Bens O, Brunotte J, Hüttl RF (2002) Infiltration patterns into two soils under conventional and conservation tillage: influence of the spatial distribution of plant root structures and soil animal activity. Soil Till Res 63:181-186. doi:10.1016/S01671987(01)00234-3

Hatfield KL, Pruegar JH (1996) Microclimate effects of crop residues on biological processes. Theor Appl Climatol 54:47-59. doi:10.1007/ BF00863558
Hathaway-Jenkins LJ, Sakrabani R, Pearce B, Whitmore AP, Godwin RJ (2011) A comparison of soil and water properties in organic and conventional farming systems in England. Soil Use Manag 27: 133-142. doi:10.1111/j.1475-2743.2011.00335.x

Hay RKM (1995) Harvest index: a review of its use in plant breeding and crop physiology. Ann Appl Biol 126:197-216

Haynes RJ, Naidu R (1998) Influence of lime, fertilizer and manure applications on soil organic matter content and soil physical conditions: a review. Nutr Cycl Agroecosys 51:123-137. doi:10.1023/ A: 1009738307837

Henderson S, Von Caemmerer S, Farquhar GD, Wade L, Hammer G (1998) Correlation between carbon isotope discrimination and transpiration efficiency in lines of the $\mathrm{C}_{4}$ species Sorghum bicolor in the glasshouse and the field. Funct Plant Biol 25:111-123. doi:10.1071/ PP95033

Herrero MP, Johnson RR (1981) Drought stress and its effects on maize reproductive systems. Crop Sci 21:105-110

Hillel D (1980) Applications of soil physics. Academic, New York

Hirayama M, Wada Y, Nemoto H (2006) Estimation of drought tolerance based on leaf temperature in upland rice breeding. Breeding Sci 56: 47-54. doi:10.1270/jsbbs.56.47

Hodge A, Berta G, Doussan C, Merchan F, Crespi M (2009) Plant root growth, architecture and function. Plant Soil 321:153-187. doi:10. 1007/s11104-009-9929-9

Hoekstra AY, Mekonnen MM (2012) The water footprint of humanity. PNAS 109:3232-3237. doi:10.1073/pnas.1109936109

Hsiao TC (1973) Plant responses to water stress. Ann Rev Plant Physiol 24:519-570

Hsiao TC, Steduto P, Fereres E (2007) A systematic and quantitative approach to improve water use efficiency in agriculture. Irrigation Sci 25:209-231. doi:10.1007/s00271-007-0063-2

Hsiao TC, Xu LK (2000) Sensitivity of growth of roots versus leaves to water stress: biophysical analysis and relation to water transport. J Exp Bot 51:1595-1616. doi:10.1093/jexbot/51.350.1595

Huang B, Fry JD (1998) Root anatomical, physiological, and morphological responses to drought stress for tall fescue cultivars. Crop Sci 38:1017-1022. doi:10.2135/cropsci1998. 0011183X003800040022x

Huda AKS (1988) Simulating growth and yield responses of sorghum to changes in plant density. Agron J 80:541-547

Hudson BD (1994) Soil organic matter and available water capacity. J Soil Water Conserv 49:189-194

Humphreys E, Meisner C, Gupta R, Timsina J, Beecher HG, Lu TY, Singh Y, Gill MA, Masih I, Guo ZJ, Thompson JA (2005) Water saving in rice-wheat systems. Plant Prod Sci 8:242-258. doi:10. 1626/pps.8.242

Hund A, Ruta N, Liedgens M (2009a) Rooting depth and water use efficiency of tropical maize inbred lines, differing in drought tolerance. Plant Soil 318:311-325. doi:10.1007/s11104-008-9843-6

Hund A, Trachsel S, Stamp P (2009b) Growth of axile and lateral roots of maize. I: development of a phenotyping platform. Plant Soil 325: 335-349. doi:10.1007/s11104-009-9984-2

Incerti M, O'Leary GJ (1990) Rooting depth of wheat in the Victorian Mallee. Aus J Exp Agr 30:817-824

Isidro J, Álvaro F, Royo C, Villegas D, Miralles DJ, del Moral LFG (2011) Changes in duration of developmental phases of durum wheat caused by breeding in Spain and Italy during the 20th century and its impact on yield. Ann Bot 107:1355-1366. doi:10.1093/aob/ mor063

Islam N, Wallender WW, Mitchell J, Wicks S, Howitt RE (2006) A comprehensive experimental study with mathematical modelling to investigate the effects of cropping practices on water balance variables. Agr Water Manag 82:129-147. doi:10.1016/j.agwat. 2005.07.029 
Jalota SK, Arora VK (2002) Model-based assessment of water balance components under different cropping systems in north-west India. Agr Water Manag 57:75-87. doi:10.1016/S0378-3774(02)00049-5

Jeuffroy MH, Casadebaig P, Debaeke P, Loyce C, Meynard JM (2014) Agronomic model uses to predict cultivar performance in various environments and cropping systems. A review. Agron Sustain Dev 34:121-137. doi:10.1007/s13593-013-0170-9

Jones HG (2009) What is water use efficiency? In: Bacon M (ed) Water use efficiency in plant biology. CRC Press, pp 27-41

Jones HG (1992) Plants and microclimate: a quantitative approach to environmental plant physiology. Cambridge University Press

Jones HG, Flowers TJ, Jones MB (2008) Plants under stress: biochemistry, physiology and ecology and their application to plant improvement. Cambridge University Press, Cambridge

Jones HG, Stoll M, Santos T, De Sousa C, Chaves MM, Grant OM (2002) Use of infrared thermography for monitoring stomatal closure in the field: application to grapevine. J Exp Bot 53:2249-2260. doi:10. 1093/jxb/erf083

Jones MJ, Singh M (2000) Long-term yield patterns in barley-based cropping systems in northern Syria. 1. comparison of rotations. J Agr Sci 135:223-236

Jongdee B, Fukai S, Cooper M (2002) Leaf water potential and osmotic adjustment as physiological traits to improve drought tolerance in rice. Field Crops Res 76:153-163. doi:10.1016/S0378-4290(02) 00036-9

Kadioglu A, Terzi R, Saruhan N, Saglam A (2012) Current advances in the investigation of leaf rolling caused by biotic and abiotic stress factors. Plant Sci 182:42-48. doi:10.1016/j.plantsci.2011.01.013

Kálmar T, Bottlik L, Kisić I, Gyuricza C, Birkás M (2013) Soil protecting effect of the surface cover in extreme summer periods. Plant Soil Environ 59:404-409

Karcher DE, Richardson MD, Hignight K, Rush D (2008) Drought tolerance of tall fescue populations selected for high root/shoot ratios and summer survival. Crop Sci 48:771-777. doi:10.2135/ cropsci2007.05.0272

Kashiwagi J, Krishnamurthy L, Crouch JH, Serraj R (2006) Variability of root length density and its contributions to seed yield in chickpea (Cicer arietinum L.) under terminal drought stress. Field Crops Res 95:171-181. doi:10.1016/j.fcr.2005.02.012

Kashiwagi J, Krishnamurthy L, Upadhyaya HD, Krishna H, Chandra S, Vadez V, Serraj R (2005) Genetic variability of drought-avoidance root traits in the mini-core germplasm collection of chickpea (Cicer arietinum L.). Euphytica 146:213-222. doi:10.1007/s10681-0059007-1

Kato Y, Abe J, Kamoshita A, Yamagishi J (2006) Genotypic variation in root growth angle in rice (Oryza sativa L.) and its association with deep root development in upland fields with different water regimes. Plant Soil 287:117-129. doi:10.1007/s11104-006-9008-4

Kay BD (1990) Rates of change of soil structure under different cropping systems. Adv Soil Sci 12:1-52. doi:10.1007/978-1-4612-3316-9 1

Kay BD, VandenBygaart AJ (2002) Conservation tillage and depth stratification of porosity and soil organic matter. Soil Till Res 66:107118. doi:10.1016/S0167-1987(02)00019-3

Kell DB (2011) Breeding crop plants with deep roots: their role in sustainable carbon, nutrient and water sequestration. Ann Bot 108:407418. doi:10.1093/aob/mcr175

Kholová J, Hash CT, Kakkera A, Kočová M, Vadez V (2010) Constitutive water-conserving mechanisms are correlated with the terminal drought tolerance of pearl millet [Pennisetum glaucum $(\mathrm{L}$.) R. Br.]. J Exp Bot 61:369-377. doi:10.1093/jxb/erp314

Kirkegaard JA, Lilley JM, Howe GN, Graham JM (2007) Impact of subsoil water use on wheat yield. Aust J Agr Res 58:303-315. doi:10.1071/AR06285

Kirkham MB (2005) Principles of soil and plant water relations. Academic, Burlington
Kirkland KJ, Johnson EN (2000) Alternative seeding dates (fall and April) affect Brassica napus canola yield and quality. Can J Plant Sci 80:713-719. doi:10.4141/P00-016

Kleemann SGL, Gill GS (2010) Influence of row spacing on water use and yield of rain-fed wheat (Triticum aestivum L.) in a no-till system with stubble retention. Aust J Agr Res 61:892-898. doi:10.1071/ CP10124

Klik A, Eitzinger J (2010) Impact of climate change on soil erosion and the efficiency of soil conservation practices in Austria. J Agr Sci 148:529-541. doi:10.1017/S0021859610000158

Kodešová R, Jirků V, Kodeš V, Mühlhanselová M, Nikodem A, Žigová A (2011) Soil structure and soil hydraulic properties of HaplicLuvisol used as arable land and grassland. Soil Till Res 111:154-161. doi: 10.1016/j.still.2010.09.007

Kohler-Milleret R, Le Bayon RC, Chenu C, Gobat JM, Boivin P (2013) Impact of two root systems, earthworms and mycorrhizae on the physical properties of an unstable silt loam Luvisol and plant production. Plant Soil 370:251-265. doi:10.1007/s11104-013-1621-4

Konrad W, Burkhardt J, Ebner M, Roth-Nebelsick A (2014) Leaf pubescence as a possibility to increase water use efficiency by promoting condensation. Ecohydrol. doi:10.1002/eco.1518

Kramer PJ, Boyer JS (1995) Water relations of plants and soils. Academic, San Diego

Kumar S, Kadono A, Lal R, Dick W (2012) Long-term tillage and crop rotations for 47-49 years influences hydrological properties of two soils in Ohio. Soil Sci Soc Am J 76:2195-2207. doi:10.2136/ sssaj2012.0098

Łabędzki L (2007) Estimation of local drought frequency in central Poland using the standardized precipitation index SPI. Irrig Drain 56:67-77. doi:10.1002/ird.285

Lado M, Ben-Hur M, Shainberg I (2004) Soil wetting and texture effects on aggregate stability, seal formation, and erosion. Soil Sci Soc Am J 68:1992-1999. doi:10.2136/sssaj2004.1992

Lampurlanés J, Cantero-Martínez C (2006) Hydraulic conductivity, residue cover and soil surface roughness under different tillage systems in semiarid conditions. Soil Till Res 85:13-26. doi:10.1016/j.still. 2004.11.006

Larcher W (1994) Ökophysiologie der Pflanzen. Ulmer Verlag, Stuttgart

Latiri K, Lhomme JP, Annabi M, Setter TL (2010) Wheat production in Tunisia: progress, inter-annual variability and relation to rainfall. Eur J Agron 33:33-42. doi:10.1016/j.eja.2010.02.004

Lauriano JA, Lidon FC, Carvalho CA, Campos PS, Do Ceu Matos M (2000) Drought effects on membrane lipids and photosynthetic activity in different peanut cultivars. Photosynthetica 38:7-12. doi:10. 1023/A:1026775319916

Lavalle C, Micale F, Houston TD, Camia A, Hiederer R, Lazar C, Conte C, Amatulli G, Genovese G (2009) Climate change in Europe. 3: impact on agriculture and forestry. A review. Agron Sustain Dev 29: 433-446. doi:10.1051/agro/2008068

Lavelle P, Decaëns T, Aubert M, Barot S, Blouin M, Bureau F, Margerie P, Mora P, Rossi JP (2006) Soil invertebrates and ecosystem services. Eur J Soil Biol 42:S3-S15. doi:10.1016/j.ejsobi.2006.10.002

Lavot H, Maurel C (2002) The role of aquaporins in root water uptake. Ann Bot 90:301-313

Leegood RC (2002) $\mathrm{C}_{4}$ photosynthesis: principles of $\mathrm{CO}_{2}$ concentration and prospects for its introduction into $\mathrm{C}_{3}$ plants. $\mathrm{J}$ Exp Bot 53:581590. doi:10.1093/jexbot $/ 53.369 .581$

Lehner B, Döll P, Alcamo J, Henrichs T, Kaspar F (2006) Estimating the impact of global change on flood and drought risks in Europe: a continental, integrated analysis. Clim Chang 75:273-299. doi:10. 1007/s10584-006-6338-4

Leij FJ, Ghezzehei TA, Or D (2002) Modeling the dynamics of the soil pore-size distribution. Soil Till Res 64:61-78. doi:10.1016/S01671987(01)00257-4 
Leitner D, Klepsch S, Bodner G, Schnepf A (2010) A dynamic root system growth model based on L-systems. Plant Soil 332:177192. doi:10.1007/s11104-010-0284-7

Lesturgez G, Poss R, Hartmann C, Bourdon E, Noble A, Ratana-Anupap S (2004) Roots of Stylosanthes hamata create macropores in the compact layer of a sandy soil. Plant Soil 260:101-109. doi:10. 1023/B:PLSO.0000030184.24866.aa

Levitt J (1980) Responses of plants to environmental stresses. Physiological ecology series. Academic, Michigan

Link W, Hocking TJ, Stoddard FL (2007) Evaluation of physiological traits for improving drought tolerance in faba bean (Vicia faba L.). Plant Soil 292:205-217. doi:10.1007/s11104-007-9217-5

Lipiec J, Kuś J, Słowińska-Jurkiewicz A, Nosalewicz A (2006) Soil porosity and water infiltration as influenced by tillage methods. Soil Till Res 89:210-220. doi:10.1016/j.still.2005.07.012

Lisanti S, Hall AJ, Chimenti CA (2013) Influence of water deficit and canopy senescence pattern on Helianthus annuus (L.) root functionality during the grain-filling phase. Field Crops Res 154:1-11. doi: 10.1016/j.fcr.2013.08.009

Liu A, Ma BL, Bomke AA (2005) Effects of cover crops on soil aggregate stability, total organic carbon, and polysaccharides. Soil Sci Soc Am J 69:2041-2048. doi:10.2136/sssaj2005.0032

Liu C, Zhang X, Zhang Y (2002) Determination of daily evaporation and evapotranspiration of winter wheat and maize by large-scale weighing lysimeter and micro-lysimeter. Agr Forest Meteorol 111: 109-120. doi:10.1016/S0168-1923(02)00015-1

Liu Y, Subhash C, Yan J, Song C, Zhao J, Li J (2011) Maize leaf temperature responses to drought: thermal imaging and quantitative trait loci (QTL) mapping. Environ Exp Bot 71:158-165. doi:10.1016/j. envexpbot.2010.11.010

Lockhart JA (1965) An analysis of irreversible plant cell elongation. J Theor Biol 8:264-275

Logsdon SD, Jordahl JL, Karlen DL (1993) Tillage and crop effects on ponded and tension infiltration rates. Soil Till Res 28:179-189. doi: 10.1016/0167-1987(93)90025-K

Lopes MS, Araus JL, Van Heerden PD, Foyer CH (2011) Enhancing drought tolerance in $\mathrm{C}_{4}$ crops. J Exp Bot 62:3135-3153. doi:10. 1093/jxb/err105

Lopes MS, Reynolds MP (2010) Partitioning of assimilates to deeper roots is associated with cooler canopies and increased yield under drought in wheat. Funct Plant Biol 37:147-156. doi:10.1071/ FP09121

Lösch R (1995) Plant water relations. In: Behnke HD, Lüttge U, Esser K, Kadereit JW, Runge M (eds) Progress in botany 56. Springer Berlin Heidelberg, pp 56-65

Loss SP, Siddique KHM, Tennant D (1997) Adaptation of faba bean (Vicia faba L.) to dryland Mediterranean-type environments. III. water use and water-use efficiency. Field Crops Res 54:153-162. doi:10.1016/S0378-4290(97)00042-7

Loveland P, Webb J (2003) Is there a critical level of organic matter in the agricultural soils of temperate regions: a review. Soil Till Res 70:118. doi:10.1016/S0167-1987(02)00139-3

Lynch JP (2013) Steep, cheap and deep: an ideotype to optimize water and $\mathrm{N}$ acquisition by maize root systems. Ann Bot. doi:10.1093/aob/ $\operatorname{mcs} 293$

Ma BL, Dwyer LM, Costa C, Cober ER, Morrison MJ (2001) Early prediction of soybean yield from canopy reflectance measurements. Agron J 93:1227-1234. doi:10.2134/agronj2001.1227

MacRae RJ, Mehuys GR (1985) Effect of green manuring on the physical properties of temperate-area soils. Adv Soil Sci 3:71-94. doi:10. 1007/978-1-4612-5090-6 2

Mahdi L, Bell CJ, Ryan J (1998) Establishment and yield of wheat (Triticum turgidum L.) after early sowing at various depths in a semi-arid Mediterranean environment. Field Crops Res 58:187196. doi:10.1016/S0378-4290(98)00094-X
Manschadi AM, Hammer GL, Christopher JT, deVoil P (2008) Genotypic variation in seedling root architectural traits and implications for drought adaptation in wheat (Triticum aestivum L.). Plant Soil 303:115-129. doi:10.1007/s11104-007-9492-1

Mappa RB, Green RE, Santo L (1986) Temporal variability of soil hydraulic properties with wetting and drying subsequent to tillage. Soil Sci Soc Am J 50:1133-1138. doi:10.2136/sssaj1986. 03615995005000050008x

Maseda PH, Fernández RJ (2006) Stay wet or else: three ways in which plants can adjust hydraulically to their environment. J Exp Bot 57: 3963-3977. doi:10.1093/jxb/erl127

Masri Z, Ryan J (2006) Soil organic matter and related physical properties in a Mediterranean wheat-based rotation trial. Soil Till Res 87:146154. doi:10.1016/j.still.2005.03.003

Maurel C, Verdoucq L, Luu DT, Santoni V (2008) Plant aquaporins: membrane channels with multiple integrated functions. Ann Rev Plant Biol 59:595-624. doi:10.1146/annurev.arplant.59.032607. 092734

McKenzie RH, Middleton AB, Bremer E (2005) Fertilization, seeding date, and seeding rate for malting barley yield and quality in southern Alberta. Can J Plant Sci 85:603-614. doi:10.4141/P04-152

McVay KA, Budde JA, Fabrizzi K, Mikha MM, Rice CW, Schlegel AJ, Peterson DE, Sweeney DW, Thompson C (2006) Management effects on soil physical properties in long-term tillage studies in Kansas. Soil Sci Soc Am J 70:434-438. doi:10.2136/sssaj2005. 0249

Messina CD, Boote KJ, Löffler C, Jones JW, Vallejos CE (2006) Modelassisted genetic improvement of crops. Working with dynamic crop models - evaluation, analysis, parameterization and applications. Elsevier, Amsterdam, pp 309-335

Meyer LD, Dabney SM, Murphree CE, Harmon WC, Grissinger EH (1999) Crop production systems to control erosion and reduce runoff from upland silty soils. T ASAE 42:1645-1652. doi:10.13031/ 2013.13358

Miglierina AM, Iglesias JO, Landriscini MR, Galantini JA, Rosell RA (2000) The effects of crop rotation and fertilization on wheat productivity in the Pampean semiarid region of Argentina. 1. soil physical and chemical properties. Soil Till Res 53:129-135. doi:10.1016/ S0167-1987(99)00096-3

Miller JJ, Sweetland NJ, Chang C (2002) Hydrological properties of a clay loam soil after long-term cattle manure application. J Environ Qual 31:989-996. doi:10.2134/jeq2002.9890

Miralles DJ, Slafer GA (1997) Radiation interception and radiation use efficiency of near-isogenic wheat lines with different height. Euphytica 97:201-208. doi:10.1023/A:1003061706059

Mishra AK, Singh VP (2010) A review of drought concepts. J Hydrol 391:202-216. doi:10.1016/j.jhydrol.2010.07.012

Mitchell J, Singh P, Wallender W, Munk D, Horwath W, Hogan P, Roy R, Hanson B, Wroble J (2012) No-tillage and high-residue practices reduce soil water evaporation. Calif Agr 66:55-61. doi:10.3733/ca. v066n02p55

Mitchell JP, Peters DW, Shennan C (1999) Changes in soil water storage in winter fallowed and cover cropped soils. J Sust Agric 15:19-31. doi:10.1300/J064v15n02 04

Monneveux P, Reynolds MP, Trethowan R, González-Santoyo H, Peña RJ, Zapata F (2005) Relationship between grain yield and carbon isotope discrimination in bread wheat under four water regimes. Eur J Agron 22:231-242. doi:10.1016/j.eja.2004.03.001

Monneveux P, Sanchez C, Beck D, Edmeades GO (2006) Drought tolerance improvement in tropical maize source populations. Crop Sci 46:180-191. doi:10.2135/cropsci2005.04-0034

Monteith JL (1995) Accommodation between transpiring vegetation and the convective boundary layer. J Hydrol 166:251-263. doi:10.1016/ 0022-1694(94)05086-D

Moore AD, Robertson MJ, Routley R (2011) Evaluation of the water use efficiency of alternative farm practices at a range of spatial and 
temporal scales: a conceptual framework and a modelling approach. Agr Sys 104:162-174. doi:10.1016/j.agsy.2010.05.007

Mori M, Inagaki MN (2012) Root development and water-uptake under water deficit stress in drought-adaptive wheat genotypes. Cereal Res Comm 40:44-52. doi:10.1556/CRC.40.2012.1.6

Mori M, Inagaki MN, Inoue T, Nachit MM (2011) Association of root water-uptake ability with drought adaptation in wheat. Cereal Res Comm 39:551-559. doi:10.1556/CRC.39.2011.4.10

Mrabet R, El-Brahli A, Anibat I, Bessam F (2003) No-tillage technology: research review of impacts on soil quality and wheat production in semiarid Morocco. Options Méditérr 60:133-138

Muchow RC (1989) Comparative productivity of maize, sorghum and pearl millet in a semi-arid tropical environment. II: effect of water deficits. Field Crops Res 20:207-219. doi:10.1016/0378-4290(89) 90080-4

Mulumba LN, Lal R (2008) Mulching effects on selected soil physical properties. Soil Till Res 98:106-111. doi:10.1016/j.still.2007.10.011

Munné-Bosch S, Alegre L (2004) Die and let live: leaf senescence contributes to plant survival under drought stress. Funct Plant Biol 31: 203-216. doi:10.1071/FP03236

Munns R (1988) Why measure osmotic adjustment? Funct Plant Biol 15: 717-726. doi:10.1071/PP9880717

Nagel KA, Putz A, Gilmer F, Heinz K, Fischbach A, Pfeifer J, Faget M, Blossfeld S, Ernst M, Dimaki C, Kastenholz B, Kleinert AK, Galinski A, Scharr H, Fiorani F, Schurr U (2012) GROWSCREEN-Rhizo is a novel phenotyping robot enabling simultaneous measurements of root and shoot growth for plants grown in soil-filled rhizotrons. Funct Plant Biol 39:891-904. doi: 10.1071/FP12023

Nakhforoosh A, Adu-Gyamfi J, Bodner G, Grausgruber H (2013) Recent approaches in screening methodology for drought resistance. $\mathrm{CAB}$ Rev 8(047):1-14. doi:10.1079/PAVSNNR20138047

Nakhforoosh A, Grausgruber H, Kaul HP, Bodner G (2014) Wheat root diversity and root functional characterization. Plant Soil 380:211229. doi:10.1007/s11104-014-2082-0

Nguyen C (2003) Rhizodeposition of organic C by plants: mechanisms and controls. Agronomie 23:375-396

Nielsen DC, Vigil MF (2005) Legume green fallow effects on soil water content at wheat. Agron J 97:684-689. doi:10.2134/agronj2004. 0071

Nobel PS (2009) Physicochemical and environmental plant physiology. Academic, San Diego

Nuttall JG, Davies SL, Armstrong RA, Peoples MB (2008) Testing the primer-plant concept: wheat yields can be increased on alkaline sodic soils when an effective primer phase is used. Aust J Agr Res 59:331-338. doi:10.1071/AR07287

Ober ES, Bloa ML, Clark CJ, Royal A, Jaggard KW, Pidgeon JD (2005) Evaluation of physiological traits as indirect selection criteria for drought tolerance in sugar beet. Field Crops Res 91:231-249. doi: 10.1016/j.fcr.2004.07.012

Or D, Lehmann P, Shahraeeni E, Shokri N (2013) Advances in soil evaporation physics - a review. Vadose Zone J 12: doi:10.2136/ vzj2012.0163

Osunbitan JA, Oyedele DJ, Adekalu KO (2005) Tillage effects on bulk density, hydraulic conductivity and strength of a loamy sand soil in southwestern Nigeria. Soil Till Res 82:57-64. doi:10.1016/j.still. 2004.05.007

O'Toole JC, Cruz RT (1980) Response of leaf water potential, stomatal resistance, and leaf rolling to water stress. Plant Physiol 65:428-432. doi:10.1104/pp. 65.3.428

Pagenkemper SK, Peth S, Puschmann DU, Horn R (2013) Effects of rootinduced biopores on pore space architecture investigated with industrial X-ray computed tomography. In: Anderson SH, Hopmans JW (eds) Soil-water-root processes: advances in tomography and imaging. The Soil Science Society of America, Inc., pp 69-96
Pagliai M, Raglione M, Panini T, Maletta M, La Marca M (1995) The structure of two alluvial soils in Italy after 10 years of conventional and minimum tillage. Soil Till Res 34:209-223. doi:10.1016/01671987(95)00471-4

Pagliai M, Vignozzi N, Pellegrini S (2004) Soil structure and the effect of management practices. Soil Till Res 79:131-143. doi:10.1016/j.still. 2004.07.002

Pala M, Ryan J, Zhang H, Singh M, Harris HC (2007) Water-use efficiency of wheat-based rotation systems in a Mediterranean environment. Agr Water Manag 93:136-144. doi:10.1016/j. agwat.2007.07.001

Palm J, Klaus J, van Schaik L, Zehe E, Schröder B (2010) Modelling spatiotemporal distribution patterns of earthworms in order to indicate hydrological soil processes. Geophys Res Abstracts 12, EGU2010-10837-1

Palta JA, Chen X, Milroy SP, Rebetzke GJ, Dreccer MF, Watt M (2011) Large root systems: are they useful in adapting wheat to dry environments? Funct Plant Biol 38:347-354. doi:10.1071/FP11031

Passioura JB (1977) Grain yield, harvest index, and water use of wheat. J Aus Inst Agr Sci 43:117-121

Passioura JB (2002) Review: environmental biology and crop improvement. Funct Plant Biol 29:537-546. doi:10.1071/FP02020

Passioura JB (2006) Increasing crop productivity when water is scarcefrom breeding to field management. Agr Water Manag 80:176-196. doi:10.1016/j.agwat.2005.07.012

Passioura JB (2010) Plant-water relations. In: Encyclopedia of life sciences. DOI: 10.1002/9780470015902.a0001288.pub2

Pekrun C, Pflaum S, Henne U (2011) Was ist über die Wirkung der Stoppelbearbeitung bekannt-wo fehlt es an Daten? Landtechnik 66:108-112

Peñuelas J, Filella I (1998) Visible and near-infrared reflectance techniques for diagnosing plant physiological status. Trends Plant Sci 3:151-156. doi:10.1016/S1360-1385(98)01213-8

Perkons U, Kautz T, Uteau D, Peth S, Geier V, Thomas K, Lütke Holz K, Athmann M, Pude R, Köpke U (2014) Root-length densities of various annual crops following crops with contrasting root systems. Soil Till Res 137:50-57. doi:10.1016/j.still.2013.11.005

Pietola LM (2005) Root growth dynamics of spring cereals with discontinuation of mouldboard ploughing. Soil Till Res 80: doi.org/ 10.1016/j.still.2004.03.001

Pikul JL, Zuzel JF (1994) Soil crusting and water infiltration affected by long-term tillage and residue management. Soil Sci Soc Am J 58: 1524-1530. doi:10.2136/sssaj1994.03615995005800050036x

Potop V, Soukup J (2009) Spatiotemporal characteristics of dryness and drought in the Republic of Moldova. Theor Appl Climatol 96:305318. doi:10.1007/s00704-008-0041-5

Potop V, Türkott L, Kožnarová V (2009) Drought impact on variability crop yields in Central Bohemia. Cereal Res Comm 37:295-304. doi: 10.1556/CRC.37.2009.2.18

Potop V, Türkott L, Kožnarová V, Možný M (2010) Drought episodes in the Czech Republic and their potential effects in agriculture. Theor Appl Climatol 99:373-388. doi:10.1007/s00704-009-0148-3

Premachandra GS, Saneoka H, Kanaya M, Ogata S (1991) Cell membrane stability and leaf surface wax content as affected by increasing water deficits in maize. J Exp Bot 42:167-171. doi:10.1093/jxb/42. 2.167

Preti F, Dani A, Laio F (2010) Root profile assessment by means of hydrological, pedological and above-ground vegetation information for bio-engineering purposes. Ecol Eng 36:305-316. doi:10.1016/j. ecoleng.2009.07.010

Price AH, Steele KA, Gorham J, Bridges JM, Moore BJ, Evans JL, Richardson P, Jones RGW (2002) Upland rice grown in soil-filled chambers and exposed to contrasting water-deficit regimes: I. Root distribution, water use and plant water status. Field Crops Res 76: 11-24. doi:10.1016/S0378-4290(02)00012-6 
Rai KN, Murty DS, Andrews DJ, Bramel-Cox PJ (1999) Genetic enhancement of pearl millet and sorghum for the semi-arid tropics of Asia and Africa. Genome 42:617-628

Ramakrishna A, Tam HM, Wani SP, Long TD (2006) Effect of mulch on soil temperature, moisture, weed infestation and yield of groundnut in northern Vietnam. Field Crops Res 95:115-125. doi:10.1016/j. fcr.2005.01.030

Rampazzo N, Mentler A (2001) Influence of different agricultural land use on soil properties along the Austrian-Hungarian border. Die Bodenkultur 52:89-115

Rao NRC, Talwar HS, Wright GC (2001) Rapid assessment of specific leaf area and leaf nitrogen in peanut (Arachis hypogaea L.) using a chlorophyll meter. J Agron Crop Sci 186:175-182. doi:10.1046/j. 1439-037X.2001.00472.x

Rao NV, Rego TJ, Meinke H, Parsons D, Craufurd PQ, Wani SP Kropff MJ (2011) Long-term evaluation of dryland cropping systems intensification for sustainable production in the semi-arid tropics of India. In: Resilient food systems for a changing world: Proceedings of the 5th World Congress of Conservation Agriculture incorporating 3rd Farming Systems Design Conference, September 2011, Brisbane, Australia, pp 26-29

Rao RN, Udaykumar M, Farquhar GD, Talwar HS, Prasad TG (1995) Variation in carbon isotope discrimination and its relationship to specific leaf area and ribulose-1, 5-bisphosphate carboxylase content in groundnut genotypes. Funct Plant Biol 22:545-551. doi:10. 1071/PP9950545

Rasse DP, Smucker AJ, Santos D (2000) Alfalfa root and shoot mulching effects on soil hydraulic properties and aggregation. Soil Sci Soc Am J 64:725-731. doi:10.2136/sssaj2000.642725x

Rawls WJ, Nemes A, Pachepsky YA (2004) Effect of soil organic carbon on soil hydraulic properties. Dev Soil Sci 30:95-114. doi:10.1016/ S0166-2481(04)30006-1

Rawls WJ, Pachepsky YA, Ritchie JC, Sobecki TM, Bloodworth H (2003) Effect of soil organic carbon on soil water retention. Geoderma 116:61-76. doi:10.1016/S0016-7061(03)00094-6

Rawson HM, Macpherson HG (2000) Managing your crop. irrigated wheat. FAO, Rome

Raza A, Bodner G, Moghaddam A, Ardakani MR, Loiskandl W, Himmelbauer M, Gollner G, Waneck W, Friedel JK (2013) Assessing the effect of lucerne utilization systems in the Pannonian region of Austria. Arch Agron Soil Sci 60:297-311. doi:10.1080/03650340.2013.791972

Reddy BVS, Ramesh S, Reddy PS, Kumar AA (2009) Genetic enhancement for drought tolerance in Sorghum. In: Janick J (ed) Plant breeding reviews 31. Wiley, NJ. doi:10.1002/9780470593783.ch3

Reynolds M, Braun HJ, Pietragalla J, Ortiz R (2007) Challenges to international wheat breeding. Euphytica 157:281-285. doi:10.1007/ s10681-007-9505-4

Reynolds M, Foulkes MJ, Slafer GA, Berry P, Parry MA, Snape JW, Angus WJ (2009) Raising yield potential in wheat. J Exp Bot 60: 1899-1918. doi:10.1093/jxb/erp016

Reynolds M, Tuberosa R (2008) Translational research impacting on crop productivity in drought-prone environments. Curr Opin Plant Biol 11:171-179. doi:10.1016/j.pbi.2008.02.005

Richards RA (2000) Selectable traits to increase crop photosynthesis and yield of grain crops. J Exp Bot 51:447-458. doi:10.1093/jexbot/51. suppl_1.447

Richards RA, Passioura JB (1989) A breeding program to reduce the diameter of the major xylem vessel in the seminal roots of wheat and its effect on grain yield in rain-fed environments. Aust J Agr Res 40:943-950. doi:10.1071/AR9890943

Richards RA, Rebetzke GJ, Condon AG, Van Herwaarden AF (2002) Breeding opportunities for increasing the efficiency of water use and crop yield in temperate cereals. Crop Sci 42:111-121. doi:10. 2135/cropsci2002.1110
Rieger M, Litvin P (1999) Root system hydraulic conductivity in species with contrasting root anatomy. J Exp Bot 50:201-209. doi:10.1093/ $\mathrm{jxb} / 50.331 .201$

Rockström J, Lannerstad M, Falkenmark M (2007) Assessing the water challenge of a new green revolution in developing countries. PNAS 104:6253-6260. doi:10.1073/pnas.0605739104

Rodriguez-Iturbe I, D’Odorico P, Porporato A, Ridolfi L (1999) On the spatial and temporal links between vegetation, climate, and soil moisture. Water Resour Res 35:3709-3722. doi:10.1029/ 1999WR900255

Rodriguez-Iturbe I, Porporato A, Laio F, Ridolfi L (2001) Plants in watercontrolled ecosystems: active role in hydrologic processes and response to water stress. I: scope and general outline. Adv Water Resour 24:695-705. doi:10.1016/S0309-1708(01)00004-5

Rust B, Williams JD s.a. How tillage effects soil erosion and runoff. USDA Technical Note

Ryan J (2011) Rainfed farming systems in the West Asia-North Africa (WANA) Region. In: Tow P, Cooper I, Partridge I, Birch C (eds) Rainfed farming systems. Springer, Netherlands, pp 365-393

Ryser P (2006) The mysterious root length. Plant Soil 286:1-6. doi:10. 1007/s11104-006-9096-1

Sadras VO, Lawson C (2011) Genetic gain in yield and associated changes in phenotype, trait plasticity and competitive ability of South Australian wheat varieties released between 1958 and 2007. Crop Past Sci 62:533-549. doi:10.1071/CP11060

Safriel U, Adeel Z, Niemeijer D, Puigdefabregas J, White R, Lal $\mathrm{R}$, Winslow $\mathrm{M}$, Ziedler $\mathrm{J}$, Prince $\mathrm{S}$, Archer $\mathrm{E}$, King $\mathrm{C}$, Shapiro B, Wessels K, Nielsen T, Portnov B, Reshef I, Thonell J, Lachman E, McNab D (2005) Dryland systems. In: Hassan RM, Scholes R, Ash N (eds) Millennium ecosystem assessment: ecosystems and human well-being: current state and trends: findings of the condition and trends working group. Island Press, Washington, pp 623-662

Samuels L, Kunst L, Jetter R (2008) Sealing plant surfaces: cuticular wax formation by epidermal cells. Annu Rev Plant Biol 59:683-707. doi: 10.1146/annurev.arplant.59.103006.093219

Sánchez FJ, Manzanares M, de Andres EF, Tenorio JL, Ayerbe L (1998) Turgor maintenance, osmotic adjustment and soluble sugar and proline accumulation in 49 pea cultivars in response to water stress. Field Crops Res 59:225-235. doi:10.1016/S0378-4290(98)00125-7

Sandhu KS, Benbi DK, Prihar SS, Saggar S (1992) Dryland wheat yield dependence on rainfall, applied $\mathrm{N}$ and mulching in preceding maize. Fert Res 32:229-237. doi:10.1007/BF01048785

Sanguineti MC, Li S, Maccaferri M, Corneti S, Rotondo F, Chiari T, Tuberosa R (2007) Genetic dissection of seminal root architecture in elite durum wheat germplasm. Ann Appl Biol 151:291-305. doi: 10.1111/j.1744-7348.2007.00198.x

Sárvári M (2005) Impact of nutrient supply, sowing time and plant density on maize yields. Act Agron Hung 53:59-70. doi:10.1556/AAgr. 53.2005 .1 .8

Sasal MC, Andriulo AE, Taboada MA (2006) Soil porosity characteristics and water movement under zero tillage in silty soils in Argentinian Pampas. Soil Till Res 87:9-18. doi:10.1016/j.still.2005.02.025

Schenk HJ, Jackson RB (2002) Rooting depths, lateral root spreads and below-ground/above-ground allometries of plants in water-limited ecosystems. J Ecol 90:480-494. doi:10.1046/j.1365-2745.2002. 00682. X

Scherr SJ, Yadav S (1996) Land degradation in the developing world: implications for food, agriculture and the environment to 2020. IFPRI, Food, Agric. and the Environment Discussion Paper 14, Washington, DC

Schillinger WF (2005) Tillage method and sowing rate relations for dryland spring wheat, barley, and oat. Crop Sci 45:2636-2643. doi:10. 2135/cropsci2005.04-0016

Schmidt MW, Torn MS, Abiven S, Dittmar T, Guggenberger G, Janssens IA, Kleber M, Kögel-Knabner I, Lehmann J, Manning DAC, 
Nannipieri P, Rasse DP, Weiner S, Trumbore SE (2011) Persistence of soil organic matter as an ecosystem property. Nature 478:49-56. doi:10.1038/nature10386

Schuepp PH (1993) Tansley review 59. Leaf boundary layers. New Phytol 125:477-507. doi:10.1111/j.1469-8137.1993.tb03898.x

Schulze ED (1994) The regulation of plant transpiration: interactions of feedforward, feedback, and futile cycles. In: Schulze ED (ed) Flux control in biological systems: from enzymes to populations and ecosystems. Academic, San Diego, pp 203-235

Schutter ME, Dick RP (2002) Microbial community profiles and activities among aggregates of winter fallow and cover-cropped soil. Soil Sci Soc Am J 66:142-153. doi:10.2136/sssaj2002.1420

Schwarte AJ, Gibson LR, Karlen DL, Dixon PM, Liebman M, Jannink JL (2006) Planting date effects on winter triticale grain yield and yield components. Crop Sci 46:1218-1224. doi:10.2135/cropsci2005.060130

Schwärzel K, Carrick S, Wahren A, Feger KH, Bodner G, Buchan G (2011) Soil hydraulic properties of recently tilled soil under cropping rotation compared with two-year pasture. Vadose Zone J 10:354-366. doi:10.2136/vzj2010.0035

Schwen A, Bodner G, Scholl P, Buchan GD, Loiskandl W (2011) Temporal dynamics of soil hydraulic properties and the waterconducting porosity under different tillage. Soil Till Res 113:8998. doi:10.1016/j.still.2011.02.005

Schwinning S, Ehleringer JR (2001) Water use trade-offs and optimal adaptations to pulse-driven arid ecosystems. J Ecol 89:464-480. doi:10.1046/j.1365-2745.2001.00576.x

Sekera F (1943) Gesunder und kranker Boden. Ein praktischer Wegweiser zur Gesunderhaltung des Ackers, Wien

Serraj R, Bidinger FR, Chauhan YS, Seetharama N, Nigam SN, Saxena NP (2003) Management of drought in ICRISAT cereal and legume mandate crops. In: Kijne JW, Barker R, Molden D (eds) Water productivity in agriculture: limits and opportunities for improvement. CABI Publishing, Wallingford, pp 127-144

Serraj R, Sinclair TR (2002) Osmolyte accumulation: can it really help increase crop yield under drought conditions? Plant Cell Environ 25: 333-341. doi:10.1046/j.1365-3040.2002.00754.x

Sharp RE, Davies WJ (1985) Root growth and water uptake by maize plants in drying soil. J Exp Bot 36:1441-1456. doi:10.1093/jxb/36. 9.1441

Sharratt BS, McWilliams DA (2005) Microclimatic and rooting characteristics of narrow-row versus conventional-row corn. Agron J 97: 1129-1135. doi:10.2134/agronj2004.0292

Shaver TM, Peterson GA, Ahuja LR, Westfall DG, Sherrod LA, Dunn G (2002) Surface soil physical properties after twelve years of dryland no-till management. Soil Sci Soc Am J 66:1296-1303. doi:10.2136/ sssaj2002.1296

Shearman VJ, Sylvester-Bradley R, Scott RK, Foulkes MJ (2005) Physiological processes associated with wheat yield progress in the UK. Crop Sci 45:175-185. doi:10.2135/cropsci2005.0175

Sheffield J, Wood EF (2008) Projected changes in drought occurrence under future global warming from multi-model, multi-scenario, IPCC AR4 simulations. Clim Dyn 13:79-105. doi:10.1007/ s00382-007-0340-Z

Shepherd T, Wynne Griffiths D (2006) The effects of stress on plant cuticular waxes. New Phytol 171:469-499. doi:10.1111/j.14698137.2006.01826.x

Sheshshayee MS, Bindumadhava H, Rachaputi NR, Prasad TG, Udayakumar M, Wright GC, Nigam SN (2006) Leaf chlorophyll concentration relates to transpiration efficiency in peanut. Ann Appl Biol 148:7-15. doi:10.1111/j.1744-7348.2005.00033.x

Shirani H, Hajabbasi MA, Afyuni M, Hemmat A (2002) Effects of farmyard manure and tillage systems on soil physical properties and corn yield in central Iran. Soil Till Res 68:101-108. doi:10.1016/S01671987(02)00110-1
Sial MA, Dahot MU, Arain MA, Laghari KA, Mangrio SM, Mangan BN (2008) Evaluation of wheat mutant lines for yield and yield components under different sowing dates. Pak J Biotechnol 5:27-38

Siddique KHM, Belford RK, Tennant D (1990a) Root: shoot ratios of old and modern, tall and semi-dwarf wheats in a Mediterranean environment. Plant Soil 121:89-98. doi:10.1007/BF00013101

Siddique KHM, Tennant D, Perry MW, Belford RK (1990b) Water use and water use efficiency of old and modern wheat cultivars in a Mediterranean-type environment. Aust J Agric Res 41:431-447. doi:10.1071/AR9900431

Silim SN, Saxena MC (1993) Yield and water use efficiency of faba bean sown at two row spacings and seed densities. Exp Agr 29:173-181. doi:10.1017/S0014479700020615

Simmonds LP, Williams JH (1989) Population, water use and growth of groundnut maintained on stored water. II: transpiration and evaporation from soil. Exp Agr 25:63-75. doi:10.1017/ S0014479700016458

Singh BR, Singh DP (1995) Agronomic and physiological responses of sorghum, maize and pearl millet to irrigation. Field Crops Res 42: 57-67. doi:10.1016/0378-4290(95)00025-L

Singh M, Srivastava JP, Kumar A (1992) Cell membrane stability in relation to drought tolerance in wheat genotypes. J Agron Crop Sci 168:186-190. doi:10.1111/j.1439-037X.1992.tb00997.x

Sinkevičienė A, Jodaugienė D, Pupalienė R, Urbonienè M (2009) The influence of organic mulches on soil properties and crop yield. Agron Res 7:485-491

Six J, Bossuyt H, Degryze S, Denef K (2004) A history of research on the link between (micro) aggregates, soil biota, and soil organic matter dynamics. Soil Till Res 79:7-31. doi:10.1016/j.still.2004.03.008

Slafer GA, Araus JL, Royo C, Moral LFG (2005) Promising ecophysiological traits for genetic improvement of cereal yields in Mediterranean environments. Ann Appl Biol 146:61-70. doi:10. 1111/j.1744-7348.2005.04048.x

Slafer GA, Araus JR (2007) Physiological traits for improving wheat yield under a wide range of conditions. In: Spiertz HJ, Struik PC, van Laar HH (eds) Scale and complexity in plant systems research: gene-plant-crop relations. Springer, The Netherlands, pp 147-156

Slayter RO (1967) Plant-water relationships. Academic, New York

Sperry JS (2003) Evolution of water transport and xylem structure. Int J Plant Sci 164:S115-S127

Sperry JS (2004) Coordinating stomatal and xylem functioning - an evolutionary perspective. New Phytol 162:568-570. doi:10.1111/j. 1469-8137.2004.01072.x

Sperry JS, Adler FR, Campbell GS, Comstock JP (1998) Limitation of plant water use by rhizosphere and xylem conductance: results from a model. Plant Cell Environ 21:347-359. doi:10.1046/j.1365-3040. 1998.00287.x

Sperry JS, Hacke UG, Oren R, Comstock JP (2002) Water deficits and hydraulic limits to leaf water supply. Plant Cell Environ 25:251263. doi:10.1046/j.0016-8025.2001.00799.x

Sposito G (2013) Green water and global food security. Vadose Zone J. 12, doi:10.2136/vzj2013.02.0041

Steduto P, Hsiao TC, Fereres E (2007) On the conservative behavior of biomass water productivity. Irrigation Sci 25:189-207. doi:10.1007/ s00271-007-0064-1

Steiner JL (1994) Crop residue effects on water conservation. In: Unger PW (ed) Managing a agricultural residues. CRC Press, Boca Raton, pp 41-76

Stern R, Laker MC, Vandermerwe AJ (1991) Field studies on effect of soil conditioners and mulch on runoff from kaolinitic and illitic soils. Soil Res 29:249-261. doi:10.1071/SR9910249

Steudle E (2000) Water uptake by roots: effects of water deficit. J Exp Bot 51:1531-1542. doi:10.1093/jexbot/51.350.1531

Steudle E, Peterson CA (1998) How does water get through roots? J Exp Bot 49:775-788. doi:10.1093/jxb/49.322.775 
Stirzaker RJ, Passioura JB, Wilms A (1996) Soil structure and plant growth: impact of bulk density and biopores. Plant Soil 185:151162. doi:10.1007/BF02257571

Středa T, Dostál V, Horáková V, Chloupek O (2012) Effective use of water by wheat varieties with different root system sizes in rainfed experiments in Central Europe. Agr Water Manag 104:203209. doi:10.1016/j.agwat.2011.12.018

Strudley MW, Green TR, Ascough JC II (2008) Tillage effects on soil hydraulic properties in space and time: state of the science. Soil Till Res 99:4 48. doi:10.1016/j.still.2008.01.007

Sturz AV, Carter MR, Johnston HW (1997) A review of plant disease, pathogen interactions and microbial antagonism under conservation tillage in temperate humid agriculture. Soil Till Res 41:169-189. doi:10.1016/S0167-1987(96)01095-1

Swaminathan MS (2006) An evergreen revolution. Crop Sci 46:22932303. doi:10.2135/cropsci2006.9999

Tardieu F (2012) Any trait or trait-related allele can confer drought tolerance: just design the right drought scenario. J Exp Bot 63:25-31. doi:10.1093/jxb/err269

Tardieu F, Davies WJ (1993) Integration of hydraulic and chemical signalling in the control of stomatal conductance and water status of droughted plants. Plant Cell Environ 16:341-349. doi:10.1111/j. 1365-3040.1993.tb00880.x

Tardieu F, Simonneau T (1998) Variability among species of stomatal control under fluctuating soil water status and evaporative demand: modelling isohydric and anisohydric behaviours. J Exp Bot 49:419 432. doi:10.1093/jxb/49.Special_Issue.419

Tebrügge F, Düring RA (1999) Reducing tillage intensity — a review of results from a long-term study in Germany. Soil Till Res 53:15-28. doi:10.1016/S0167-1987(99)00073-2

Thomson BD, Siddique KHM, Barr MD, Wilson JM (1997) Grain legume species in low rainfall Mediterranean-type environments. I: phenology and seed yield. Field Crops Res 54:173-187. doi:10. 1016/S0378-4290(97)00047-6

Tisdall JM, Oades J (1982) Organic matter and water-stable aggregates in soils. J Soil Sci 33:141-163. doi:10.1111/j.1365-2389.1982. tb01755.x

Tokatlidis IS, Koutroubas SD (2004) A review of maize hybrids' dependence on high plant populations and its implications for crop yield stability. Field Crops Res 88:103-114. doi:10.1016/j.fcr.2003.11.013

Tollenaar M, Lee EA (2002) Yield potential, yield stability and stress tolerance in maize. Field Crops Res 75:161-169. doi:10.1016/ S0378-4290(02)00024-2

Tollenaar M, Wu J (1999) Yield improvement in temperate maize is attributable to greater stress tolerance. Crop Sci 39:1597-1604. doi:10.2135/cropsci1999.3961597x

Tompkins DK, Fowler DB, Wright AT (1991) Water use by no-till winter wheat influence of seed rate and row spacing. Agron J 83:766-769. doi:10.2134/agronj1991.00021962008300040022x

Trachsel S, Messmer R, Stamp P, Hund A (2009) Mapping of QTLs for lateral and axile root growth of tropical maize. Theor Appl Genet 119:1413-1424. doi:10.1007/s00122-009-1144-9

Traoré O, Groleau-Renaud V, Plantureux S, Tubeileh A, Boeuf-Tremblay V (2000) Effect of root mucilage and modelled root exudates on soil structure. Eur J Soil Sci 51:575-581. doi:10.1046/j.1365-2389. 2000.00348.x

Trethowan RM, Mujeeb-Kazi A (2008) Novel germplasm resources for improving environmental stress tolerance of hexaploid wheat. Crop Sci 48:1255-1265. doi:10.2135/cropsci2007.08.0477

Trethowan RM, van Ginkel M, Rajaram S (2002) Progress in breeding wheat for yield and adaptation in global drought affected environments. Crop Sci 42:1441-1446. doi:10.2135/cropsci2002.1441

Tripathy JN, Zhang J, Robin S, Nguyen TT, Nguyen HT (2000) QTLs for cell-membrane stability mapped in rice (Oryza sativa L.) under drought stress. Theor Appl Genet 100:1197-1202. doi:10.1007/ s001220051424
Tron S, Laio F, Ridolfi L (2012) Plant water uptake strategies to cope with stochastic rainfall. Adv Water Res 53:118-130. doi:10.1016/j. advwatres.2012.10.007

Turner NC (2004) Sustainable production of crops and pastures under drought in a Mediterranean environment. Ann Appl Biol 144:139 147. doi:10.1111/j.1744-7348.2004.tb00327.x

Turner NC, Abbo S, Berger JD, Chaturvedi SK, French RJ, Ludwig C, Mannur DM, Singh SJ, Yadava HS (2007) Osmotic adjustment in chickpea (Cicer arietinum L.) results in no yield benefit under terminal drought. J Exp Bot 58:187-194. doi:10.1093/jxb/erl192

Tuzet A, Perrier A, Leuning R (2003) A coupled model of stomatal conductance, photosynthesis and transpiration. Plant Cell Environ 26:1097-1116. doi:10.1046/j.1365-3040.2003.01035.x

Tyree MT (1997) The cohesion-tension theory of sap ascent: current controversies. J Exp Bot 48:1753-1765. doi:10.1093/jxb/48.10.1753

Tyree MT, Sperry JS (1989) Vulnerability of xylem to cavitation and embolism. Ann Rev Plant Biol 40:19-36. doi:10.1146/annurev.pp. 40.060189.000315

Udayakumar M, Sheshshayee MS, Nataraj KN, Bindumadhava H, Devendra R, Aftab Hussain IS, Prasad TG (1998) Why breeding for water use efficiency has not been successful? An analysis and alternate approach to exploit this trait for crop improvement. Current Sci 74:994-1000

UNESCO (2012) Managing water under uncertainty and risk. UN World Water Development Report 4, Paris

Unger PW, Stewart BA, Parr JF, Singh RP (1991) Crop residue management and tillage methods for conserving soil and water in semi-arid regions. Soil Till Res 20:219-240. doi:10.1016/0167-1987(91) 90041-U

Vadez V, Krishnamurthy L, Kashiwagi J, Kholova J, Devi JM, Sharma K (2007) Exploiting the functionality of root systems for dry, saline, and nutrient deficient environments in a changing climate. $\mathrm{J}$ Semiarid Trop Agric Res 4, www.icrisat.cgiar.org/Journal/ SpecialProject/sp10.pdf

Valentovic P, Luxova M, Kolarovic L, Gasparikova O (2006) Effect of osmotic stress on compatible solutes content, membrane stability and water relations in two maize cultivars. Plant Soil Environ 52: 186-191

Van Ginkel M, Calhoun DS, Gebeyehu G, Miranda A, Tian-you C, Pargas Lara R, Trethowan RM, Sayre K, Crossa J, Rajaram S (1998) Plant traits related to yield of wheat in early, late, or continuous drought conditions. Euphytica 100:109-121. doi:10.1023/ A: 1018364208370

Van Oosterom EJ, Mahalakshmi V, Bidinger FR, Rao KP (1996) Effect of water availability and temperature on the genotype-by-environment interaction of pearl millet in semi-arid tropical environments. Euphytica 89:175-183. doi:10.1007/BF00034603

Verhulst N, Nelissen V, Jespers N, Haven H, Sayre KD, Raes D, Deckers J, Govaerts B (2011) Soil water content, maize yield and its stability as affected by tillage and crop residue management in rainfed semiarid highlands. Plant Soil 344:73-85. doi:10.1007/s11104-0110728-8

Vidal M, López A (2005) Cover crops and organic amendments to prevent nitrate contamination under a wet climate. Agron Sustain Dev 25:455-463. doi:10.1051/agro:2005043

Villamil MB, Bollero GA, Darmody RG, Simmons FW, Bullock DG (2006) No-till corn/soybean systems including winter cover crops. Soil Sci Soc Am J 70:1936-1944. doi:10.2136/sssaj2005.0350

Waines JG, Ehdaie B (2007) Domestication and crop physiology: roots of green-revolution wheat. Ann Bot 100:991-998. doi:10.1093/aob/ $\mathrm{mcm} 180$

Wallace JS (2000) Increasing agricultural water use efficiency to meet future food production. Agr Ecosys Environ 82:105-119. doi:10. 1016/S0167-8809(00)00220-6

Waloszczyk K (1991) Ergebnisse zur Ertragsbildung bei ökologisch orientiertem Winterweizenanbau auf Lößschwarzerdeböden in 
trockenen Lagen. J Agron Crop Sci 166:238-248. doi:10.1111/j. 1439-037X.1991.tb00910.x

Ward PR, Flower KC, Cordingley N, Weeks C, Micin SF (2012) Soil water balance with cover crops and conservation agriculture in a Mediterranean climate. Field Crops Res 132:33-39. doi:10.1016/j. fcr.2011.10.017

Wasson AP, Richards RA, Chatrath R, Misra SC, Prasad SS, Rebetzke GJ, Kirkegaard JA, Christopher J, Watt M (2012) Traits and selection strategies to improve root systems and water uptake in waterlimited wheat crops. J Exp Bot 63:3485-3498. doi:10.1093/jxb/ ers 111

Wasson AP, Rebetzke GJ, Kirkegaard JA, Christopher J, Richards RA, Watt M (2014) Soil coring at multiple field environments can directly quantify variation in deep root traits to select wheat genotypes for breeding. J Exp Bot. doi:10.1093/jxb/eru250

Westgate ME, Boyer JS (1985) Osmotic adjustment and the inhibition of leaf, root, stem and silk growth at low water potentials in maize. Planta 164:540-549. doi:10.1007/BF00395973

White RG, Kirkegaard JA (2010) The distribution and abundance of wheat roots in a dense, structured subsoil - implications for water uptake. Plant Cell Environ 33:133-148. doi:10.1111/j.1365-3040. 2009.02059.x

Williams SM, Weil RR (2004) Crop cover root channels may alleviate soil compaction effects on soybean crop. Soil Sci Soc Am J 68: 1403-1409. doi:10.2136/sssaj2004.1403

Winterhalter L, Mistele B, Jampatong S, Schmidhalter U (2011) High throughput phenotyping of canopy water mass and canopy temperature in well-watered and drought stressed tropical maize hybrids in the vegetative stage. Eur J Agron 35:22-32. doi:10.1016/j.eja.2011.03.004

Worland AJ (1996) The influence of flowering time genes on environmental adaptability in European wheats. Euphytica 89:49-57. doi: 10.1007/BF00015718

World Meteorological Organization (1992) International Meteorological Vocabulary. 2nd ed

Wuest SB (2001) Soil biopore estimation: effects of tillage, nitrogen, and photographic resolution. Soil Till Res 62:111-116. doi:10.1016/ S0167-1987(01)00218-5

Xue L, Cao W, Luo W, Dai T, Zhu Y (2004) Monitoring leaf nitrogen status in rice with canopy spectral reflectance. Agron J 96:135-142. doi:10.2134/agronj2004.1350

Yadav OP, Rai KN, Gupta SK (2012) Pearl millet: genetic improvement for tolerance. In: Tuteja N, Gill SS, Tuteja R (eds) Improving crop productivity in sustainable agriculture. Wiley-Blackwell, Winheim, Germany, pp 261-288
Yang D, Kanae S, Oki T, Koike T, Musiake K (2003) Global potential soil erosion with reference to land use and climate changes. Hydrol Process 17:2913-2928. doi:10.1002/hyp.1441

Young IM, Crawford JW (2004) Interactions and self-organization in the soil-microbe complex. Science 304:1634-1637. doi:10.1126/ science.1097394

Yunusa IAM, Mele PM, Rab MA, Schefe CR, Beverly CR (2002) Priming of soil structural and hydrological properties by native woody species, annual crops, and a permanent pasture. Soil Res 40:207-219. doi:10.1071/SR01038

Yunusa IAM, Newton PJ (2003) Plants for amelioration of subsoil constraints and hydrological control: the primer-plant concept. Plant Soil 257:261-281. doi:10.1023/A:1027381329549

Yunusa IAM, Sedgley RH, Siddique KMH (1994) Influence of mulching on the pattern of growth and water use by spring wheat and moisture storage on a fine textured soil. Plant Soil 160:119-130. doi:10.1007/ BF00150353

Zaman-Allah M, Jenkinson DM, Vadez V (2011) Chickpea genotypes contrasting for seed yield under terminal drought stress in the field differ for traits related to the control of water use. Funct Plant Biol 38:270-281. doi:10.1071/FP10244

Zaongo CGL, Wendt CW, Lascano RJ, Juo ASR (1997) Interactions of water, mulch and nitrogen on sorghum in Niger. Plant Soil 197:119 126. doi:10.1023/A:1004244109990

Zegada-Lizarazu W, Iijima M (2005) Deep root water uptake ability and water use efficiency of pearl millet in comparison to other millet species. Plant Prod Sci 8:454-460. doi:10.1626/ pps.8.454

Zeiger E, Farquhar GD, Cowan IR (1987) Stomata function. Standford University Press, California

Zlatev ZS, Lidon FC, Ramalho JC, Yordanov IT (2006) Comparison of resistance to drought of three bean cultivars. Biol Plantarum 50: 389-394. doi:10.1007/s10535-006-0054-9

Zogg GP, Zak DR, Ringelberg DB, White DC, MacDonald NW, Pregitzer KS (1997) Compositional and functional shifts in microbial communities due to soil warming. Soil Sci Soc Am J 61:475-481. doi: 10.2136/sssaj1997.03615995006100020015x

Zuazo VHD, Pleguezuelo CRR (2008) Soil-erosion and runoff prevention by plant covers. A review. Agron Sustain Dev 28:65-86. doi: 10.1051/agro:2007062

Zwieniecki MA, Holbrook NM (2009) Confronting Maxwell's demon: biophysics of xylem embolism repair. Trends Plant Sci 14:530-534. doi:10.1016/j.tplants.2009.07.002 